\title{
MIRADAS A LOS CONJUNTOS HISTÓRICOS EN GALICIA. ANTECEDENTES PARA LA PERCEPCIÓN DEL PAISAJE URBANO COMO PATRIMONIO*
}

\author{
Data recepción: 2013/06/20 \\ Data aceptación: 2013/10/04 \\ Contacto autor: jesusangel.sanchez@usc.es
}

\author{
Jesús Ángel Sánchez García \\ Universidade de Santiago de Compostela
}

\section{RESUMEN}

Este artículo examina el camino hacia la percepción patrimonial del paisaje urbano en el contexto de la modernización de las ciudades gallegas durante los siglos XIX y XX. La aplicación de las estrategias de renovación urbana decimonónicas, sobre todo con la ampliación y alineación de calles, combinada con la irrupción de los edificios eclécticos y modernistas, originó las primeras miradas señalando el riesgo de pérdida de los elementos típicos en las viejas ciudades. La investigación plantea una aproximación cualitativa, combinando documentos de archivo con textos periodísticos de escritores gallegos como Emilia Pardo Bazán o Antonio Rey Soto. La difusión de estas preocupaciones tuvo su efecto en las primeras medidas y regulaciones adoptadas por arquitectos -Mariano Fernández Ragel, Constantino Candeira, José María Banet-y políticos -Manuel Villar Iglesias, José M. Díaz Varela, Fermín Zelada- para procurar la preservación de los conjuntos históricos como patrimonio.

Palabras clave: urbanismo, patrimonio, conjuntos históricos, paisaje urbano, Galicia

\section{ABSTRACT}

This paper examines some of the ways in which the urban landscape was perceived in the context of $19^{\text {th }}$ and $20^{\text {th }}$ century Galician cities' modernization process. The application of urban renovation strategies, mainly widening and alignment of streets, combined with the appearance of the eclectic and Art Nouveau buildings is seen as deeply interconnected with the origin of the first gazes noticing the risk of loss for the typical elements in the historic cities. The research takes a qualitative approach by combining archive documents with journalistic texts of some Galician writers -Emilia Pardo Bazán, Antonio Rey Soto. The extension of these concerns was received in the first proposals and regulations took by architects -Mariano Fernández Ragel, Constantino Candeira, José María Banet- and politicians -Manuel Villar Iglesias, José M. Díaz Varela, Fermín Zelada-, towards the preservation of the historic cities as heritage.

Keywords: town planning, heritage, historic cities, urban landscape, Galicia

Parece obvio suponer que, atendiendo a sus excepcionales valores, la protección del patrimonio urbano tuviera para el ámbito de Galicia un hito ineludible en la ciudad de Santiago de Compostela, tal como se plasmó con su declaración como "Monumento Histórico-Artístico", aprobada mediante un decreto del 9 de marzo de $1940^{1}$. Pese a que la terminología recurriera todavía a la añeja categoría de monumento, por su objetivo y ámbito de aplicación esta protección debe equipararse con la actual de "Conjunto histórico", vigente desde las leyes del Patrimonio Histórico Español de 1985 y del Patrimonio Cultural de Galicia de 1995². Lo más relevante es que esta declaración fue la primera aprobada en España para proteger una ciudad histórica, compartida con la ciudad de Toledo que también se incluía en el mismo decreto, con lo que se hermanaban dos monumentales y rancias ciudades presididas por las imágenes de 
muerte y eternidad que, por ejemplo, ya reconociera Valle-Inclán ${ }^{3}$. En la estela de lo dispuesto en la Ley del Tesoro Artístico Nacional de 19334, el decreto argumentaba que, al margen de los edificios singulares ya protegidos como monumentos ${ }^{5}$, el Estado debía promover "la conservación de cuanto tienda a la exaltación de los valores estéticos de las ciudades, a la conservación de lo peculiar y a la permanencia de todo aquello que pueda evocar un hecho, un estilo, un sentimiento". Traduciendo esta necesidad a instrumentos legales, además de lo contemplado en la Ley Municipal vigente desde octubre de $1935^{6}$, se resolvió aprobar esta nueva norma, fundamentada sobre los valores estéticos y de representatividad, tanto histórica como de los posibles rasgos típicos, e incluso sentimentales, de ambas ciudades (Fig. 1).

La elección de Santiago de Compostela y Toledo concordaba desde luego en reconocer y afirmar "lo característico de sus ordenaciones urbanas", es decir, la persistencia de unos trazados que servían de soporte y sentido para un excepcional conjunto de edificaciones histó- ricas. El texto justificativo del decreto no se detenía ahí, ya que, de acuerdo con el contexto nacionalista imperante en los inicios del nuevo régimen, a continuación se afirmaba otro tipo de valor como "recuerdo de la historia patria", es decir, la capacidad para simbolizar o encarnar unas determinadas construcciones ideológicas. Así, la designación de Toledo encerraba un evidente mensaje nacional-católico por la intención de abordar a todos los niveles la rehabilitación de una ciudad que ostentaba el rango de catedral primada de España, pero que había sido especialmente "martirizada" durante la Guerra Civil7. En el caso de Santiago de Compostela, la yuxtaposición de contenidos religiosos y políticos al servicio de la propaganda del régimen todavía era mayor, como se había demostrado ya durante la contienda, cuando Franco restauró la festividad del 25 de julio como Patrón de España, por un decreto del año 1937 que también recuperó la Ofrenda Nacional suprimida por el gobierno de la II República en $1931^{8}$.

Lo cierto es que la instrumentalización política de las tradiciones religiosas vinculadas con el

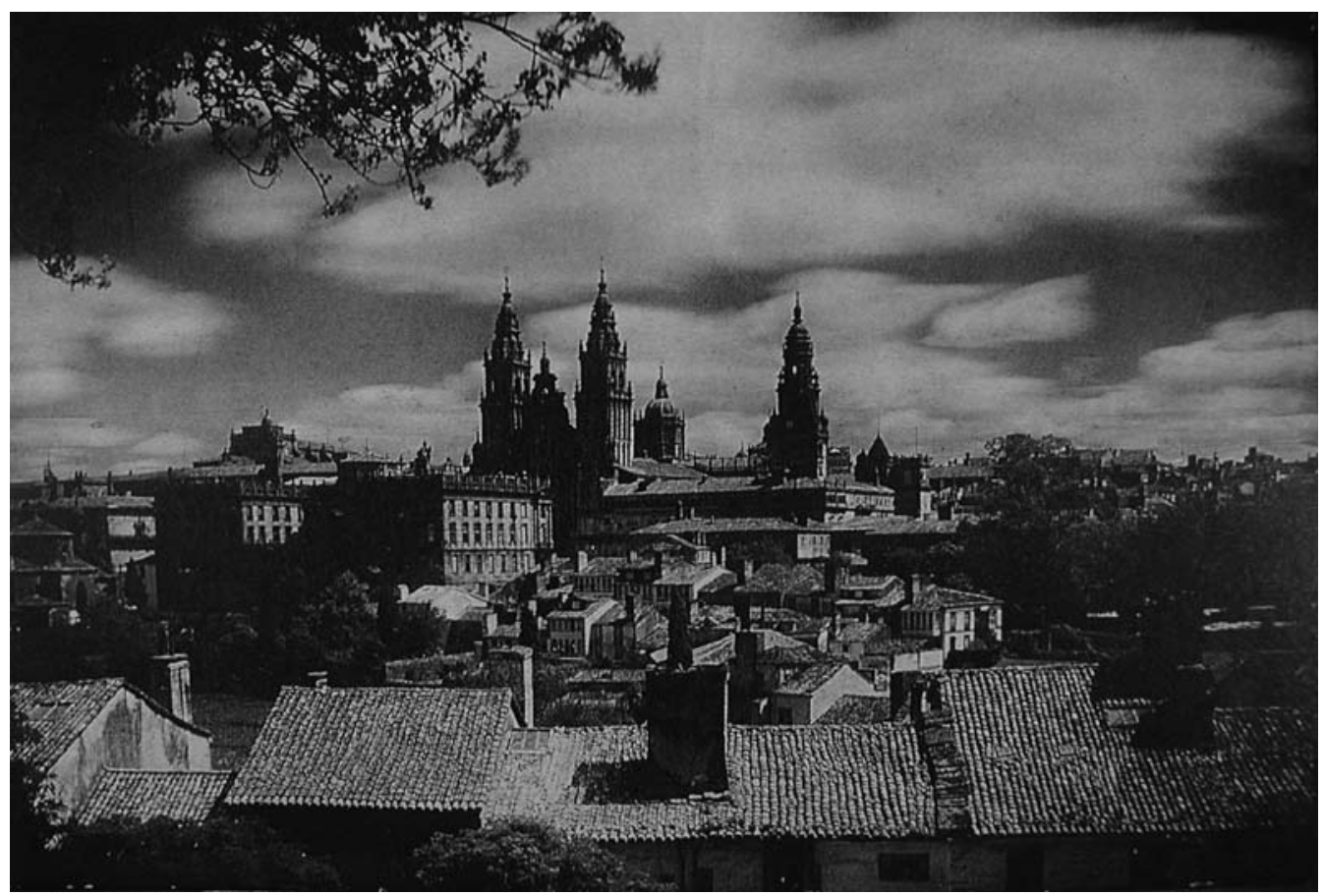

Fig. 1. Vista de Santiago de Compostela en 1936 (Ksado, Estampas de Galicia, 1936) 
origen de Compostela como santuario y hecho urbano se había intensificado durante los años de la Guerra Civil. Una buena prueba radica en lo ocurrido el 30 de agosto de 1936, cuando la urna que contenía las reliquias del Apóstol recorrió en solemne procesión de rogativa las principales calles y plazas del casco viejo para implorar su protección al bando Nacional en la lucha contra el "marxismo y la masonería"9. El propio Franco haría gala de esta supuesta intercesión del Apóstol durante la presentación de la ofrenda de España en julio de 1954, afirmando que su ayuda fue decisiva, entre otros "hechos portentosos" de la guerra, para obtener la victoria en la batalla de Brunete, cuya resolución coincidió precisamente con su festividad ${ }^{10}$.

Incorporando todos estos enmarañados ingredientes políticos e ideológicos, la tutela legal establecida para Santiago de Compostela y Toledo a partir de 1940 debe interpretarse, ya para el ámbito más general de la evolución de las ciudades españolas, como la apertura de una nueva etapa en lo que a la conservación de los conjuntos históricos urbanos se refiere. Con sus limitaciones terminológicas y argumentativas, se iniciaba entonces una dinámica de protección e intervención que venía a clausurar las titubeantes miradas y contradictorias actuaciones producidas décadas atrás, desde finales del siglo XIX, cuando sólo una minoría de intelectuales y técnicos habían comenzado a plantear una nueva percepción de los valores patrimoniales reunidos en los conjuntos urbanos.

\section{Los límites para la mirada al patrimonio urbano y las prioridades de la moderniza- ción}

Al igual que en el resto de Europa occidental, la estimación de los conjuntos urbanos de Galicia como patrimonio, o, lo que es lo mismo, su consideración como una entidad autónoma y merecedora de una figura específica de protección, se vio sujeta a las limitaciones de la mirada romántica por la prioridad otorgada a los monumentos en su dimensión de recordatorios y documentos históricos ${ }^{11}$. Cuando a partir del año 1844 comenzó en España el proceso de selección y declaración de "Monumentos nacionales", una vez superada la etapa de mayores expolios derivados de la desamortización y el ambiente anticlerical ${ }^{12}$, la protección del patrimonio se identificó prioritariamente con ciertos edificios singulares, seleccionados por su valor testimonial en relación con el desarrollo de la historia o el arte nacionales, exacerbando hasta tal grado esa versión del culto al monumento que incluso se ignoraron su entorno y naturaleza urbana ${ }^{13}$. De este modo, la conceptualización del patrimonio urbano como otra vertiente del legado histórico tuvo que esperar hasta que, ya a partir de los primeros años del siglo XX, los efectos combinados de las intervenciones de modernización urbana y la sustitución de piezas arquitectónicas afectaran al paisaje de nuestras viejas ciudades hasta estimular la sensibilidad sobre el problema de su conservación.

Françoise Choay apuntó en su momento a la escala y complejidad de la ciudad, junto a las limitaciones en los instrumentos catastrales y de representación gráfica, como factores que pudieron limitar y frenar esta percepción del patrimonio urbano ${ }^{14}$. Sin negar su peso, no es menos cierto que los mismos planos manejados para comprender y ordenar las ciudades, desde las primeras cartografías urbanas de época Moderna a las más perfeccionadas que podían emplearse a mediados del XIX, coinciden a la hora de mostrar un tipo de visión reducida a las preocupaciones defensivas o a la regularización de trazados viarios $^{15}$. De ahí que para que se abriese paso otro tipo de valoración, que superara la bidimensionalidad del planeamiento técnico y se extendiera a reconocer el interés del conjunto de lo construido en su volumetría histórica y artística fuera precisa otra mirada: la mirada de paseantes, eruditos y connoisseurs que, en el caso de las personas con sensibilidad y formación, brindó una oportunidad para las primeras apreciaciones de lo que hoy entendemos como paisaje urbano ${ }^{16}$.

Como otra limitación para la mirada hacia los conjuntos urbanos es importante señalar que, frente a los valores de antigüedad, identidad, históricos y artísticos reconocidos a los monumentos ${ }^{17}$, el resto de edificaciones presentes en las viejas ciudades, sobre todo las domésticas, no fueron merecedoras de esta misma atención. Ignorando algunas posturas surgidas en el ámbito anglosajón, trasladadas a las líneas 
que John Ruskin y William Morris redactaron sobre la estructura de las ciudades antiguas y el interés de las viviendas más modestas ${ }^{18}$, el panorama erudito en la España del siglo XIX fue ajeno a estas preocupaciones, ya que tanto las viviendas heredadas de tiempos pasados ${ }^{19}$ como las más modernas edificaciones residenciales se consideraron como unas arquitecturas fundamentalmente utilitarias y carentes de calidad artística ${ }^{20}$. Ampliando la profundidad de enfoque hacia la panorámica que ofrecían nuestras viejas ciudades, las connotaciones de decadencia y abandono pesaron decisivamente sobre esta negativa visión de una arquitectura "menor", en un contexto en el que estaban naciendo arquetipos como el de la "ciudad muerta" por falta de energía social y económica² ${ }^{21}$.

Por otra parte, la dinámica de sustitución y reemplazo de las edificaciones residenciales influyó también sobre estas limitaciones para una visión patrimonial, ya que los inmuebles domésticos construidos durante los siglos del barroco, los dominantes en todas las viejas ciudades españolas, no podían todavía, en razón de la peyorativa valoración hacia su estilo, ser admitidos en el mismo plano de importancia que los principales monumentos ${ }^{22}$. De acuerdo con el orden cronológico en el que fueron protegidos en Galicia hasta 1936, al repasar la lista de los monumentos en ámbito urbano se detecta un abrumador predominio de las muestras de arquitectura religiosa medieval, mientras que entre los monumentos civiles apenas puede señalarse un puñado de construcciones, de tipologías y épocas muy variadas: muralla y termas romanas de Lugo, palacio de los condes de Andrade en Pontedeume -derribado entre 1932-1935-, Hospital Real de Santiago, o los palacios episcopales de Santiago y Orense. Este reducido interés por la arquitectura civil, con nula representación de viviendas que no tuvieran la categoría de palacios, añadía otra limitación más para que se llegara a avanzar hacia la apreciación del carácter pintoresco de ciertos enclaves urbanos, de acuerdo con los planteamientos estéticos que derivaban del siglo XVIII; por el contrario, estos conjuntos a los que no se reconocía un valor histórico eran vistos desde la pragmática mentalidad burguesa como una realidad sacrificable ante las exigencias del progreso.
La prioridad otorgada a los monumentos y la falta de capacidad o interés para abarcar otras dimensiones de los conjuntos urbanos ayudan a comprender el desamparo de las viejas ciudades frente a las estrategias de renovación más admiradas durante la segunda mitad del siglo XIX, aquellas que postulaban la necesidad de eliminar partes contrarias a la higiene y obsoletas para las modernas demandas de movilidad, beneficio económico, e incluso estética. La drástica intervención de cirugía urbana ideada y dirigida por el barón Haussmann en el París del II Imperio, con la aplicación a gran escala de los percements para sanar el organismo enfermo de una gran capital, activando la circulación en su interior, evidenció esta negación de cualquier valor tanto para los trazados viarios como para el conjunto de edificaciones residenciales reunidas con el paso de los siglos ${ }^{23}$. La metamorfosis urbana resultante no descuidó los imperativos del culto a los monumentos que sí valía la pena conservar, despejando su entorno o disponiéndolos para la contemplación desde las perspectivas más favorecedoras ${ }^{24}$. El modelo de arrasamiento y sustitución de un tejido urbano de Haussmann se extendió por toda Europa, afortunadamente con operaciones de alcance más reducido, pero cuya resonancia como emblema de una radical e inaplazable modernidad alcanzó hasta las urbes de mediano y pequeño tamaño. En ese ámbito local, los anhelos de renovación defendidos por la burguesía en el poder se convirtieron así en la fuerza motora para encarar, sin remordimientos, las imperiosas necesidades de toda ciudad moderna.

Antes que drásticas intervenciones de cirugía urbana, en la España de la segunda mitad del siglo XIX se generalizaron las operaciones de corrección por medio de alineaciones y ensanches de calles. La limitada incidencia de estas reformas interiores sobre el paisaje urbano contrasta, en cambio, con la tendencia a arrasar las viejas murallas, entre las que se incluyeron desde los restos medievales a los recintos abaluartados de época Moderna ${ }^{25}$. Razones prácticas, como los perjuicios para la higiene o la expansión de las poblaciones, pero también simbólicas, al ser vistas como la estampa de sistemas políticos superados, confluyeron para activar la transformación de aquella imagen de ciudades encor- 


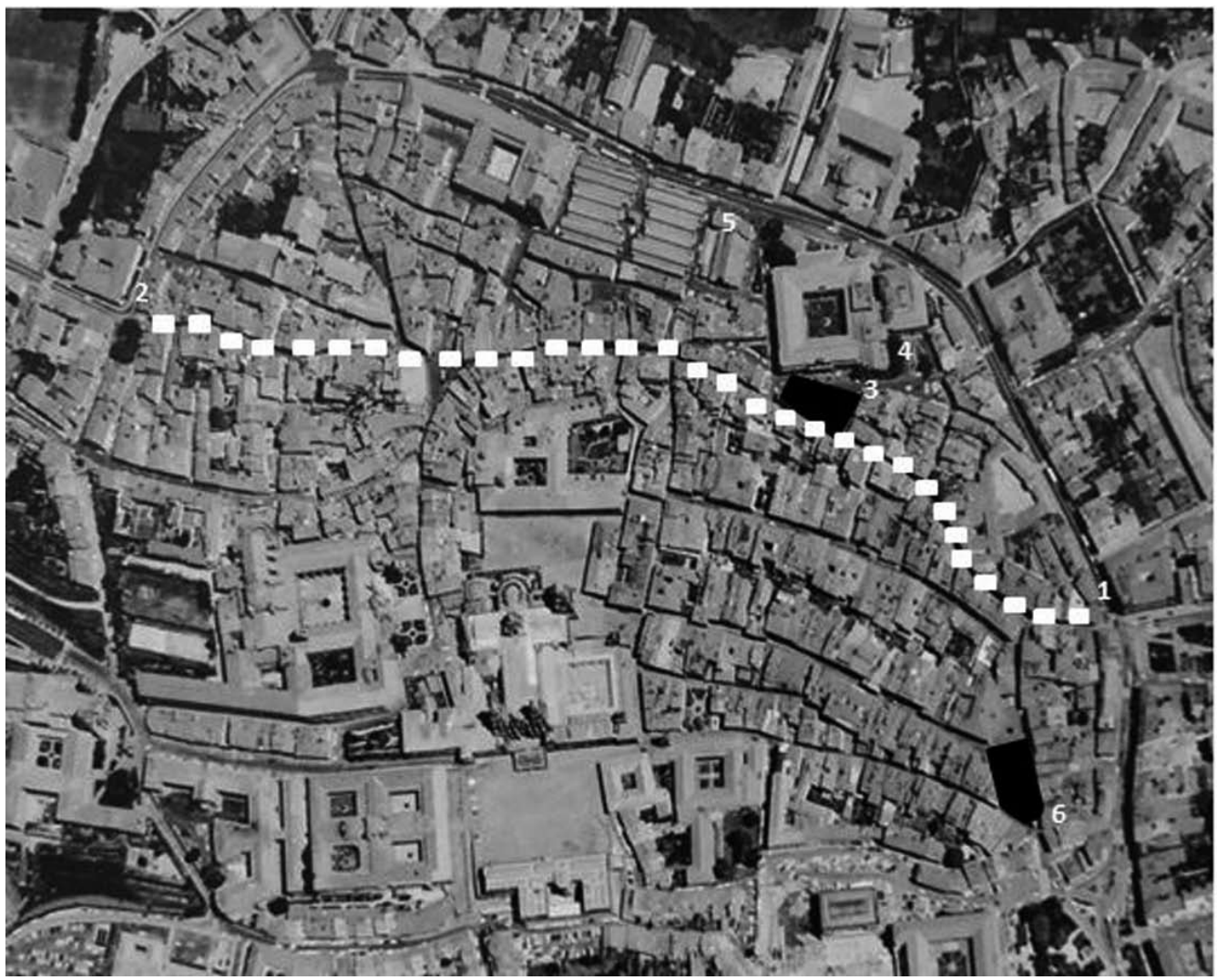

Fig. 2. Casco histórico de Santiago con el trazado de la "Gran Vía" propuesta en 1888

Leyenda:

1. Porta da Mámoa

2. Porta de san Roque

3. Manzana de casas en el lateral impar de la calle Calderería

4. Edificio de la Universidad

5. Mercado de Abastos

6. Manzana sudoeste de la plaza del Toral

setadas y cerradas por murallas, especialmente marcada en las consideradas plazas fuertes. En las ciudades gallegas estos derribos decimonónicos se concentraron en episodios claves de cambio político, comenzando por las dinámicas revolucionarias de 1840 y 1854 , como lo prueba que A Coruña y Pontevedra iniciaran sus derribos en la primera fecha, mientras que en Vigo el primer intento se produjo en la segunda, tras la constitución de una junta de gobierno local26. El completamiento del proceso tuvo lugar en la capital coruñesa desde 1868, con la autorización para demoler las murallas de la Pescadería ${ }^{27}$, siendo un año más tarde cuando se abordaron en Vigo los derribos que, ampliando los iniciados en 1861, permitieron la definitiva expansión de la ciudad desde la zona de la Puerta del Sol y Príncipe $^{28}$.

Por supuesto es necesario anotar la importante excepción que en Galicia representó la conservación de la muralla romana de Lugo, objeto ya desde finales del siglo XVIII de afirmaciones sobre su valor como antigüedad ${ }^{29}$. La definitiva protección monumental, iniciada con la tramitación de una propuesta de ley en 1912, se demoró hasta el año 1921 (RO 16/04/1921), en un contexto de declaraciones que afectaron 
a otras murallas romanas y medievales en España como las de Ávila (1914), Toledo (1921), Granada (1922) o Cáceres (1930). En cuanto a Santiago de Compostela, la muralla medieval no llegó a verse afectada por estas coyunturas decimonónicas ya que desde el siglo XVI había comenzado su ruina y gradual eliminación, intensificada durante el XVIII por los aforamientos y apropiaciones de diferentes porciones a cargo de los vecinos al levantar sus casas arrimadas ${ }^{30}$ Esta desaparición pudiera relacionarse con la apreciación del urbanismo medieval de la propia ciudad, como se detecta en las palabras del escritor romántico Neira de Mosquera al lamentar la pérdida de la muralla y sus puertas medievales como "últimos restos de la arquitectura antigua" ${ }^{31}$, en una visión nostálgica que pronto se acrecentaría ante la decadencia de la población por los reveses que representaron la desamortización y no ser designada como capital provincial $^{32}$.

Dado que los derribos de murallas se iban acometiendo con gran lentitud, similar a la que también estaba requiriendo la planificación y construcción de los ensanches ${ }^{33}$, no debe extrañar que buena parte de la legislación española se orientara hacia las operaciones de reforma interior. Al mantenerse los problemas de insalubridad y anarquía de los trazados históricos, en 1879 se aprobó la Ley de Expropiación Forzosa que, tras décadas de conflictos, venía a establecer la prioridad de los intereses públicos sobre la "sagrada propiedad particular"; y en 1895 la Ley de Saneamiento y Mejora Interior de las Grandes Poblaciones, que se ha interpretado como desarrollo de la anterior ${ }^{34}$. En conexión con estas bases legislativas, y en unos años finales de la centuria en los que el crecimiento de las ciudades experimentaba una significativa aceleración, por toda España se impulsaron proyectos de aperturas de las entonces llamadas grandes vías, casi siempre buscando facilitar los accesos y descongestionar parcialmente los centros históricos ${ }^{35}$.

Este fue precisamente el contexto para la propuesta lanzada en Santiago de Compostela en el año 1888 sobre la apertura de una gran vía que atravesara todo su casco histórico de sur a norte (Fig. 2), expuesta en la prensa local en un artículo publicado en la primera página de la Gaceta de Galicia del 25 de junio de $1888^{36}$. Etiquetable entre las operaciones que Benevolo bautizó como de haussmanización ${ }^{37}$, su autor no olvidaba ninguna de las justificaciones habituales, desde la higiene al embellecimiento pasando por los beneficios para obreros y promotores, y por supuesto la carga retórica en cuanto a exagerar la oportunidad de "mejorar el triste y anticuado aspecto de la población"38. De hecho, la ambiciosa propuesta entroncaba con una decisión municipal acordada el año anterior para proceder al ensanche y ampliación de la calle Calderería: un proyecto en el que ya se contemplaban expropiaciones y derribos de casas para solucionar la estrechez de esta vía desde su arranque, en la confluencia con Cinco Calles, y que además podía beneficiar al cercano edificio de la Universidad, necesitado de una ampliación y mejores accesos $^{39}$.

En realidad, el origen para estas drásticas propuestas remitía a la idea de ampliar el céntrico edificio de la Universidad, según la decisión que había tomado en 1886 el rector Antonio Casares y que había encontrado el decisivo apoyo de Eugenio Montero Ríos desde su cargo como ministro de Fomento. El proyecto, encargado en 1887 al arquitecto Ricardo Velázquez Bosco, tardó dos años en elaborarse y resolver una reforma interior en la que al edificio neoclásico se le añadiría un tercer piso, lo que sirvió de excusa para una intensa polémica en la que se mezclaron argumentos políticos con los más estrictamente estéticos por la grave alteración de la fachada principal, al suprimir su frontón original40. Cuando este proyecto estaba todavía iniciando su andadura, afloró el pensamiento de que el renovado edificio de la Universidad debería disponer de un acceso más cómodo y privilegiado, algo sólo posible eliminando la manzana frente a su fachada, con las casas correspondientes a la acera de los impares del tramo Callobre-Calderería a Cinco Calles, y por supuesto ampliando en todo su recorrido no sólo la propia calle Calderería sino también la de Huérfanas con la que enlazaba. Así planteada, la propuesta de "gran vía" iba a servir, además, para mejorar los desplazamientos de personas y mercancías hacia el mercado de abastos, puesto que el nuevo eje arrancaría de una de las entradas principales al casco histórico, la puerta de la Mámoa ${ }^{41}$, discu- 
rriendo por las calles de Huérfanas y Calderería hasta rebasar la Universidad y llegar a la altura de un mercado lastrado desde su apertura en 1873 por una deficiente conexión con la zona más apretada del tejido urbano ${ }^{42}$.

Para el desarrollo completo de la futura "gran vía" compostelana, el corte en el tejido histórico se extendería desde la puerta de la Mámoa a la puerta de san Roque, exigiendo la expropiación y demolición de todas las casas ubicadas a ambos lados del nuevo eje hasta alcanzar un ancho máximo de $18 \mathrm{~m}$., que incluso permitiría la circulación de un tranvía. Con un coste estimado en doce millones de reales, tras indemnizar el centenar de viviendas afectadas las obras se realizarían en dos secciones sucesivas, desde Huérfanas a Cinco Calles y desde Cinco Calles a San Roque, en un plazo temporal de 8 años. Al margen de los razonamientos de viabilidad económica, ya que se contaba con recuperar el gasto de las expropiaciones y obras gracias al valor de los nuevos edificios y los correspondientes impuestos a establecer, el resultado final sería, en opinión del autor de la propuesta, "una verdadera calle, según las reglas modernas de embellecimiento e higiene", susceptible de dar trabajo a los obreros y mejorar el conjunto de la población, y por supuesto el edificio de la Universidad, que con este nuevo acceso sería el más claramente beneficiado.

Aunque la quimérica propuesta nunca llegó a traducirse en un verdadero proyecto urbanísti$\mathrm{CO}^{43}$, sus argumentos de fondo, sobre todo en lo concerniente a la falta de higiene e irregularidad en el trazado intramuros de la ciudad, recogían un sentir entre las autoridades locales sobre las mejoras que precisaba Santiago de Compostela, arraigado ya desde la redacción de las primeras Ordenanzas de policía urbana en la lejana fecha de $1780^{44}$. Con el paso del tiempo, a aquellas actuaciones guiadas por los principios de salubridad y ornato característicos de la llustración se añadió el atractivo que representaría disfrutar de grandes avenidas o bulevares, anhelándose seguir el ejemplo de las grandes capitales donde se habían abierto vías de este tipo. Así lo refrenda una propuesta municipal, ahora para ampliar la plaza del Toral y dotarla de un amplio acceso por la puerta Faxeira, impulsada en noviembre del año 1900. Aprovechando las más recientes reformas legales, como la Ley para Saneamiento de Poblaciones de 1895 antes citada, el objetivo era derribar por completo la manzana de casas entre las calles Bautizados y rúa do Vilar (Fig. 2), comprendiendo desde el $n^{\circ} 69$ de esta última vía a todos los pares de Bautizados, en una actuación que se estimaba lógica para conectar adecuadamente el casco viejo con la Alameda y, a la vez, con el ensanche de la población proyectado por las mismas fechas en los terrenos conocidos como Agros de Carreira ${ }^{45}$.

El aspecto que presentaba aquella entrada a la ciudad por la muy transitada puerta Faxeira justificaba a ojos de los responsables municipales este proyecto de derribos para abrir un corto tramo de avenida con punto focal en la plaza del Toral. La conveniencia de este limitado percement se reavivó en mayo de 1914, durante las primeras gestiones para levantar en Santiago de Compostela un monumento a Eugenio Montero Ríos, al vincular esta avenida de entrada hacia la plaza del Toral con una de las posibles ubicaciones para la estatua con la que se quería homenajear al político ${ }^{46}$. Cinco años más tarde, el insatisfactorio y polémico emplazamiento de este monumento a Montero Ríos en el centro de la plaza del Obradoiro se volvió a conectar con la idea de expropiar y derribar en su totalidad la pequeña manzana de casas que taponaba la apertura de la plaza del Toral hacia la Alameda. Una moción presentada por el concejal Manuel Villar Iglesias, médico con destacado protagonismo en la vida cultural compostelana, proponía ahora urbanizar el solar resultante como un pequeño jardín, una zona verde en la entrada del denso casco histórico que sirviera de transición visual hacia la Alameda, y a la vez, como secundó otro concejal, crear un marco más agradable para la reubicación del controvertido monumento ${ }^{47}$.

La recurrencia de las propuestas para abrir amplias avenidas y conectar el casco histórico compostelano con el ensanche como soluciones de descongestión y modernidad se rastrea todavía hasta el año 1930. En esta última fecha, un nuevo artículo de prensa en el que se sugerían distintas mejoras para la población seguía citando la apertura de una "gran vía" como una posibilidad, aunque ahora contraponiendo el 
mayor interés en la conservación de la estructura y estética urbana tradicionales, sedimentadas con el paso de los siglos y que por ello debían prevalecer a toda costa:

Aun cuando fuera posible hacer en este pueblo una gran vía opondríase al proyecto la estructura tradicional de Santiago, donde todas las obras públicas deben avanzar en armonía con sus típicos estilos dejando siempre, como fase predominante y orientadora, la nota ancestral que se destaca con añejo color en sus templos, rúas y edificios civiles $^{48}$.

Es interesante comprobar que en el mismo año 1930 viera la luz una denuncia sobre las amenazas al ambiente de un conjunto, en este caso de arquitectura tradicional, exponiendo lo que estaba ocurriendo en el pueblo pontevedrés de Combarro (Fig. 3). Tras reconocer que en Galicia todavía existían villas y pueblos enteros en los que disfrutar de abundantes muestras de las construcciones tradicionales, el escritor y profesor de dibujo Modesto Prieto Camiña, miembro de la Sociedad de Amigos del Arte, responsabili- zaba a las autoridades municipales de poco celo a la hora de vigilar los excesos de la especulación inmobiliaria, poniendo el ejemplo de lo que se había encontrado en Combarro, pese a estar ya por entonces publicitado como "pueblo típico":

La hilera de viviendas sostenidas por columnas, que forma una de las principales rúas de Combarro, ha sido rota por el Progreso. Donde hasta hace muy poco se erguía una esas casas, hoy se ve una edificación de arquitectura modernisima, muy estilo rascacielos norteamericano -claro que sin tales pretensiones respecto a la altura- a punto de ser terminada, y que es como una afrenta a la rancia nobleza del conjunto y un aviso al departamento oficial encargado de velar por la salvaguardia de tales bellezas, que aun cuando no están bajo su tutela merecen respeto ${ }^{49}$.

A la vista de estas firmes tomas de posición conservacionistas, en las que una ciudad o un conjunto eran ya considerados como portadores de valores de arte e historia, los que ayudaban a definir su carácter "típico", la pregunta obvia es qué había ocurrido anteriormente para que lle-

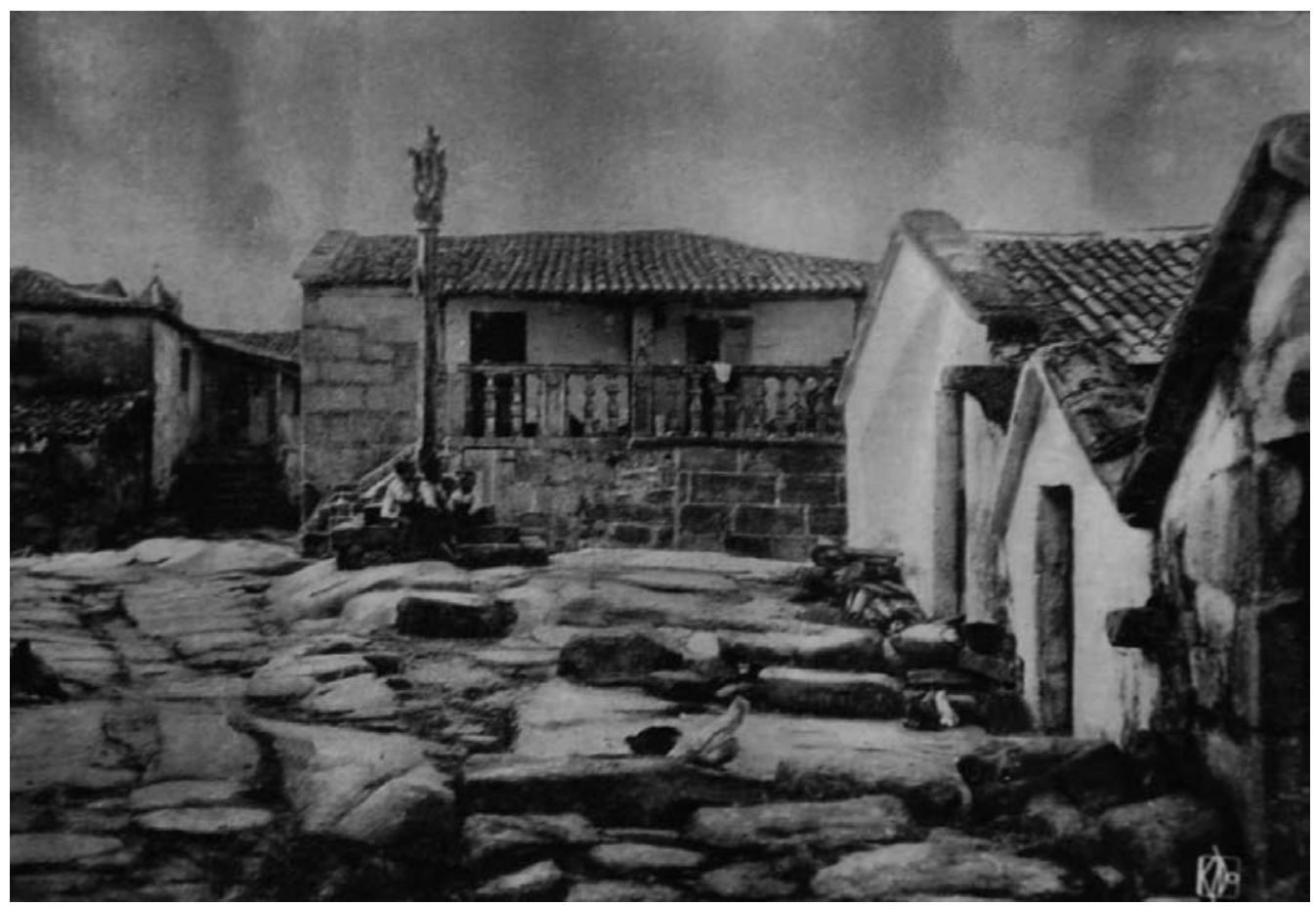

Fig. 3. Combarro en 1936 (Ksado) 
gara a surgir esta nueva valoración y ampliación de enfoque frente a la restrictiva mirada decimonónica.

\section{El impacto de una primera modernidad: reacciones ante las arquitecturas del eclecti- cismo al modernismo}

La nueva aproximación al paisaje urbano y sus valores fraguada durante el primer tercio del siglo XX coincidió con la llegada a España de las ideas de Camillo Sitte -Der Städtebau nach seinen künstlerischen Grundsätzen (1889)- y Charles Buls -L'esthétique des villes (1893)-, dos de los pioneros en considerar la ciudad como obra de $\operatorname{arte}^{50}$. Estas influencias se superpusieron en los primeros años del siglo con la no menos decisiva aportación de Gustavo Giovannoni, quien combinó la ampliación de la protección del monumento hacia su entorno con la defensa del concepto de "arquitectura menor" 51 . Las reflexiones expuestas en el ámbito de la Academia de Bellas Artes de San Fernando muestran algunos avances hacia este mismo cambio de perspectiva, ya que, como en su momento analizó Ángel Isac, fue entre los últimos años del siglo XIX a los primeros del XX cuando afloraron discursos y alusiones sobre el interés de la tipología residencial o el urbanismo desde el punto de vista cultural ${ }^{52}$. En paralelo, también comenzaron a atisbarse unos primeros ensayos para extender la categoría de monumento y, en línea con las ideas de Giovannoni, iniciar la salvaguardia de construcciones más modestas, siempre que pudieran aportar valores como testimonios históricos 0 artísticos ${ }^{53}$.

Ahora bien, para un ámbito periférico como Galicia, ajeno a los principales debates y posicionamientos teóricos, entre los factores que sirvieron para activar la nueva mirada hacia las viejas ciudades tuvieron mayor protagonismo algunas reacciones aisladas contra los rumbos que estaba tomando la edificación doméstica y comercial desde los años finales del siglo XIX. Variaciones en los códigos formales y pautas de inserción en la ciudad, sobre todo por el contraste en escala, soluciones compositivas y materiales frente a las edificaciones tradicionales, actuaron como catalizadores para sacudir de su sueño a poblaciones aletargadas que, como Santiago de Compos- tela, comenzaron a descubrir unos valores que se estaban poniendo en peligro. Se trataba, en el fondo, de un choque estético que se fue intensificando con la maduración de las distintas opciones eclécticas hasta alcanzar su clímax durante el auge del modernismo, cuando ya entraron en juego dos polémicas cuestiones: los materiales industriales, en especial el cemento, al que se seguía mirando con el menosprecio heredado del XIX, y la novedad de los ornamentos Art Nouveau, considerados como caprichosos y ajenos al buen gusto. De nuevo fue Santiago de Compostela el origen y amplificador de las voces más críticas debido a la conjunción de su densidad monumental en la parte histórica con la anomalía de un ensanche paralizado, que no permitía el normal desarrollo de la ciudad moderna, reflejo último de una situación de declive y estancamiento ${ }^{54}$ que tuvo su confrontación y reacción más aguda con ocasión del muestrario de las cosmopolitas tendencias de la arquitectura fin de siècle reunidas para la celebración de la Exposición Regional Gallega de $1909^{55}$.

El efecto provocado por la aparición de los primeros edificios eclécticos y modernistas, un fenómeno que Bonet Correa englobó dentro de las polémicas por la "política de substitución" 56 , sólo admite comparación con lo ocurrido en el último tercio del siglo XVIII, cuando las nuevas pautas estéticas clasicistas, apadrinadas desde la Academia de San Fernando, entraron en colisión frontal con el barroco local ${ }^{57}$. En cambio, durante los dos primeros tercios del XIX habían sido precisamente arquitectos de formación académica los encargados de aclimatar al paisaje urbano de Compostela el vocabulario y sistema compositivo clasicistas, con una armónica inserción de edificios tan céntricos como el Teatro Principal (Manuel de Prado y Vallo y Faustino Domínguez Domínguez, 1841), el Café Suizo (Prado y Vallo, 1858), o el palacete de Ramón María de la Maza (Leopoldo López, 1862) ${ }^{58}$. La situación comenzó a variar durante la década de los años setenta del siglo XIX, coincidiendo con la implantación de los nuevos modelos de vivienda burguesa traídos a la ciudad de la mano de profesionales ya formados en la Escuela Especial de Arquitectura como Agustín Gómez Santamaría, Daniel García Vaamonde, Antonio Bermejo Arteaga o Faustino Domínguez Coumes-Gay. El nuevo estatus de la 
vivienda como mercancía, al concebir la casa no sólo como un refugio sino también como una inversión y, por ello, un marco elocuente para la ostentación del nivel socioeconómico de la familia propietaria ${ }^{59}$, acarreó importantes cambios estéticos, con un nuevo sentido de la elegancia y el decoro urbano, perceptibles en el desarrollo de balcones, miradores y galerías. Además, junto a la mayor altura de pisos y la amplitud en los huecos de fachada, sobre todo en planta baja al potenciar el portal principal pero también la superficie destinada a escaparates de las tiendas, se desarrolló un vocabulario ornamental con elementos de base clasicista o barroca, ahora combinados con creciente libertad y exhibicionismo.

El nuevo énfasis decorativista fue nota distintiva de la intensa actividad de los maestros de obras: clase profesional que en España compensaba su carencia de formación académica con un acercamiento más desprejuiciado a los modelos que circulaban en álbumes y repertorios, conjugando la economía y el recurso a soluciones locales con una estética que pudiera resultar más atractiva para promotores y clientes $^{60}$. En Santiago no debieron pasar desapercibidas las realizaciones de maestros de obras como Manuel Otero y López, responsable del diseño de la vivienda para Silvestre García en la Senra, n²7-29 (1878) y del Hotel Suizo en Cardenal Payá, propiedad de Antonio Mengotti (1879); o especialmente Manuel Pereiro Caeiro ${ }^{61}$, con una trayectoria profesional abundantísima en encargos privados, entre los que sobresale por su ruptura de escala la vivienda y sede para la banca Hijos de Olimpio Pérez (Fig. 4), en la plaza de Cervantes $(1887)^{62}$. En relación con este mismo inmueble, al impacto provocado por las primeras sedes bancarias se sumaron los grandes almacenes, otra de las tipologías decisivas para la renovación urbana del fin de siglo ${ }^{63}$. Así, la entrada de estas nuevas tipologías de uso comercial dejó una acusada huella en la vieja Compostela, ya que en no pocas ocasiones estos voluminosos edificios provocaron la destrucción de viejas casas y la unificación de sus solares ${ }^{64}$. Incluso una ciudad con unas dinámicas capitalistas más intensas, como A Coruña, todavía a comienzos del siglo XX vio como la nueva sede del Banco Pastor tenía que vencer la inicial resistencia municipal para alcanzar los $35 \mathrm{~m}$. de altura que

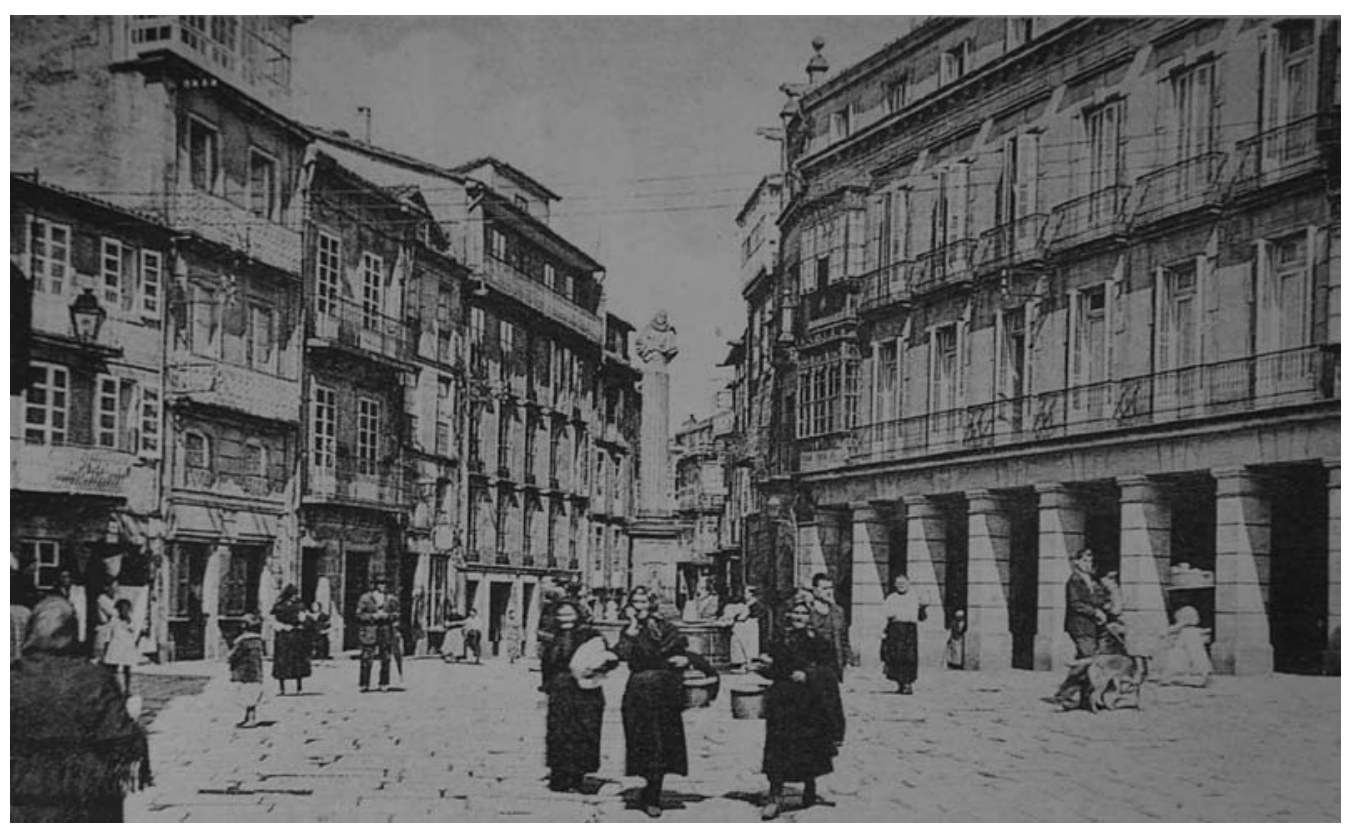

Fig. 4. Plaza de Cervantes con la sede de la Banca Hijos de Olimpio Pérez (Cabo Villaverde y Costa Buján, Imaxe de Compostela, 1991) 
finalmente dominaron durante décadas sobre el provinciano perfil de la ciudad ${ }^{65}$.

Con todo, la sacudida más intensa se produjo a partir del año 1905, cuando en Compostela hicieron su aparición las primeras edificaciones modernistas, agrandando la quiebra ya muy evidente con la arquitectura tradicional por sus novedades técnicas y decidido espíritu antiacadémico. Las versátiles posibilidades compositivas y decorativas de las fachadas realizadas en cemento, al jugar con las asimetrías o moldear cualquier motivo ornamental, incorporando además una acusada proyección de las decoraciones en relieve sobre el plano de la fachada, tuvieron en Compostela dos tempranas muestras en las destacadas viviendas diseñadas por Jesús López de Rego para los números 6-8 del Preguntoiro (1905) y 2-4 de Cardenal Payá (1914), ambas con un protagonismo urbano comparable al antes citado banco de Olimpio Pérez (Fig. 5). Si el primero enfatizaba la significación del portal principal de acceso a través de los novedosos estilemas modernistas, el segundo, también co- nocido como casa Gamallo, insistía en la composición de pilares y amplios huecos adintelados para una dedicación comercial que además aprovechaba inteligentemente el curvo desarrollo de la fachada.

Más allá de los cambios compositivos y de escala, fueron los detalles ornamentales realizados en cemento, desde las hojas y flora hasta las máscaras femeninas que se situaban bajo los balcones o en los pináculos de remate, los que suscitaron la mayor reacción, con comentarios que enfrentaban sus novedades y atrevimientos a la pétrea contundencia geométrica de la barroca Compostela. En este sentido, fue una minoría de intelectuales la encargada de canalizar las primeras críticas a unas tendencias estéticas ya enjuiciadas como un ataque a la ciudad tradicional ${ }^{66}$. Con motivo de la celebración de la Exposición Regional Gallega del año 1909, la siempre perspicaz Emilia Pardo Bazán no dejó pasar la ocasión para pulsar el estado de opinión local y alzar su voz frente a las novedades en una ciudad que conocía muy bien, por haber fijado

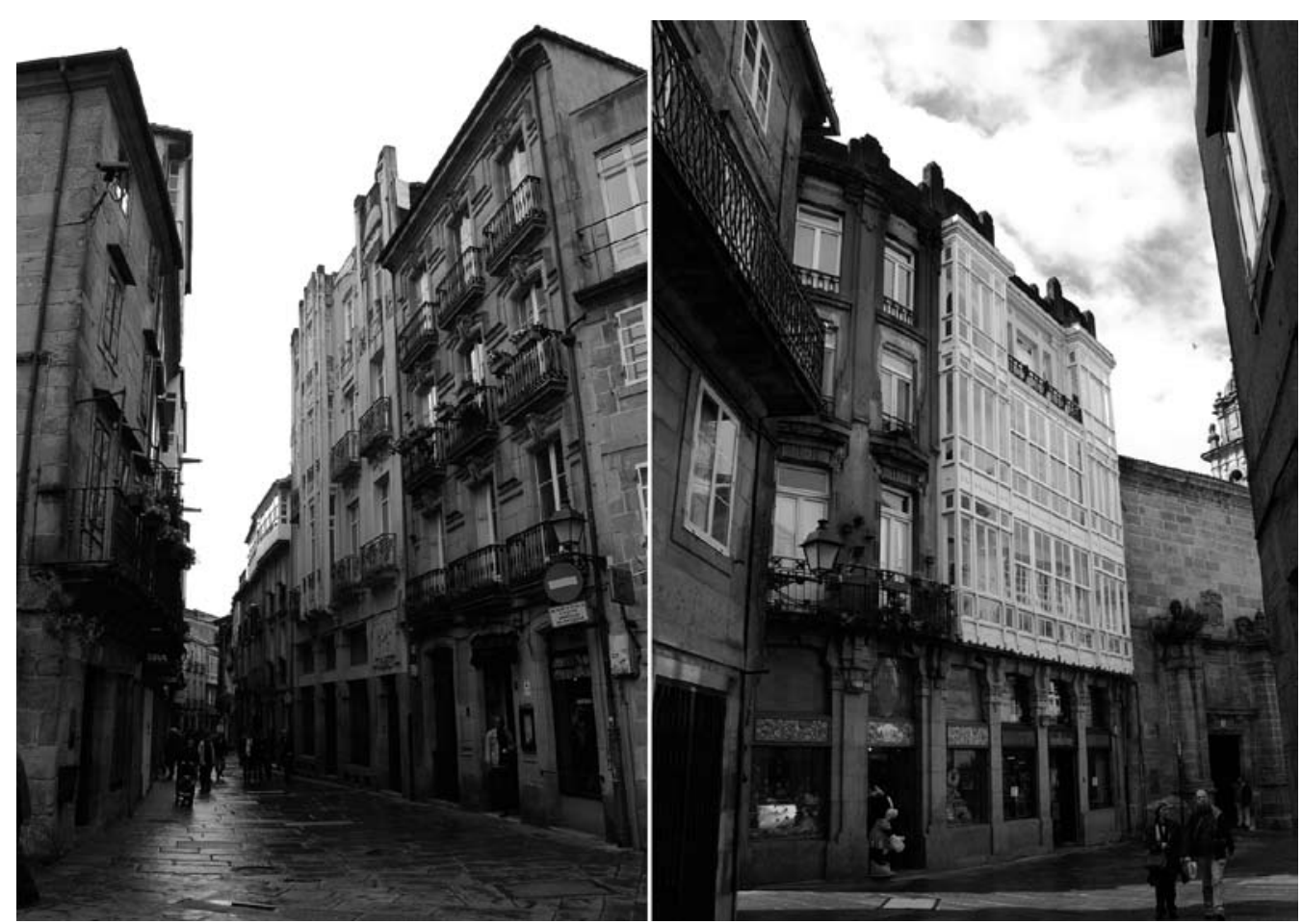

Fig. 5. Edificios modernistas en calle Preguntoiro, 6-8 y Cardenal Payá, 2-4 (Autor) 
aquí su residencia durante el curso 1868-1869, cuando su marido iniciaba sus estudios de Derecho en la Universidad ${ }^{67}$. Emilia apuntó certeramente a las nuevas construcciones y soportales "de estilo comercial", incluyendo por tanto a los primeros bancos, almacenes y comercios construidos desde finales del XIX, como los principales responsables de una ruptura que también se había apoyado en las constantes intervenciones municipales para la alineación y ampliación de las viejas calles:

Es en Santiago de Compostela, pueblo joya, pueblo relicario, en que persiste la imagen del pasado con la misma viveza que si fuese presente; pueblo donde las piedras tienen voz, y donde los edificios nuevos horripilan como una profanación y una incongruencia. Los forasteros y extranjeros inteligentes que atrajeron las fiestas del Año Santo, se lamentaban de ver casas de nuevo cuño, calles que intentan ponerse en fila como soldados bien instruidos, y soportales altos, de estilo comercial, porque la fealdad prosaica de la vida actual se les aparecía de realce al contrastar con la belleza de lo que fue, con su señorío reposado y aristocrático. Yo me acordaba de aquella botella de tinta arrojada en Salamanca a un edificio color de rosa y con decorado modernista, y sentía impulsos de adquirir varios barriles de ese líquido insidioso que las máquinas y los lápices de anilina van haciendo innecesario, pero que aún puede servir para ejecutar un acto de justicia. Me hubiese encantado embadurnar todo lo que en Santiago se ha construido desde hace treinta años, a ver si así caen los ediles en la cuenta de que no hay derecho ${ }^{68}$.

La alusión a un polémico edificio Art Nouveau de Salamanca confirma la radical oposición frente a lo que la condesa de Pardo Bazán describirá en otros textos como "parodia modernista", en sintonía con el descrédito que la primera versión llegada a España de este estilo mereció para los intelectuales de comienzos del siglo $X X^{69}$. Para la escritora, que en su momento también había sido pionera en criticar los excesos del modernismo literario, lo más deplorable de estas nuevas construcciones radicaba en sus materiales y libertades ornamentales, rayando el mal gusto. Como reiterará en escritos posteriores, no ocultaba su comprensión hacia los ataques dirigidos a una casa "modern style" salmantina, manchada con botellas de tinta por romper con la "dorada majestad regia" de la ciudad. Aun- que en su momento la conocida como Casa Lis (1905), promovida por el industrial Miguel de Lis con proyecto del arquitecto jerezano Joaquín de Vargas y Aguirre $^{70}$, había desencadenado ya unos primeros comentarios críticos, no era esta la construcción a la que apuntaba Emilia, sino a la que alojó la tienda La Favorita, en la calle Zamora de la misma localidad ${ }^{71}$; esta casa, derribada en los años cincuenta, ocupaba el número 5 de la calle, y su propietario, Lorenzo Fernández Santiago, había solicitado un permiso "para revocar la fachada" que dio como resultado la incorporación de unas escandalosas decoraciones en cemento, hasta el punto que en julio de 1905 el dueño solicitó nueva autorización para pintar la fachada y, de paso, quitar las "figuras" que en ella existían ${ }^{72}$. Según precisa Emilia en otros artículos, sobre el fondo rosa salmón de esta casa se dispusieron sendas cariátides modernistas que destacaban por exhibir "lo que en la antigua literatura francesa se llamaban appas, y demostraban su aptitud para amas de cría", por lo que la escritora encontraba justificado que un hombre sensato, no sabe si por tributo a la moral o por respeto a la belleza, les arrojara una botella de tinta ${ }^{73}$. De ahí también que en Santiago el mismo respeto a la belleza de lo típico, al encanto de una añeja ciudad, despertara su deseo de atacar por escrito, e incluso vandalizar físicamente, las novedades formales más superficiales de los que acertadamente calificaba como "decorados modernistas".

La conservadora posición de Emilia se refleja en el mismo artículo en su crítica a la obsesión por las calles rectas y las edificaciones dejadas caer en el abandono, esto último en directa alusión al proyectado derribo de la barroca Casa de la Inquisición, sobre cuyo solar ya se especulaba como emplazamiento idóneo para un moderno hotel, futuro Hotel Compostela (1930). En los momentos en los que estaba escribiendo, y teniendo a la vista el eclecticismo más cosmopolita y festivo dominante en las arquitecturas levantadas para la Exposición Regional de 1909, la escritora coruñesa sólo podía temer que el proyecto de un gran hotel se concretara según las mismas tendencias; y no era eso, desde luego, lo que deseaba para un solar emplazado a las puertas de la vieja Compostela. Su pensamiento reclamaba, por el contrario, una conservación del ambiente 
urbano tradicional, en el que las nuevas edificaciones respetaran los estilos y modos constructivos locales, recuperando la belleza perdida por los primeros impactos de la modernidad ${ }^{74}$.

Amiga del arquitecto y restaurador Vicente Lampérez, es posible también que Emilia Pardo Bazán, gracias a sus frecuentes viajes a BarceIona, pero sobre todo a sus amistades literarias en la ciudad condal, estuviera al tanto del reconocimiento del barrio gótico como conjunto o síntesis de la vieja Barcelona, iniciado en los años que transcurrieron desde 1908 a 1911, en conexión con los derribos para las obras de la vía Laietana ${ }^{75}$. No obstante, la escritora manejaba también otras referencias internacionales de mayor calado, como dejan traslucir sus comentarios sobre la ciudad de Nuremberg, publicados durante el año 1889 en que había viajado por diferentes localidades alemanas, alabando su apariencia detenida en el tiempo, libre de la obsesión por las alineaciones pero a la vez plena de vida moderna ${ }^{76}$. Nuremberg como modelo para la conservación de un ambiente urbano, de acuerdo con las ideas de Sitte, reaparecerá en un texto sobre la ciudad de Betanzos publicado originalmente en El Imparcial en julio de 1893, en el que, con la pretensión de describir un día típico de feria, Emilia aportaba unas coloristas líneas sobre los detalles más pintorescos de su caserío (Fig. 6), contrapuesto a la vulgaridad de la arquitectura doméstica finisecular:

Al pie de la colina donde se agrupaba con pintoresco artificio el caserío de Betanzos, tendíanse los esteros a manera de tapiz cosido a retazos de raso azul celeste, el azul del agua, y felpa verde pálido, finísima de color, el tono de los juncales. Y cuando digo el caserío de Betanzos, no se imagine nadie un conjunto apelmazado de esas insípidas grilleras modernas, tan aburridas, tan previstas, de tan necia regularidad, que dan ganas de morirse porque recuerdan el encasillado de las necrópolis. El caserío de Betanzos - a pesar de la plaga reinante de las mejoras y ensanches y de la fatalidad de las reconstrucciones, que hacen estragos, sobre todo en las calles principales- conserva aún muchas más paredes, puertas y ventanas de los siglos XIII, XIV y XV que del actual. En Betanzos debiera

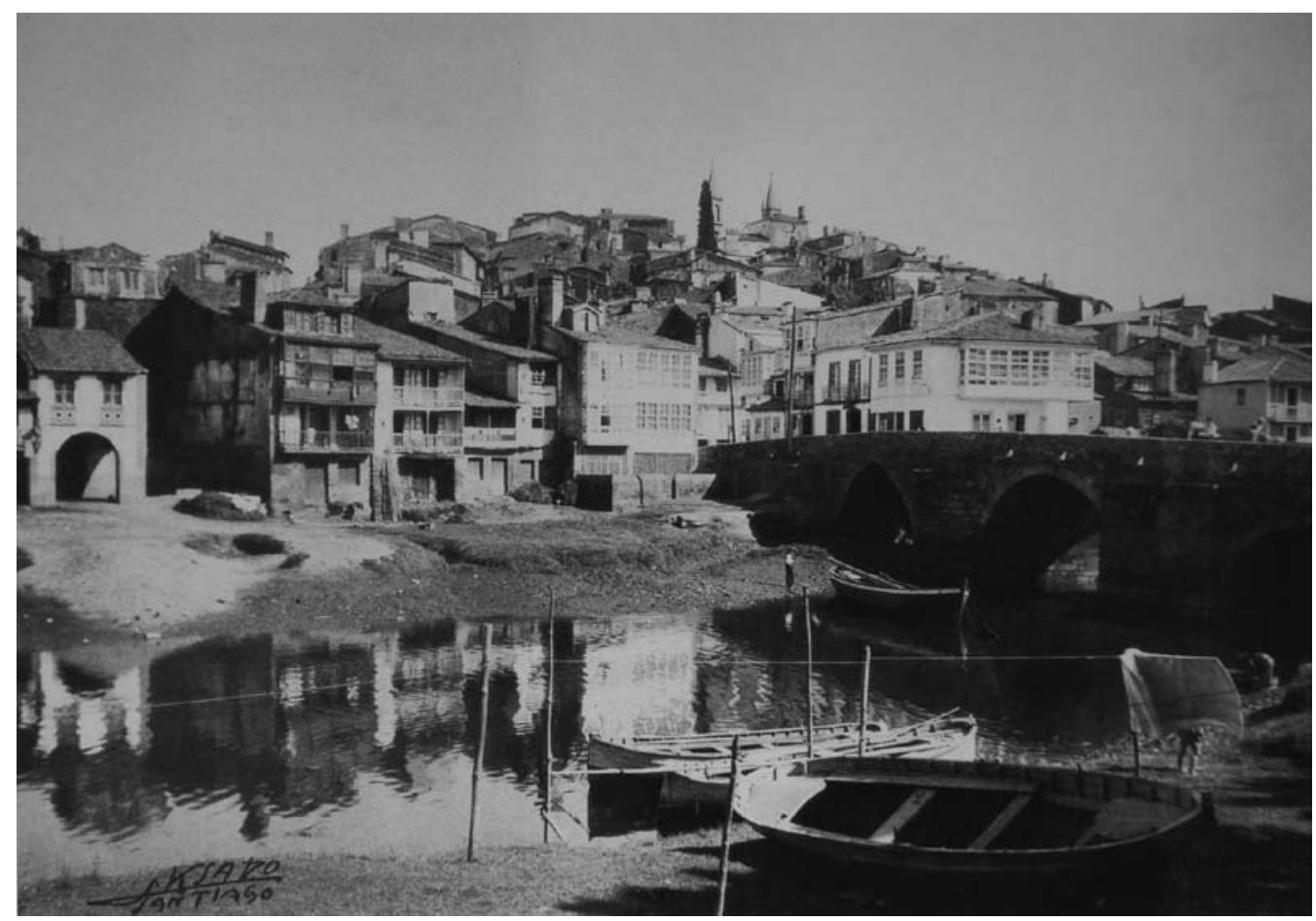

Fig. 6. Vista de Betanzos en 1925 (Ksado) 
practicarse lo que en Nuremberg: edificar lo nuevo al modo antiguo, respetando nimiamente la rica originalidad, la variedad fresquísima de las moradas viejas ${ }^{77}$.

Años más tarde, cuando todavía no había arrancado la ocupación del ensanche compostelano, la crítica a la traumática inserción de las edificaciones modernistas en el casco viejo se renovó gracias a la pluma del poeta Antonio Rey $\mathrm{Soto}^{78}$, al lamentar en un artículo publicado en 1922 la desaparición de unas "casas antiguas, de abigarrado pero insustituible aspecto, que eran altamente decorativas y pronunciaban el ambiente único de la ciudad", sustituidas por "el horrendo mazacote de un edificio modernista, sin espíritu y sin belleza"79. Aunque no es fácil identificar el emplazamiento exacto de ese edificio modernista, podría tratarse de alguno de los diseñados por López de Rego mencionados líneas atrás, o incluso el que conforma una pequeña manzana en Campo da Estrela $\mathrm{n}^{\circ} 28$ (J. Aguilar y J. López de Rego, 1908-1912), desde luego muy visible en la entrada al casco viejo por la puerta Faxeira. Esta crítica a las edificaciones discordantes se enlazaba en el texto de Rey Soto con la denuncia sobre la intención del Ayuntamiento compostelano de destruir un soportal en la rúa do Vilar ${ }^{80}$, lo que le movía a recordar la pérdida reciente de unos "venerables y pintoresquísimos soportales" que se conservaban al final de la rúa do Franco, en el lateral de los pares llegando precisamente a la puerta Faxeira ${ }^{81}$ (Fig. 7). Estas actuaciones le merecían una rotunda condena como atentado artístico:

Suprimirlos se me antoja un atentado a la hermosura de la ciudad, un borrón sobre su colorido incomparable y un desconocimiento supino de cómo debe ser exteriormente un pueblo con relación al clima de que disfruta. Los soportales son una cosa tan necesaria en Galicia, y sobre todo en Compostela, como los patios y las callejas retorcidas y estrechas en Sevilla y en Córdoba, los tejados puntiagudos en Suiza y los jardines con pequeños macizos de árboles y grandes praderas en Inglaterra ${ }^{82}$.

Las argumentaciones más elaboradas sobre los valores del ambiente urbano, que de hecho Rey Soto ya designa con este término, lo convierten en otro de los pioneros gallegos a la hora de reclamar la conservación de la ciudad histó- rica, o al menos de ciertos fragmentos urbanos, como podía ser el caso de viviendas que, si bien individualmente ofrecían escaso interés, por la agrupación de sus tramos de soportales contribuían al aspecto tradicional de Santiago ${ }^{83}$. Como contestación a sus denuncias, al día siguiente se publicaba en el mismo periódico un artículo en el que un miembro de la corporación municipal, aun otorgándole parcialmente la razón, justificaba la política aplicada desde hacía décadas al replicar que frente al resguardo y tipismo de los soportales (Fig. 8), su derribo obedecía a priorizar el interés de ganar luz y ventilación para la ciudad, sumando a las razones higiénicas otras acusaciones ya reiteradas largo tiempo atrás sobre la fealdad y deformidad que ocasionaban a las calles ${ }^{84}$.

Retornando a Emilia Pardo Bazán, sus primeros dardos dirigidos hacia las edificaciones modernistas se ampliaron en otro artículo aparecido

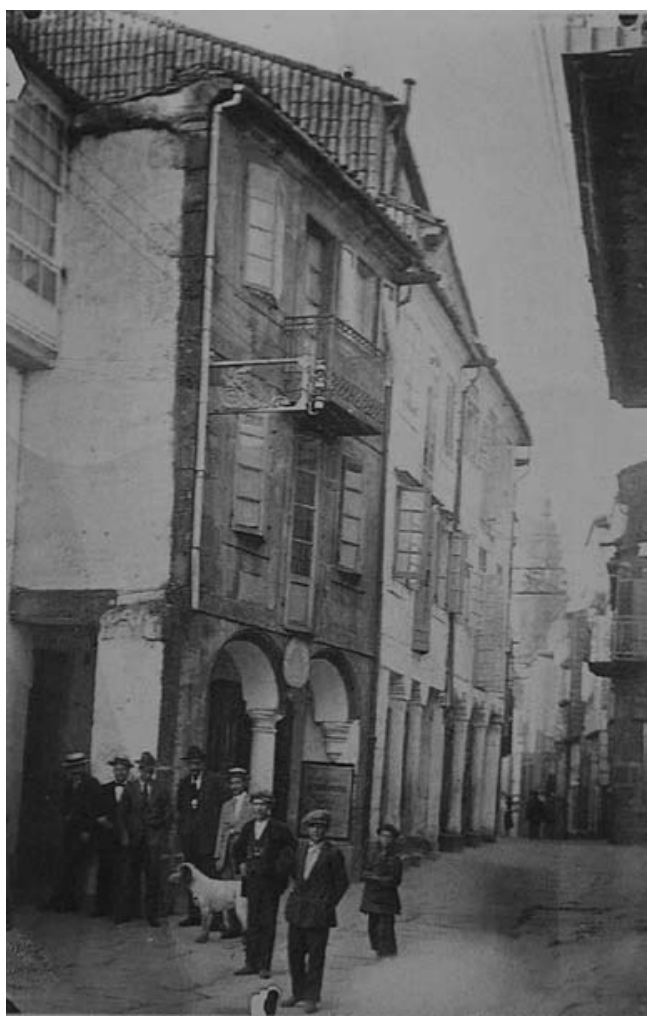

Fig. 7. Rúa do Franco con los soportales derribados en 1917 (Cabo Villaverde y Costa Buján, Imaxe de Compostela, 1991) 
en 1916 en La Ilustración Artística. Tras afirmar que la arquitectura moderna podía prescindir del arte, ya que por su funcionalidad no siempre ambicionaba una categoría artística, pero nunca podía ir contra el arte, en esta ocasión apuntaba directamente a los ornamentos modernistas realizados en cemento:

La mayor sencillez, modestia, hasta humildad en las edificaciones, admitido; pero afuera barandillas de cemento, balcones historiados de cemento, mascarones y ninfas y floripones de cemento, y demás atrocidades que infestan el nuevo caserío de lujo, de pretensiones modernas ${ }^{85}$.

La crítica al cemento Portland, acusado de ser un elemento dañino para la estética urbana ante su creciente difusión en las modernas viviendas construidas en España ${ }^{86}$, finalizaba con una descalificación absoluta de sus calidades estéticas al despreciar su "nota gris, fría, apagada", y su "odiosa lisura"87. Este discurso contra el cemento estaba preconizando una de las líneas argumentales que posteriormente asumieron los intelectuales comprometidos con la promoción del regionalismo arquitectónico, al

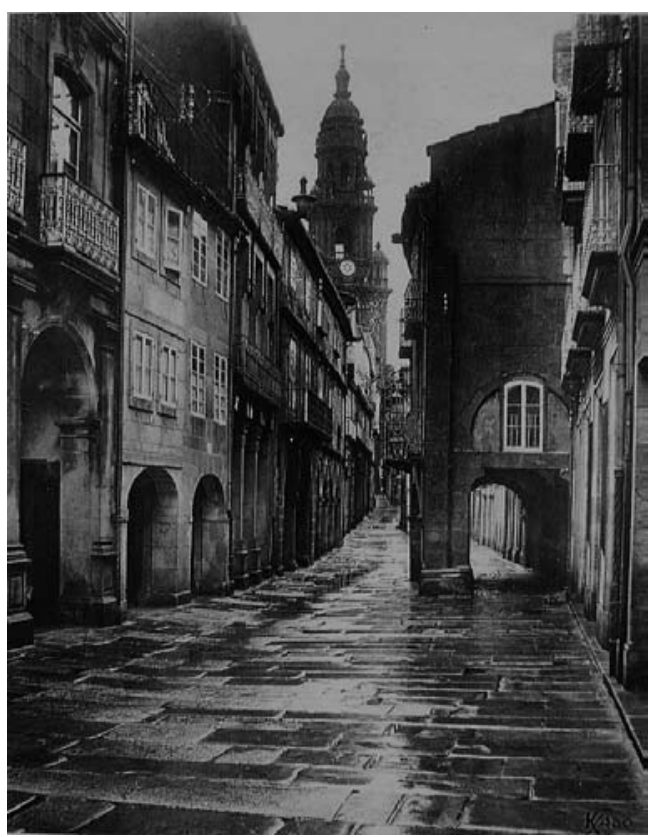

Fig. 8. Rúa do Vilar con sus típicos soportales a principios del siglo XX (Cabo Villaverde y Costa Buján, Imaxe de Compostela, 1991) ahondar en la confrontación entre los materiales modernos y los tradicionales o vernáculos ${ }^{88}$. El argumento cobró fuerza durante los años veinte, en un contexto de búsqueda de fundamentos sobre los que asentar la singularidad histórica y cultural de Galicia, que en el terreno artístico se orientó hacia la reivindicación de estilos tan esencialmente pétreos como el románico y barroco, valorados como las manifestaciones más relevantes en cuanto al desarrollo de una tradición de arquitectura que se pudiera sentir y presentar como propia. Para el ámbito de las ciudades que nos ocupa, esta mirada hacia lo vernáculo fue preparando otro punto de apoyo para el reconocimiento de la "arquitectura menor", la resultante de modos de hacer reiterados y perfeccionados durante siglos, en la que se podía detectar una íntima adaptación a un lugar y su historia ${ }^{89}$.

Las ideas esbozadas por la condesa de Pardo Bazán encontraron su punto de confluencia con el cauce del regionalismo con ocasión de la Exposición de Arte Gallego celebrada en A Coruña en el verano de 1917. Invitada a pronunciar una conferencia, Emilia abordó, entre otros puntos relativos a la evolución y caracterización artística de Galicia, el asunto de la conservación del ambiente típico en las ciudades gallegas. Dirigiéndose expresamente a la Asociación de Arquitectos de Galicia, constituida en Santiago en 1903, les exhortó a "escapar del mal gusto imperante" y buscar inspiración en las tradiciones propias, recordando que sobre todo era el caserío, como ya había denunciado con poco éxito en su pionero artículo sobre Betanzos, el principal responsable del carácter de las ciudades $^{90}$. Con respecto a esta defensa de los conjuntos tradicionales, priorizados ante los monumentos, la escritora coruñesa mostraba estar al día en cuanto a la valoración de la "arquitectura menor", citando además los argumentos positivistas de armonización con el clima, el paisaje o la historia que también compartirán Rey Soto o Castelao:

Se olvida además que las construcciones responden al espiritu y al cuerpo también de los países donde se alzan, y que por algo tenían patios con fuentes las casas de Sevilla, y soportales las de Santiago de Compostela y Pontevedra. Con dolor he visto desaparecer gran parte de estos sopor- 
tales del interesantísimo caserío de Betanzos, y con igual veré quizás, si vivo algunos años todavía, faltar los graciosos hórreos que bañan en el río sus pies, y quien sabe si recordarán las épocas lacustres... Y a los arquitectos que hayan de proyectar y dirigir edificios emplazados en la tierra gallega ¿con qué voces les gritaría yo que partiesen siempre de dos datos esencialísimos, ambos sugeridos por realidades? El pleno conocimiento, antes artístico que científico, de nuestra riqueza arquitectónica, unido al sentimiento profundo de su belleza, y el de las leyes que dictan la naturaleza y el clima especial de nuestra región. La armonía de los monumentos y las edificaciones con el paisaje y el ambiente, es una condición indispensable para evitar impresiones como las que a menudo se sufren, de disonancia horrible, ante determinadas construcciones urbanas y campestres ${ }^{91}$.

Conocedora de primera mano de las iniciativas internacionales para evitar la desaparición de las antiguas costumbres, "fisonomía" y "carácter" de los pueblos"92, Emilia Pardo Bazán estaba demandando a los arquitectos que se implicaran en algo que ella, en su terreno de creación literaria, había llevado a la práctica desde sus primeras novelas: la inspiración y puesta en valor de temáticas y características propias de la tierra gallega ${ }^{93}$. Para la problemática específica de la arquitectura, la alusión a la búsqueda del "clima propio" iba más allá de los factores meteorológicos para referirse también a la consideración del paisaje histórico y las tradiciones autóctonas, ideas totalmente alineadas con la llamada a atender las peculiaridades artísticas regionales que Leonardo Rucabado y Aníbal Gónzález habían lanzado poco antes, en la ponencia presentada al VI Congreso Nacional de Arquitectos celebrado en San Sebastián en 19154. De hecho, la propia Emilia podía presumir, también en este ámbito de la arquitectura, de haberse adelantado a marcar el rumbo a seguir con la disposición general y elementos ornamentales diseñados, en colaboración con su madre $D^{a}$ Amalia de la Rúa y con el puntual asesoramiento de Vicente Lampérez, para su historicista morada de las Torres de Meirás, construida a partir de $1894^{95}$.

Los llamamientos de la Pardo Bazán y Antonio Palacios no cayeron en saco roto, ya que pocos días más tarde, a comienzos de septiembre, se convocó una reunión para concretar la idea de crear una asociación de artistas y, entre otras iniciativas, lanzar "una campaña en defensa del arte antiguo [de Galicia], cuyas joyas se pierden o maltratan lamentablemente" ${ }^{\prime 6}$. Sobre este aspecto, la ciudad de A Coruña mostraba una situación bien diferente a la de Santiago en cuanto a la problemática de la conservación de un ambiente urbano tradicional. Debido a la desventajosa comparación con Compostela se había asentado el convencimiento de que la ciudad herculina no disponía de un conjunto histórico de interés ${ }^{97}$, ya que ni la presencia de hitos monumentales ni el mantenimiento de rasgos de la ciudad del Antiguo Régimen, como las murallas o los soportales, podían servir aquí para apoyar los valores de su casco viejo ${ }^{98}$. Por el contrario, sus etapas de mayor pujanza, sobre todo durante los siglos XVIII y XIX, habían puesto las bases para una intensa renovación del caserío, hasta el punto que, en esta ya veterana dinámica de reemplazo y adición de piezas urbanas, no llegó a resultar extraña ni chocante la irrupción de las tendencias eclécticas y modernistas ya comentadas; también es necesario tener en cuenta que, a diferencia de Santiago, el emplazamiento de las construcciones modernas se había alejado en A Coruña de la Ciudad Vieja para repartirse por la Pescadería y los solares del naciente Ensanche, precisamente los sectores más característicos de la ciudad burguesa ${ }^{99}$. Incluso una solución constructiva local tan arraigada y típica como las galerías había sido hábilmente integrada por los arquitectos locales ya desde las primeras décadas del siglo XIX ${ }^{100}$, lo que sin duda favoreció la aceptación de las nuevas arquitecturas modernistas, que no sólo no prescindieron sino que revitalizaron su presencia. De hecho, ni siquiera llegó a producirse rechazo hacia las edificaciones situadas en pleno casco histórico o en sus proximidades, como se demostraría cuando tuvo lugar la ampliación del severo palacete neoclásico del marqués de San Martín de Hombreiro en la calle del Parrote, con una llamativa combinación de galería, balcón central de fundición y miradores laterales a cargo de Juan de Ciórraga (1910); o con la edificación de la vivienda en el número 1 de Puerta Real, la conocida como casa Rey (1911), bajo planos de Julio Galán Carvajal, pese a su transgresora variedad y cromatismo en los distintos materiales empleados; o con la que se situó muy próxima, en la calle Santiago $n^{\circ} 2$, la 
casa Molina, diseñada en 1915 por Rafael González Villar, en la que su ecléctica torre y cúpulín de esquina se incorporaron como nuevo mascarón de proa para aquella esquina de la Ciudad Vieja (Fig. 9).

Frente a las voces críticas que se estaban alzando en Compostela, la prensa y las autoridades de A Coruña coincidieron en valorar las nuevas construcciones como muestra de los progresos en el crecimiento y desarrollo de la ciudad ${ }^{101}$. En aras de esta modernidad no se dudó a la hora de abordar operaciones de derribo y perforación más características de la pasada centuria, como la apertura de la calle Durán Loriga, que ya había sido planteada en 1902 para unir la calle de Santa Catalina con la de Fonseca por medio de una moderna y espaciosa vía "en armonía con la higiene y el desarrollo marcado de la población", pero que sólo pudo realizarse a finales de los años veinte ${ }^{102}$. En este sentido es muy pertinente la comparación con Gijón, otra ciudad cantábrica con el mismo doble perfil industrial y turístico, donde no sólo emergieron propuestas idénticas para abrir calles acristaladas, como la calle del Agua en 1902, sino que el ambiente general, desde las ordenanzas municipales a los viajes de estudio, fue igualmente propicio para la renovación urbana y el desarrollo de la arquitectura modernista ${ }^{103}$.

En cuanto al panorama en la otra gran urbe gallega, Vigo carecía, como A Coruña, de una densidad monumental y una persistencia de elementos típicos que pudieran haber propiciado una temprana reivindicación de los valores de su casco histórico ${ }^{104}$. El intenso desarrollo de la edificación privada en el ensanche, a partir de 1876, había aliviado igualmente la presión urbanizadora sobre la zona vieja, de manera que los suntuosos palacios de piedra burgueses fueron unánimemente vistos como un signo de progreso y demostración de la vitalidad de la población. No obstante, los sucesivos proyectos de relleno portuario, desde el contenido en el Plan General de Ordenación de Manuel Fernández Soler de 1880 al previsto en 1910 por Eduardo Cabello ${ }^{105}$, sí afectaron al conjunto de viviendas de tipología

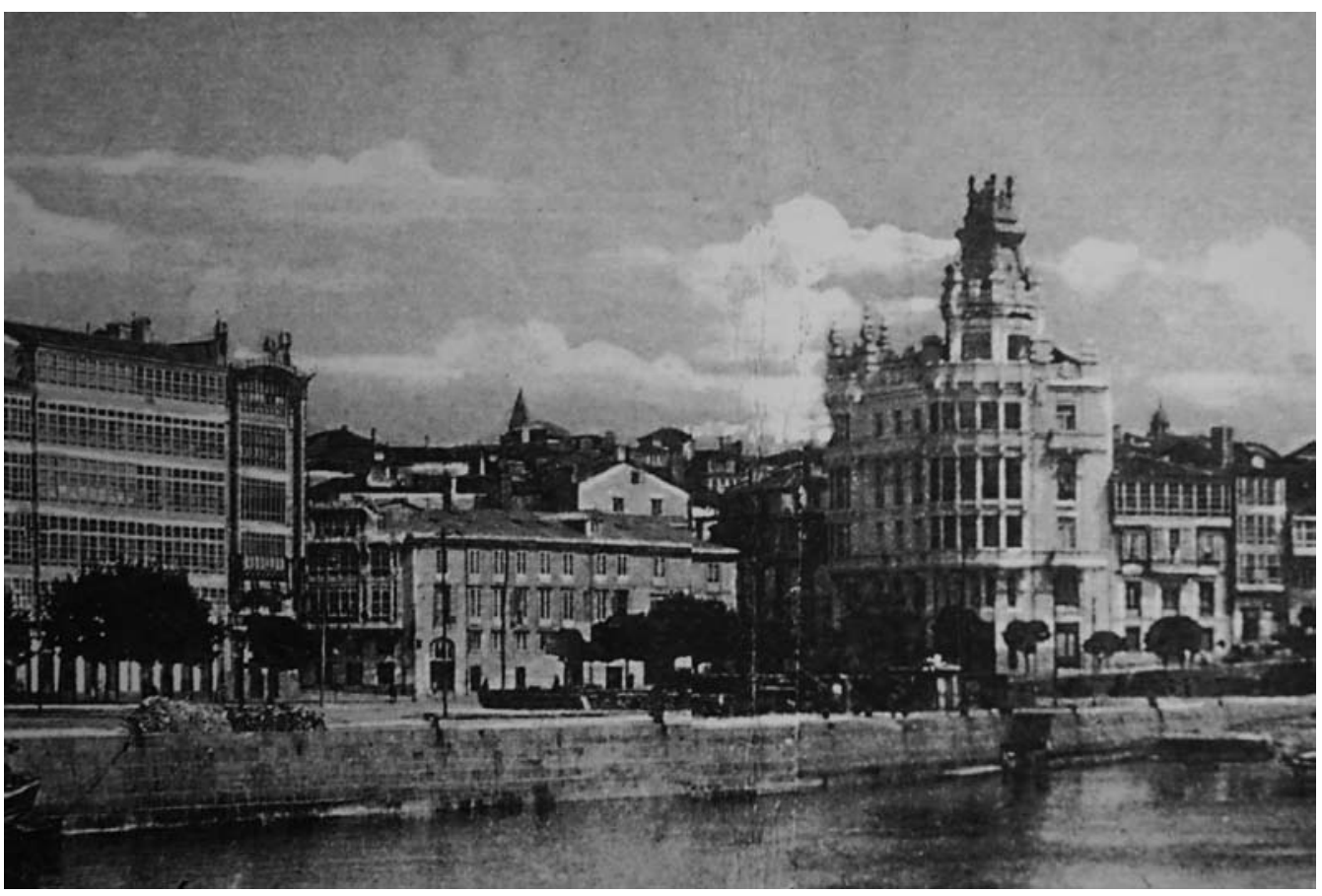

Fig. 9. Encuentro de la Marina con la Ciudad Vieja de A Coruña. A la izquierda la Casa Rey y a la derecha la Casa Molina (Catálogo de la colección de postales. Archivo Municipal, A Coruña, 1998) 
marinera de la ribera del Berbés, con soluciones de malecón, diques y dársenas que acabarían trastocando el enclave que preservaba los rasgos más típicos de la primera vinculación de Vigo con el mar, a través de las rampas y playa para el desembarco diario de la pesca, o los soportales para recoger barcas y aparejos (Fig. 10). Presentado en 1926 el proyecto definitivo para las nuevas dársenas del Berbés, aprobado oficialmente en enero de 1927, fue entonces cuando se hicieron oir las primeras voces reclamando la preservación de aquel pintoresco conjunto de arquitectura tradicional, moviendo al arquitecto municipal Jenaro de la Fuente Álvarez (1891-1963) a presentar una propuesta para conservar aquella barriada frente a la amenaza del nuevo puerto pesquero ${ }^{106}$. Ante la imperiosa necesidad de las obras portuarias, cuando Antonio Palacios redactó su utópico Plan de Extensión y Reforma Interior de Vigo (1932), pese a ser consciente del valor de aquel conjunto únicamente alcanzó a proponer la solución de trasladar las edificaciones tradicionales afectadas para crear en la zona del parque de Castrelos un "Burgo Arqueológico" 107.
Primeras actuaciones correctoras. La búsqueda de un estilo "compostelano"

En el contexto de expansión de las tendencias de arquitectura regionalista mencionadas líneas atrás, el final de la década de los años diez asistió a novedosos debates sobre las alternativas entre reforma y conservación de las "poblaciones históricas". Fueron sintomáticas las reflexiones expuestas durante el VII Congreso Nacional de Arquitectos celebrado en Sevilla en 1917, con ponencias como la presentada por Antonio Gómez Millán, en la que planteaba la preocupación por las intervenciones en los centros históricos y su continuidad o enlace con las zonas de ensanche ${ }^{108}$. Pese a que todavía era corriente aplicar estrategias de puesta en valor de los monumentos que implicaban la eliminación de construcciones secundarias, consideradas "parásitas", no se debe perder de vista que entre las conclusiones del citado congreso se recogiera ya la necesidad de formar un "índice de poblaciones" que merecieran el calificativo de "históricas" o de "carácter artístico", tanto por

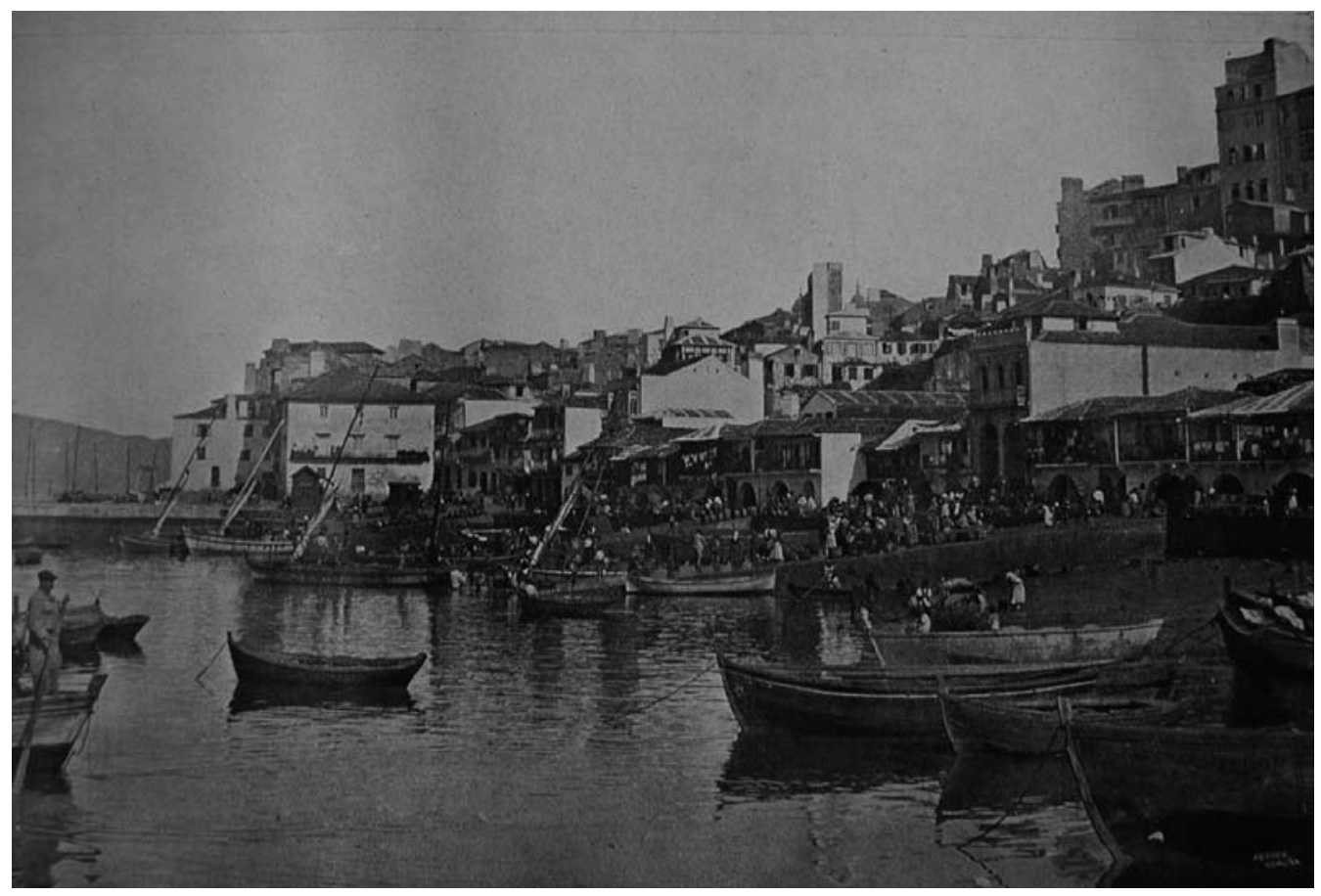

Fig. 10. Ribera del Berbés en Vigo antes de las obras portuarias (Ferrer, Portfolio Galicia, 1904) 
la calidad de sus conjuntos monumentales como por su peculiar disposición urbana. Esta mentalidad conservacionista se reforzó además gracias a las ideas defendidas por Leopoldo Torres Balbás desde su ponencia en el VIII Congreso Nacional de Arquitectos (Zaragoza, 1919), al cuestionar las operaciones de modernización que, con la apertura de calles rectas, estaban cortando el corazón de las viejas ciudades y destruyendo su paisaje urbano ${ }^{109}$.

En el ámbito local de Compostela, la sensibilización hacia los valores de la ciudad histórica encontró un inesperado estímulo en el proyecto para levantar un monumento a Montero Ríos, que había dado sus primeros pasos desde mayo de 1914, siendo alcalde el catedrático de Medicina Luis Blanco Rivero ${ }^{110}$. Pese a que inicialmente se habían descartado las principales plazas que rodeaban la Catedral, como la del Hospital o la de la Quintana ${ }^{111}$, fue finalmente la actual plaza del Obradoiro la que acogió, tras la inauguración celebrada el 30 de julio de 1916, una estatua que se mantuvo en ese polémico emplazamiento hasta 1928, cuando fue reubicada en la plaza de Mazarelos. Entre las diferentes voces que por entonces se opusieron a lo que se calificó de "profanación artística", desde Valle-Inclán a Castelao pasando por Vicente Lampérez, Elías Tormo o Rafael González Villar, es preciso destacar la iniciativa de un grupo de vecinos al remitir un escrito a la Dirección General de Bellas Artes para que la plaza del Obradoiro fuera declarada Monumento Nacional, intentando sin duda abortar la proyectada instalación del monumento ${ }^{112}$. Esta declaración como monumento nunca llegó a tramitarse, quedando postergada tanto por los enfrentamientos políticos que se ocultaban tras la oposición al monumento a Montero Ríos como por las limitaciones de la vigente Ley de Monumentos Arquitectónicos Artísticos, aprobada el 4 de marzo de 1915 pero todavía muy restrictiva en su decimonónica atención al monumento singular.

La vía más operativa para identificar y preservar los rasgos típicos de la población salió a la luz en marzo de 1919, con ocasión de la solicitud de obras para el futuro Salón Teatro: un local promovido por la asociación católica Liga Mutua de Señoras, para el que se pensaba derribar un barroco caserón existente en el número 34 de la rúa Nova (Fig. 11). Conocedor de esta iniciativa, y de la ecléctica fachada prevista para el nuevo recinto, de la que sobresalía llamativamente el volumen en cemento de la cabina de proyecciones, el concejal Manuel Villar Iglesias ${ }^{113}$, ya mencionado páginas atrás, intervino en la sesión municipal del 26 de marzo para pedir a la Comisión de Obras:

... que se sirva hacer estudio de los preceptos de las Ordenanzas municipales a fin de modificarlos con la orientación conducente a conservar el carácter típico de las construcciones urbanas dentro del casco de población para que no desdigan de la Arquitectura que sella y refrenda el valor artístico de nuestro pueb/o ${ }^{114}$.

Es posible que este interés personal de Villar Iglesias por la conservación de una imagen urbana típica se hubiera despertado durante sus años de especialización médica en el extranjero, puesto que consta que en 1910 se desplazó a Francfort y París para sendas estancias de formación ${ }^{115}$. Lo cierto es que su postura introdujo otro relevante precedente para la importancia de conservar el "sello característico de época" del casco viejo compostelano, si bien, como ya se ha comentado, no estuvo exenta de contradiccio-

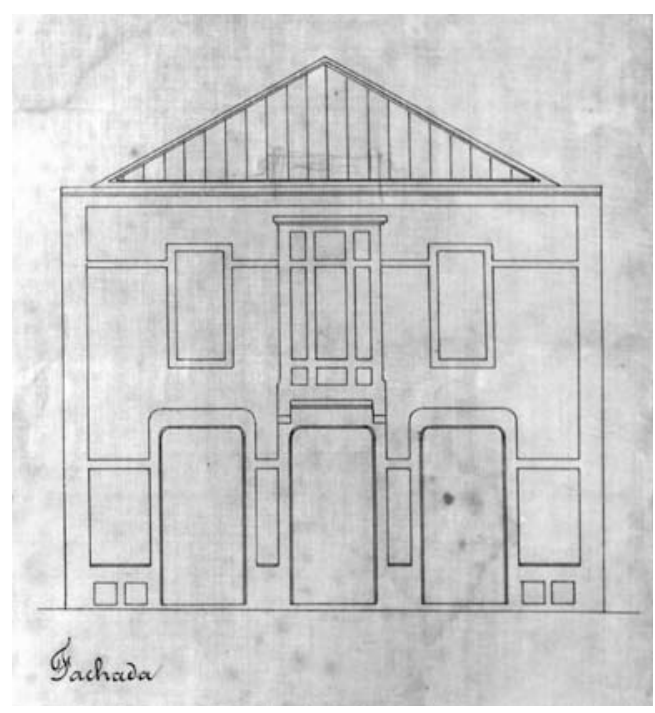

Fig. 11. Fachada proyectada para el Salón Teatro en la rúa Nova. J. López de Rego, 1919 (AHUS. Fondo municipal. Licencias de obras) 
nes cuando, a finales de aquel mismo año, Villar Iglesias propugnó la drástica reforma del sector oeste de la plaza del Toral para reubicar la estatua de Montero Ríos, priorizando en este caso la oportunidad para generar empleos y mejorar los accesos a la ciudad.

Con respecto a los planos para edificar el SaIón Teatro, no fue sólo el concejal Villar Iglesias quien objetó su falta de armonización con las viejas edificaciones de la calle, puesto que también el arquitecto municipal, Mariano Fernández Ragel, informó que los planos firmados por Jesús López de Rego eran de "pobre de ornamentación", o al menos poco acorde con un edificio de cierta categoría ${ }^{116}$. De hecho, aunque el proyecto obtuvo un dictamen favorable, desde su responsabilidad hacia el ornato público que era necesario respetar en una ciudad histórica el técnico municipal recomendaba la reforma y mejora de aquella propuesta de fachada, sugiriendo que sería conveniente un tipo de estética inspirada en la arquitectura tradicional compostelana:

Si tal mejora prevalece, resultaría agradable una composición Arquitectónica de estilo Compostelano, puesto que armonizaría con el resto de las construcciones antiguas de la Rúa Nueva ${ }^{117}$.

Concedida la licencia de obras ${ }^{118}$, la fachada adoptó finalmente una solución más conservadora e integrada en la calle, manteniendo y regularizando los huecos y balcón del inmueble preexistente (Fig. 12). Así se daba un pequeño pero significativo paso hacia la preservación de las construcciones tradicionales y el carácter típico del casco histórico de Compostela, validando la nueva visión contemplativa del paisaje urbano ${ }^{119}$. Por otra parte, la aplicación de esta primera corrección vino a coincidir en el tiempo con la difusión del proyecto de Antonio Palacios para el nuevo ayuntamiento de Porriño: un diseño que desde el verano de 1918 estaba siendo ampliamente publicitado y saludado como el punto de partida para la regeneración artística de Galicia a partir de su tradición arquitectónica ${ }^{120}$. Con este preámbulo, aunque fuera limitado a la recuperación ambiental de un fragmento urbano, la concreción del "estilo Compostelano" al que aludían Villar Iglesias y Fernández Ragel, inspirado en la arquitectura del barroco de placas y de los pazos, no tardaría mucho tiempo en aflorar, como se pudo comprobar gracias a las edificaciones públicas y privadas levantadas desde la década de los años veinte ${ }^{121}$.

Durante este mismo período, la conservación y mejora de la estética urbana encontró un acérrimo defensor en Constantino Candeira (18921962), arquitecto municipal de Santiago desde enero de 1924 a febrero de $1930^{122}$. Junto a las restauraciones que dirigió en monumentos como el Hospital Real o San Martín Pinario, Candeira mostró un temprano convencimiento sobre la necesidad de reformar las Ordenanzas municipales de Santiago en el mismo sentido prescriptivo que ya había propuesto Villar Iglesias, y así introducir medidas para proteger el ambiente urbano a imitación de otras ciudades europeas, entre las que citaba, como hiciera Emilia Pardo Bazán, a Nuremberg ${ }^{123}$. Su insistencia en revisar el marco legal permite igualmente suponer que tuviera información sobre las actuaciones de Gustavo Giovannoni, en especial en la redacción de los planes reguladores para la conservación de conjuntos y fragmentos urbanos en Roma, Ostia, Bari o Bérgamo ${ }^{124}$. Por la claridad y persistencia en la defensa de estas ideas, en 1926

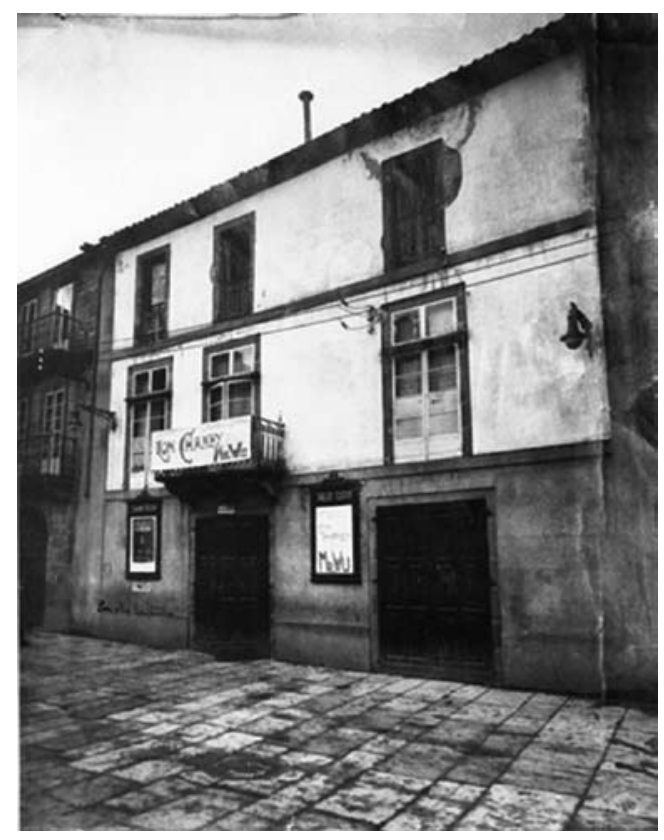

Fig. 12. Fachada del Salón Teatro, 1928 (AHUS. Fondo municipal. Licencias de obras) 
fue destacado por Otero Pedrayo como uno de los primeros en percibir la ciudad de Santiago de Compostela como algo más que un conjunto de monumentos, o incluso más que una ciudad-museo, alcanzando a entenderla como un auténtico "ser vivo", sensible a los destrozos que podían provocar las "tendencias modernizantes", entre las que citaba realidades ya examinadas como el desarrollo de los bajos comerciales y sus escaparates, o la obsesión de arquitectos e ingenieros por la rigurosidad geométrica en las alineaciones y ensanches de calles ${ }^{125}$.

Aunque no consiguiera reformar las Ordenanzas municipales, el empeño personal de Candeira sí encontró el apoyo del alcalde José DíazVarela y Losada ${ }^{126}$, en el contexto de los años del régimen de Primo de Rivera, cuando se hizo más evidente la sensibilidad hacia la preservación de un conjunto histórico ya apreciado como un catálogo de memoria visual y, por ello, activo fundamental para los nuevos deseos de promoción turística de la ciudad ${ }^{127}$. Entre las limitadas realizaciones de aquel período, algunas dejaron una notable impronta en la estética urbana, como el bando que ordenaba dejar al descubierto la cantería granítica en las viviendas donde estuviera caleada o tapada por un revoco de cemento pintado, o la nueva pavimentación de la plaza de la Quintana antes mencionada (Fig. 13). De acuerdo con las actas de la Comisión Municipal Permanente, el alcalde Díaz-Varela contó también para su objetivo de "restablecer el aspecto artístico" del casco viejo con el explícito apoyo de otros miembros de la corporación entre los que destacaron los concejales Jesús López de Rego, arquitecto y empresario, o el escultor Maximino Magariños Rodríguez, dueño del taller de carpintería más importante de la ciudad ${ }^{128}$. Magariños fue precisamente el promotor, en vísperas de las fiestas del Apóstol de 1925, de una moción para modificar el artículo 77 de las Ordenanzas municipales en el sentido de fijar el estilo de arquitectura a seguir "para las construcciones en nuestras Rúas y calles típicas", de acuerdo con unos modelos de viviendas que el Ayuntamiento seleccionaría tras la celebración de un concursoexposición pública de proyectos. El fin perseguido no era otro que evitar la repetición de casos como el ocurrido con el Salón Teatro, lo que además se completaba con una primera sugerencia de figura de protección enunciada como declarar "Monumentos locales" algunas de las rúas típicas del casco histórico. Esta moción fue apoyada por el alcalde Díaz-Varela, insistiendo en la utilidad del concurso de proyectos como medio para definir un tipo de "Casa Gallega", con versiones rural y urbana, susceptibles de adaptarse para orientar las nuevas construcciones en Compostela ${ }^{129}$, estableciendo un premio para estas nuevas edificaciones, y, lo más importante, delimitando la zona del casco viejo a proteger como "Monumento-Histórico":

... una zona que se considerará como Monumento-Histórico, para la cual se solicitaría del Gobierno la declaración de zona de monumentos de interés artístico e histórico, y dentro de la cual las construcciones y las reformas de calles habrían de sujetarse necesariamente a las bases arquitectónicas y de urbanización que el mismo Ayuntamiento hubiese aprobado como compatibles con el carácter tradicional de la dicha zona, que encerraría las más típicas calles de la ciudad ${ }^{130}$.

Todos estos interesantes precedentes se vieron afectados por la inestabilidad política, lo que

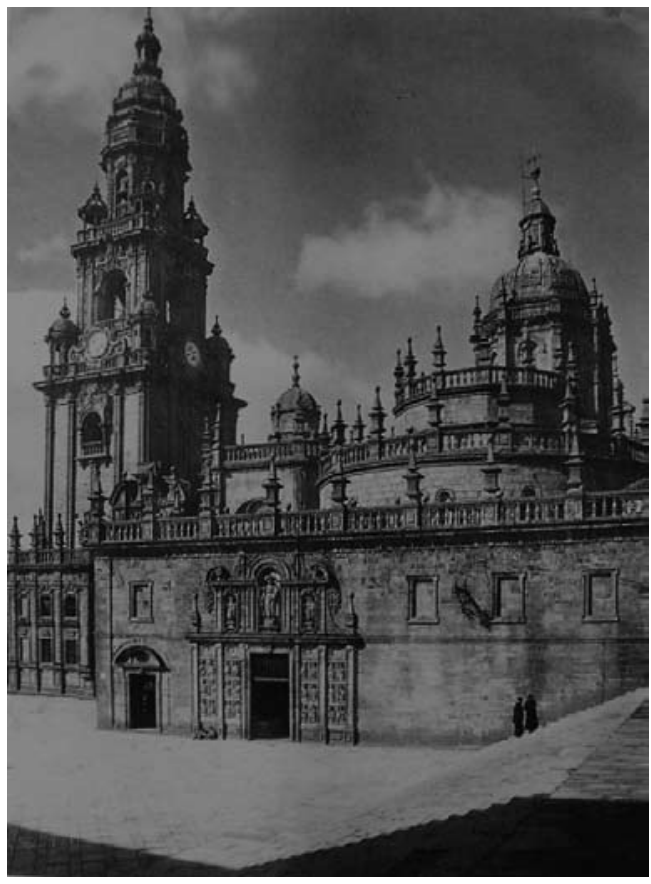

Fig. 13. Plaza de la Quintana con el pavimento diseñado por Constantino Candeira (Ksado) 
explica que hasta la década de los años treinta no se produjeran mayores avances, ahora en la etapa desde la II República al comienzo del régimen franquista131. Como nuevos elementos que fueron entrando en acción cabe destacar la presencia como teniente de alcalde del activo líder obrero José Pasín (1878-1960), escultor comprometido con la preservación de los soportales, que no veía incompatibles con otras mejoras urbanas, o la instalación en Compostela de José María Banet Díaz-Varela (1903-1985), nombrado nuevo arquitecto municipal desde el año 1931, primero interinamente y ya con la plaza en propiedad desde $1932^{132}$. El alcance de los informes y observaciones de Banet sobre las nuevas construcciones en el casco histórico compostelano guarda estrecha relación con su propio ejercicio profesional, ya que desde aquellos comienzos de los años treinta fue capaz de mantener una equilibrada y singular andadura entre los modelos racionalistas, reservados para las nuevas edificaciones en el ensanche, y el aprecio por el barroco compostelano, siendo este estilo al que acudió preferentemente para viviendas situadas en pleno corazón de la ciudad, como en el proyecto para la rúa do Vilar $n^{\circ} 11$ (1933) (Fig. 14) $)^{133}$.

Faltaba que esa misma sensibilidad hacia el ambiente urbano fuera asumida por los responsables municipales, con independencia de su adscripción política, lo que pudo comprobarse desde noviembre del año 1934 gracias al relevo en la alcaldía, que pasó a ser ocupada por Francisco Vázquez Enríquez, y el nombramiento como concejal del comandante de ingenieros Braulio Amaro Gómez, quien se hizo cargo de la Comisión de Ensanche, reforma interior y Residencia de estudiantes ${ }^{134}$. La primera moción presentada desde esta Comisión, ya en el mes de diciembre, consistió en una propuesta para que, de acuerdo con el informe favorable del arquitecto municipal, se anularan todos los planes de alineaciones vigentes sobre el casco histórico, reconociendo el grave daño que estaban causando al "carácter especialísimo de Compostela", de manera que sólo se mantuvieran los que al implicar mínimas modificaciones no afectaran a esa estética peculiar de la ciudad ${ }^{135}$. El propio concejal Amaro Gómez expuso con rotundidad que esta era la primera de una serie de modificaciones para dejar sin efecto la obsesión por las calles rectas y la desaparición de soportales vigentes desde el urbanismo decimonónico. Renovando aspiraciones conservacionistas ya aludidas, el concejal Villar Pellit, médico odontólogo, añadió "que se gestionase la declaración superior de ciudad monumental para Compostela, para evitar así que según el cambio de los ayuntamientos, así cambien los criterios y se autoricen obras que abiertamente pugnan con el carácter artístico de esta ciudad; lo cual no ocurrirá así, declarada ciudad monumental, para toda obra que pudiera afectar a ese carácter hubiera que obtener autorización superior". La propuesta, que hubiera derivado en la primera declaración de una ciudad monumental de España, fue desde luego apoyada por el concejal Amaro Gómez, aunque poco más tarde se abandonó, tardando en alcanzarse, como ya se indicado, hasta el año $1940^{136}$.

La paralela tramitación del expediente para construir la "Rúa de Galicia", una idea de acceso monumental a la plaza del Obradoiro que Antonio Palacios había ofrecido en 1932 al Ayun-

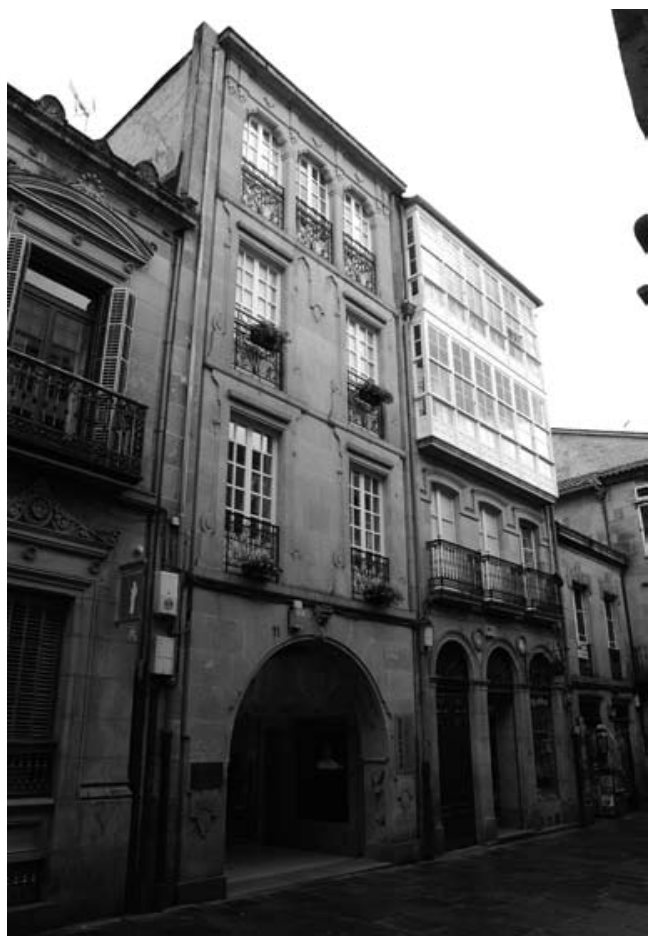

Fig. 14. Edificio en rúa do Vilar, 11. José María Banet, 1933 (Autor) 
tamiento compostelano, acaparó la atención de la corporación local durante los años 1935 y $1936^{137}$, junto al desarrollo de las obras de la Residencia de Estudiantes y algunas restauraciones de monumentos, como las dirigidas por Alejandro Ferrant en la colegiata de Sar y el palacio de Gelmírez ${ }^{138}$. Es posible que en relación con estas actuaciones de Palacios y Ferrant se reactivara el interés por los valores artísticos del casco viejo, puesto que vuelve a detectarse en el año 1935 con motivo de una solicitud para rasgar algunos huecos en la fachada de una casa situada en el número 24 de Casas Reales. La obra, que no hubiera suscitado ningún reparo décadas atrás ${ }^{139}$, fue ahora motivo de tensas discusiones, rechazándose la pretensión del propietario en la sesión municipal del 20 de abril, al priorizarse, de acuerdo con el informe del arquitecto municipal, el objetivo de no perjudicar la estética tradicional de aquella construcción y tramo de la calle. Ante las alegaciones presentadas por el promotor, ya en julio se volvió a debatir este asunto, renovándose por parte de la Comisión de Fomento la intención de "conservar en cuanto sea dable el sabor de la construcción compostelana", si bien finalmente se aceptó que la casa en sí no tenía gran valor y que ya se habían aprobado obras similares, por lo que se rectificó el primer dictamen negativo; con todo, fue necesario llegar a una votación para aprobar esta concesión de licencia, durante la cual se produjo el abandono del salón de plenos de tres concejales, que hicieron así patente su disconformidad por no mantenerse el informe inicial del técnico ${ }^{140}$.

La percepción de que las Ordenanzas municipales y alineaciones decimonónicas se habían quedado obsoletas, sin responder ni a las nuevas necesidades ni a la preocupación por la conservación del ambiente urbano, dio lugar a un nuevo intento para su eliminación en $1936^{141}$. Sin embargo, no fue hasta 1937, tras un nuevo debate sobre la conservación de soportales, en este caso al tramitarse un proyecto para reformar la casa número 43 de la rúa do Vilar, cuando a instancias de Fermín Zelada Varela, doctor en Farmacia y concejal al frente de la Comisión de Fomento, se abordó la derogación de la alineación que pesaba sobre esta calle desde el año $1871^{142}$. La moción de la Comisión de Fomento antepuso entonces el criterio de la "conservación del carácter arquitectónico de Santiago" al reaparecer la cuestión clave de si debían mantenerse o no los soportales de esa y otras calles del casco viejo. Tras pedir informes a varios arquitectos en ejercicio, entre los que estuvieron Jesús López de Rego, José María Banet, Joaquín Vaquero Palacios, por entonces encargado del proyecto para la nueva plaza de abastos, Jenaro de la Fuente Álvarez, responsable de la Residencia de Estudiantes, y Eduardo Rodríguez-Losada Rebellón, todos coincidieron en la conveniencia de dejar sin efecto la alineación vigente desde el siglo XIX, para que así la rúa do Vilar pudiera ayudar a conservar "el grandísimo valor arquitectónico y monumental de Compostela". Asumiendo estas opiniones, y pese a las protestas de algunos vecinos que ya habían visto como se derribaban sus soportales, la corporación municipal aprobó por unanimidad la derogación de la alineación decimonónica ${ }^{143}$. Se abría así una nueva dinámica, profundizada y consolidada a partir de los años cuarenta, para el mantenimiento y la recuperación de la estructura e imagen acordadas como típicas de la ciudad histórica. 


\section{NOTAS}

* La realización de este trabajo se inscribe en el Proyecto de Investigación financiado "La visión del artista. Ciudad y arquitectura en Galicia desde la Edad Media hasta la irrupción de la fotografía", Ministerio de Ciencia e Innovación, Código HAR2011-24968, IP Alfredo Vigo Trasancos.

1 Boletín Oficial del Estado, $n^{\circ}$ 109, 18 abril de 1940, pp. 2657-2658. Firmado por Francisco Franco, siendo José Ibáñez Martín ministro de Educación Nacional, el decreto formó parte de un grupo de medidas que afectaron a distintos aspectos de la protección del patrimonio, como la reorganización de los patronatos de los museos nacionales de Arte moderno y de Escultura, el Servicio del Catálogo Monumental, o la creación de una Residencia y Museo en el Palacio de Carlos V de Granada.

2 De hecho, al igual que ocurrió con los "Monumentos nacionales" declarados desde el siglo XIX, los primeros conjuntos urbanos reconocidos en España pasaron a ser protegidos como "conjuntos históricos" desde la normativa específica aprobada con la Orden del 20 de noviembre de 1964, incluyéndose más tarde en la nueva categoría de los bienes de interés cultural por la primera disposición adicional de la citada LPHE de 1985; en cuanto a la Lei do Patrimonio Cultural de Galicia de 1995, incorporó también como bienes de interés cultural todos los ya declarados con anterioridad para su ámbito territorial, en este caso bajo la denominación de "Conxunto histórico". F. Castro Allegue, Código del Patrimonio Cultural Gallego, Xunta de Galicia, 2005, pp. 66 y 240.

3 Sus reflexiones sobre "El quietismo estético" comienzan, precisamente, con una poética evocación de las ciudades de Toledo y Santiago: R. del Valle-Inclán, La Lámpara maravillosa (1912), Reed. en Obra Completa. I. Prosa, Espasa Calpe, Madrid, 2002, pp. 1951-1954.

${ }^{4}$ La Ley de 13 de mayo de 1933 sobre defensa, conservación y acrecentamiento del patrimonio históricoartístico nacional contemplaba ya que junto a los "Monumentos nacionales" fuera posible proteger "los conjuntos urbanos y los paisajes pintorescos" (art. 3); profundizando en lo dispuesto por el Decreto Ley de 09/08/1926, que aludía genéricamente a "edificaciones o conjuntos de ellas", la norma de 1933 mencionaba específicamente conjuntos urbanos y rústicos como "calles, plazas, rincones, barrios, murallas, fortalezas, ruinas fuera de las poblaciones que por su belleza, importancia monumental o recuerdos históricos puedan declararse incluidos en la categoría de rincón, plaza, calle, barrio o conjunto histórico-artístico" (art. 33). Además, por el Reglamento de 16 de abril de 1936 para la aplicación de esta Ley del Tesoro Artístico Nacional se estableció que "La Junta Superior del Tesoro Artístico procederá a formar una lista de ciudades, villas y pueblos cuyas agrupaciones urbanas, total o parcialmente, tengan señalado interés artístico, histórico o pintoresco...", lo cual se tendría en cuenta especialmente para la realización de planos de reforma interior y ensanche (art. 29). C. Barrero Rodríguez, La ordenación jurídica del Patrimonio Histórico, Civitas, Madrid, 1990, pp. 66-75; y J. Fariña Tojo, La protección del patrimonio urbano. Instrumentos normativos, Akal, Madrid, 2000, pp. 17-23.

${ }^{5}$ En el caso de la ciudad de Santiago de Compostela, los primeros monumentos declarados dentro del actual perímetro o entorno de protección fueron la iglesia de Santa María la Real del Sar, (Gaceta de Madrid, 17 de agosto de 1895), la iglesia de San Francisco (Ley del 16 de agosto de 1896), y, por supuesto, la Catedral (Gaceta de Madrid, 25 de agosto de 1896). Tras estas primeras declaraciones, hasta comienzos del siglo XX no continuó incrementándose la lista de monumentos dentro del casco histórico, sumando a la arquitectura medieval obras renacentistas y barrocas como la capilla del Hospital Real y la iglesia de Santo Domingo de Bonaval (ambos en Gaceta de Madrid, 1 de enero de 1913), y, ya incluidos en el macro decreto de la II República aprobado en 1931, el Hospital Real y el palacio de Gelmírez (Decreto del Ministerio de Instrucción Pública y Bellas Artes del 3 de junio de 1931, Gaceta de Madrid, n 155, 4 de junio de 1931).
${ }^{6}$ Las limitadas novedades urbanísticas introducidas en esta Ley Municipal de 31 de octubre de 1935 se recogen en M. Bassols Coma, Génesis y Evolución del Derecho Urbanístico Español, Editorial Montecorvo, Madrid 1973, p. 520-522.

7 La exaltación de Toledo como "ciudad-relicario" de inaplazable recuperación por su valor histórico para el "espíritu imperial de la Patria" aparece recogida en un texto de 1939, buena muestra de las utilizaciones de la historia para legitimar el nuevo proyecto político franquista, como analizan E. Almarcha Núñez-Herrador e I. Sánchez Sánchez, "El Alcázar de Toledo: La construcción de un hito simbólico", Archivo secreto, n 5, 2011, pp. 393416; y M.I. Cabrera García, "El pasado como condición: discurso artístico e identidad nacional durante el primer franquismo" en Historia, restauración y reconstrucción monumental en la posguerra española, M. P. García Cuetos, M.E. Almarcha Núñez-Herrador, A. Hernández Martínez, Coords., Abada editores, Madrid, 2012, pp. 41-64.

${ }^{8}$ Decreto $n^{\circ} 325$, "Reconociendo como Patrón de España al Apóstol Santiago y declarando día de Fiesta Nacional el día 25 de julio de cada año", BOE 22/07/1937.

${ }^{9}$ Escoltada por el arzobispo Muñiz de Pablos, los obispos de Lugo y Mondoñedo, el comandante militar de la Plaza, los concejales del Ayuntamiento y el presidente de la Archicofradía del Apóstol, para completar la puesta en escena se revistió la urna con la bandera nacional, colocando sobre el anda los atributos de capitán general: fajín, sable y bastón de mando. "La brillante solemnidad de ayer. La urna que encierra los sagrados restos del Apóstol Santiago recorrió en triunfo las calles de Compostela", El Eco de Santiago, 31/08/1936, p. 1. Como único precedente para esta procesión de las reliquias apostólicas, en 1885, tras el redescubrimiento y autentificación de esos mismos restos, el Papa León XIII había autorizado un recorrido urbano semejante. A. Rodríguez González, "Notas para a historia de Compostela (1879-1975)" en Compostela na historia. RedescubrimentoRexurdimento, Cat. Exp. Casa da Parra, Santiago, 1999, pp. 25-36. 
${ }^{10}$ En su respuesta, el arzobispo Quiroga Palacios equiparó a Franco con las diferentes dinastías que, desde los monarcas asturianos, habían protegido el santuario del Apóstol, ensalzándolo como "elegido por Dios" para preservar la confesionalidad católica del Estado: "Ofrenda del Jefe del Estado al Patrón de España en Santiago de Compostela", ABC, 27/07/1954, pp. 15-18. La conexión entre este acto de 1954 y las paralelas intervenciones para la recuperación del patrimonio monumental y proyección del Camino de Santiago fueron oportunamente destacadas por B. Castro Fernández, Francisco Pons Sorolla y Arnau, arquitecto-restaurador: sus intervenciones en Galicia (1945-1985), Tesis Doctoral, Universidad de Santiago de Compostela, 2006, pp. 161-163.

${ }^{11}$ Los antecedentes de esta consideración patrimonial han merecido, hasta la fecha, escasa atención en los estudios sobre las ciudades gallegas. Una excepción, apuntando las primeras medidas legales aprobadas en el siglo $X X$, se encuentra en las consideraciones para este mismo ámbito de J.R. Soraluce Blond, Cascos históricos de Galicia, Librería Arenas, A Coruña, 2011, pp. 11-15.

${ }^{12}$ El papel de estas agresiones a la hora de activar la reacción que dio lugar a las primeras intervenciones estatales de salvaguardia fue destacado ya desde la pionera y completa visión de I. Ordieres Díez, Historia de la restauración monumental en España (1835-1936), Ministerio de Cultura, Madrid, 1995, pp. 24-34; y por F. Hernández Hernández, El patrimonio cultural: la memoria recuperada, Trea, Gijón, 2002, pp. 89103. En Galicia, como análisis sobre los gravísimos daños sufridos por el patrimonio artístico religioso, con especial atención a los inmuebles urbanos, véase J.A. Sánchez García, "Una década trágica para el patrimonio gallego. De la Desamortización a las Comisiones de Monumentos", Quintana, n 3, 2004, pp. 123-151.

13 Sobre los procesos de "aislamiento" de monumentos restaurados en España durante el siglo XIX, especialmente las principales catedrales, véase I. González-Varas Ibáñez, Restauración monumental en España durante el siglo XIX, Colegio Oficial de Arquitectos de León, 1996, pp. 248-257.

${ }^{14}$ F. Choay, Alegoría del patrimonio, GG, Barcelona, 2007, p. 163.

15 En las ciudades españolas, la Real Orden del 25 Julio de 1846 estableció la obligación de levantar un plano geométrico en todas las capitales de provincia y "poblaciones de crecido vecindario", con sus arrabales y paseos, a escala 1:1250. Dicho plano se concibió como un instrumento de reforma interior, complementario a las Ordenanzas municipales, en el que se debían marcar las rectificaciones de calles y plazas necesarias. Desde 1859 estos planos generales de alineaciones, motivados por razones de "conveniencia pública y salubridad", se hicieron obligatorios para todas las poblaciones de más de 8.000 habitantes, pese a lo cual su incidencia fue muy limitada debido a los conflictos con los intereses de los propietarios. Bassols Coma, op. cit., 101-110; J. Oliveras Samitier, "Poder municipal y urbanismo en el siglo XIX", en Ciudad y Territorio, n 94, 1992, pp. 79 a 92.

${ }^{16}$ Una mirada contemplativa que I. González-Varas engloba también bajo un tipo de reacción "culturalista", identificable a nivel europeo en un variopinto abanico de eruditos locales, artistas, escritores, estudiosos y aficionados a las artes, todos compartiendo el interés para restituir la identidad de las ciudades históricas amenazada ante el impacto de la industrialización. I. González-Varas Ibáñez, Conservación de bienes culturales. Teoría, historia, principios y normas, Cátedra, Madrid, 1999, pp. 356-357. La conexión de esta misma mirada con las representaciones artísticas y fotográficas de parajes urbanos, que podría apoyarse en las vistas captadas por Enrique Mayer, Carlos Sobrino, Castro Gil, Méndez Pena, Carlos Maside, Pedro Ferrer, Villar Martelo o Cao Moure, entre otros, tendría entidad suficiente para abordar otra investigación complementaria de la que ahora nos ocupa.

17 Otra vez dentro de un marco común a todo el ámbito europeo, ya desde la Revolución francesa, superada la vandálica oleada de destrucciones de los años 1792 y 1793, se sentaron las bases para lo que Choay bautizó como la etapa de "consagración del monumento histórico" a partir de 1820. Choay, op. cit., pp. 98-132.

${ }^{18}$ En especial Ruskin con sus críticas a la destrucción de los conjuntos de arquitectura tradicional en ciudades como Rouen, tras la experiencia de sus viajes por Francia que señala Choay, op. cit., pp. 124-125 y 165-166. Sin embargo, la difusión y conocimiento de la obra de John Ruskin fue muy tardía en España, como lo prueba que, para Cataluña, no fuera hasta el año 1900, con motivo de su fallecimiento, cuando se detecten unos primeros textos sobre su ideario, acompañados pronto de las primeras traducciones de sus obras, según demuestra la exhaustiva investigación de J. Ganau Casas, Els inicis del pensament conservacionista en I'urbanisme català, Publicacions de l'Abadia de Montserrat, Barcelona, 1996, p. 165.

${ }^{19}$ Vicente Lampérez fue uno de los primeros historiadores de la arquitectura española que, siguiendo el modelo de Viollet, comenzó a interesarse por el estudio del caserío medieval, destacando lo pintoresco de estos conjuntos en contraste con la mezquindad de las calles. Su análisis de la estructura de las ciudades medievales españolas clasificaba esas construcciones dentro de la arquitectura privada, bajo las categorías de urbana y señorial, ilustrando los comentarios con fotografías de fachadas y algunas plantas para mostrar la distribución interior. V. Lampérez y Romea, Las ciudades españolas y su arquitectura municipal al finalizar la Edad Media, discurso leído por el IImo. Sr. D. Vicente Lampérez y Romea... y contestación del Excmo.Sr.D. Enrique M. Repullés y Vargas el día 20 de mayo de 1917, Real Academia de Bellas Artes de San Fernando, Madrid, 1917, pp. 31-40; y del mismo Arquitectura civil española de los siglos I al XVIII, Saturnino Calleja, Madrid, 1922.

${ }^{20}$ Sobre el utilitarismo y falta de inspiración artística de las "casas de alquiler" modernas disertaba en 1899 Arturo Mélida, entre otros aspectos de la decadencia de la arquitectura española, en su discurso de recepción en la Academia de Bellas Artes de San Fernando. Citado por A. Isac, Eclecticis- 
mo y pensamiento arquitectónico en España. Discursos, revistas, congresos, 1846-1919, Diputación Provincial de Granada, 1987, p. 97.

${ }^{21}$ En este sentido fue decisiva la novela Bruges-la-Morte, de Georges Rodenbach (1892), por su crudo retrato de una situación comparable a muchas ciudades monumentales europeas, en las que el pasado esplendor se contraponía al languidecimiento del siglo XIX. Sobre el protagonismo de esta visión urbana en la novela de Rodenbach cabe apuntar, además, la circunstancia, hasta entonces inusual, de que la primera edición de la obra apareciera ilustrada con fotografías de la ciudad, que se presentaba como otro protagonista más de la novela. Emilia Pardo Bazán comentó ya esta novela, en "La vida contemporánea", La llustración Artística, No 1076, 11/08/1902, p. 522.

${ }^{22}$ La determinante aportación de la época barroca para la imagen tradicional de las ciudades españolas, en contraste con la limitada huella del neoclasicismo, e incluso del siglo XIX si exceptuamos la novedad de los ensanches, fue señalada ya en su momento por A. Bonet Correa, Morfología y ciudad. Urbanismo y arquitectura durante el Antiguo Régimen en España, GG, Barcelona, 1978, pp. 22-25; y del mismo "Las ciudades españolas del Renacimiento al Barroco" en Vivienda y urbanismo en España (VV.AA.), Banco Hipotecario de España, Barcelona, 1982, esp. pp. 123-124. En el caso de Santiago de Compostela se ha contabilizado que conserva actualmente todavía un 19,1\% de viviendas construidas en época barroca, porcentaje que lógicamente era mucho mayor a finales del siglo XIX, puesto que las nuevas edificaciones del XIX a comienzos del XX conforman un 31,5\% del conjunto residencial actual: J.A. Aldrey Vázquez, J. Formigo Couceiro, O casco histórico de Santiago de Compostela, características demográficas e morfolóxicas, Universidade de Santiago de CompostelaIDEGA, 1999, p. 44.

${ }^{23}$ Al margen de las propias palabras de Haussmann, empleando la aludida metáfora sobre el cuerpo enfermo de París, las valoraciones sobre la relevancia del nuevo orden espacial instaurado tras su actuación acudieron, ya entre sus contemporáneos, a la idea de la "destrucción creadora" como motor necesario para la transformación de un colapsado centro urbano. G. Piccinato, "El problema del centro histórico" en Los centros históricos. Politica urbanistica y programas de actuación, F. Ciardini y P. Falini, eds., GG, Barcelona, 1983, pp. 15-18; R. Sennet, Carne y piedra. El cuerpo y la ciudad en la civilización occidental, Alianza Editorial, Madrid, 1997, pp. 350-354; y J. A. Sánchez de Juan, "La 'destrucción creadora': el lenguaje de la reforma urbana en tres ciudades de la Europa mediterránea a finales del siglo XIX (Marsella, Nápoles y Barcelona)", Scripta Nova. Revista Electrónica de Geografía y Ciencias Sociales, $N^{\circ}$ 63, 1 de mayo de 2000 [Acceso: 07/03/2013].

24 Como reconocerá el propio Haussmann, en un texto escrito para recusar la acusación de destrucción irrespetuosa del viejo París, reproducido por Choay, op. cit., p. 161. En todo caso, como también afirma Choay, las ocasionales manifestaciones de nostalgia por la pérdida de las ciudades antiguas no derivaron entonces en el caso de Francia, y esto es desde luego muy revelador, en unas demandas de protección patrimonial comparables a las que disfrutaban los monumentos históricos.

${ }^{25}$ La asociación entre el progreso urbano y desaparición de aquellos molestos cinturones de piedra es evidente en la expresiva publicación del médico catalán P.F. de Monlau, ¡Abajo las murallas! Memoria sobre las ventajas que a Barcelona y especialmente a su industria, la demolición de las murallas que circuyen la ciudad, Barcelona, 1842, citado por L. Urteaga, "El pensamiento higienista y la ciudad: la obra de P.F. Monlau (1808-1871)" en Urbanismo e historia urbana en el mundo hispánico, Universidad Complutense de Madrid, 1985, pp. 397-412; y Ganau Casas, op. cit., pp. 184-185.

${ }^{26}$ Las juntas revolucionarias que en 1840 auparon al poder al general Espartero promovieron en localidades como Granada, A Coruña y Pontevedra el comienzo simbólico en el derribo de murallas; años después, las demoliciones se reanudaron al verificarse el retorno de los progresistas al poder en el bienio 1854-1856, justificadas además por la epidemia de cólera de aquel entonces. Para un panorama de este proceso y su relación con otras transformaciones morfológicas en las ciudades españolas del siglo XIX son de obligada referencia las aportaciones de F. Quirós Linares, Las ciudades españolas a mediados del siglo XIX, Ámbito ediciones, Valladolid, 1991, pp. 57-61; "El paisaje urbano español en el siglo XIX" en Estudios sobre la historia del paisaje español, N. Ortega Cantero, ed., Los Libros de la Catarata, Madrid, 2002, pp. 155-167; y para la cuestión específica del cambio de imagen logrado con la desaparición de las murallas: M.del M. Serrano Segura, "La ciudad percibida. Murallas y ensanches desde las guías urbanas del siglo XIX", Geo Crítica, año XVI, № 91, Enero de 1991 http://www.ub.edu/geocrit/geo91.htm [Acceso: 20/03/2013].

27 Conocidas como murallas del Frente de Tierra, su arrasamiento se prolongó hasta 1880 , abriendo la posibilidad de urbanizar la calle Juana de Vega como bulevar y, sobre todo, las primeras líneas de edificaciones a través del campo del Carballo y Sánchez Bregua-Linares Rivas, que más tarde se consolidaron gracias al proyecto del primer ensanche (1883). J.R. Soraluce Blond, "La arquitectura y construcciones militares" en A Coruña: arquitectura desaparecida, F. Agrasar, ed., COAG, A Coruña, 2004, pp. 72-73.

${ }^{28}$ Un testimonio publicado en la revista Galicia en 1864, firmado por Genaro Rodríguez, certificaba el alcance de los derribos al comentar como "...el siglo XIX ha penetrado aquí con su pica, con su zapa demoledora, derruyéndolo todo y levantándose con un pueblo sobre los escombros del que allá en remotos tiempos llamaron Vico Spacorum". Tal como se reproduce en X. Garrido Rodríguez, Vigo. La ciudad que se perdió. Arquitectura desaparecida, arquitectura no realizada, Diputación Provincial de Pontevedra, 1992, p. 153; y X. Garrido Rodríguez e X.R. Iglesias Veiga, Vigo. Arquitectura urbana, Fundación Caixa Galicia-Concello de Vigo, 2000, t. I, pp. 53-55 y 173. Junto a los casos de A Coruña y Vigo, la culminación de los derribos de murallas en el período 1854 a 1868 afectó 
también a ciudades como Barcelona, Girona, Valencia, Pamplona, Tarragona, Sevilla, Córdoba, Alicante, Ciudad Real, Ciutadella...

${ }^{29}$ Ante una petición para clausurar una de sus puertas, la puerta Falsa, el Concejo había defendido en 1755 la conservación de la muralla esgrimiendo este valor de antigüedad, reiterado más tarde en un memorial de Juan de la Barrera, procurador Síndico General, fechado a 27 de septiembre de 1817 , en el que comenzaba señalando que la muralla de Lugo era "un monumento apreciable y digno de conservación por su antigüedad"; de hecho, los principales argumentos para proponer su demolición se limitaron durante décadas a su obsolescencia como elemento defensivo, hasta que en 1895 el Ayuntamiento, apoyándose en la nueva Ley de Saneamiento de Poblaciones, consultó ante la Junta de Urbanización y Obras de Madrid la posibilidad del derribo para liberar el crecimiento de la ciudad y reordenar las alineaciones en las casas próximas. A. de Abel Vilela, $A$ muralla romana de Lugo na documentación dos séculos XVI ao XX, Deputación de Lugo, 2011, pp. 79 y 123-125. También en Cataluña, en ciudades que conservaban murallas de origen romano, como Tarragona o Girona, se produjeron tempranas demandas para su conservación, con polémicas entre los defensores de su valor arqueológico y los partidarios del progreso urbano, aquí historiadores y hombres de letras frente a autoridades municipales. Ganau Casas, op. cit., pp. 188-199.

${ }^{30}$ Esta ruina y gradual desaparición vino provocada, fundamentalmente, por la propia vejez de los muros y su abandono ante la carencia de fondos municipales para asegurar su mantenimiento, como se puede comprobar a través de los documentos comentados por A. Rosende Valdés, Una historia urbana: Compostela, 1595-1780, Nigratrea, Santiago de Compostela, 2004, pp. 29-84; y L. Fernández Gasalla, “Las murallas de Santiago de Compostela (968-1875). De coraza protectora a monumento evocado", Congreso Internacional Ciudades Amuralladas Gobierno de Navarra-Institución Príncipe de Viana, 2007, pp. 1-11. Así, durante las primeras décadas del siglo
XIX, perdida toda su funcionalidad, se desembocó en el derribo de las últimas puertas, como la del Camino, la de San Roque o la Faxeira. M.P. Cores Trasmonte, El urbanismo en Santiago de Compostela en el siglo XIX, Universidad de Santiago, 1962, pp. 29-31.

31 "Las murallas ya no existen, y las puertas que se conservaban en estos últimos tiempos, han desaparecido a los golpes de reformas que embellecieron la antigua capital del Reino de Galicia, y que han arruinado los últimos restos de la arquitectura antigua que abundaba en todas partes". A. Neira de Mosquera, Monografías de Santiago y dispersos de temas compostelanos, Santiago, 1852 (Reed. Bibliófilos Gallegos, Santiago, 1950), p. 293. Citado por Fernández Gasalla, op. cit.

${ }^{32}$ A los "rudos golpes con que la han herido las últimas revoluciones, alterando profundamente su modo de ser y peculiar fisonomía" se referían años más tarde J.M. Fernández Sánchez y F. Freire Barreiro, Santiago, Jerusalen, Roma. Diario de una peregrinación..., Imp. del Boletín Eclesiástico, Santiago de Compostela, 1880, t. I, p. 6.

${ }^{33}$ Para un panorama de los principales proyectos de ensanche acometidos en la España de la segunda mitad del XIX véase M. de Solà-Morales Rubió, "Siglo XIX: ensanche y saneamiento de las ciudades" en Vivienda y urbanismo..., pp. 161-179; J.M. de Ureña Francés, J.M. Coronado Tordesillas, F.J. Rodríguez Lázaro, "De Cerdá a la ciudad descentralizada. Desarrollo, vigencia y futuro de los ensanches en España", Ingeniería y territorio, №. 88, 2009, pp. 56-61; A. Martín Ramos, El efecto Cerdà: ensanches mayores $y$ menores, Iniciativa Digital Politècnica, Barcelona, 2011. Y para el caso específico de las ciudades gallegas, J.L. Pereiro Alonso, "Os ensanches do século XIX en Galicia" en O século XIX. Galicia Terra Única, Xunta de Galicia, 1997, pp. 164-173; y J. J. González-Cebrián Tello, "Los ensanches en Galicia", Ciudad y territorio: Estudios territoriales, No 119-120, 1999, pp. 335-350.

${ }^{34}$ Dirigida a hacer frente a los problemas de demoliciones de edificios y rectificaciones de calles, tres años antes se había creado, por R.D. de 16 de junio de 1892, la Junta Consultiva de Urbanización y Obras para informar sobre todas las cuestiones de "reforma, ensanche y saneamiento de poblaciones, apertura de calles, plazas y paseos, alineaciones, rasantes....", con una actuación orientada prioritariamente hacia las capitales de provincia y grandes poblaciones españolas. Las oportunidades y ventajas especulativas aportadas por estas nuevas normativas se han destacado por Bassols Coma, op. cit., pp. 357-397; y en varias publicaciones de J. Gómez Mendoza, Urbanismo e ingeniería en el siglo XIX: Reforma interior de las ciudades y movilidad, Real Academia de Ingeniería, Madrid, 2006; "Las ciudades españolas a finales del siglo XIX: la visión de los técnicos", Ciudad y Territorio, XLIII, n 169-170, 2011, pp. 539-553.

${ }^{35}$ La proliferación de estas operaciones en España, cuando la apertura de una "Gran Vía" era sinónimo de saneamiento y riqueza para la población, tenía los precedentes de Bilbao (Gran Vía Don Diego López de Haro, 1876), o sobre todo Madrid (primer proyecto para una "gran avenida transversal este-oeste" en 1886 y definitivo en 1901), Salamanca (Gran Vía, 19021903) o Valencia (Gran Vía Marqués del Turia, 1906). I. de Solà-Morales Rubió, "Urbanismo en España: 19001950" en Vivienda y urbanismo..., pp. 183-197; y Gómez Mendoza, op. cit. En no pocas ocasiones estas intervenciones se ligaron a la basculación de los ejes de desarrollo de las ciudades por la llegada de los nuevos medios de transporte, como en Granada tras la inauguración en 1874 de la estación de ferrocarril, lo que suscitó las primeras propuestas para urbanizar una gran vía que se desarrolló fundamentalmente entre 1895 y 1903. M.A. Sorroche Guerra, "El urbanismo de Granada a finales del siglo XIX y la prensa local: el defensor de Granada" en Arquitectura y ciudad en España de 1845 a 1898, M.D. Antigüedad del Castillo-Olivares y J. R. Cirici Narváez, eds., Universidad de Cádiz, 2000, pp. 231-238.

${ }^{36}$ J.S.V., "Sección editorial. La gran mejora local", 25/6/1888, p. 1. Dado a conocer ya en J.A. Sánchez García, "Os séculos XIX e XX" en Fontes escritas para a Historia da Arquitectura e do 
Urbanismo de Galicia (séculos XIX-XX) (A. Vigo Trasancos, Coord.), Xunta de Galicia, Santiago de Compostela, 2000, Vol. II, pp. 1182-1184. Tras las siglas J.S.V. pudiera encontrarse el médico José Santaló, uno de los numerosos partidarios de Montero Ríos en la ciudad, o, con mayor probabilidad, el alcalde José Vázquez Quirós. En una memoria presentada el 6 de julio de 1885 Vázquez Quirós había condensado su negativa visión del urbanismo compostelano al afirmar que "Las calles estrechas, tortuosas y pendientes que aquí predominan, se puede decir que imprimen carácter en los habitantes", según reproduce Rodríguez González, op. cit., p. 28. La propuesta coincidió con los primeros favores que Montero Ríos deparó hacia su ciudad natal, como la creación de la Escuela de Veterinaria (1882), la Escuela de Artes y Oficios (1886), o la reforma del edificio de la Universidad que se comentará a continuación. J.A. Sánchez García, "El Patrimonio Arquitectónico. De la Reforma de Montero Ríos al Estatuto de Autonomía" en El Patrimonio Histórico de la Universidad de Santiago de Compostela. Vol. I. Estudios (M.D. Vila Jato, Coord.). Parlamento de Galicia-Universidade de Santiago, 1996, pp. 56-79; Villares Paz, "A cidade dos Dous Apóstolos (1875-1936)" en Historia da cidade de Santiago de Compostela, Consorcio de Santiago, 2003, pp. 489-491; y M. Barral Martínez, Montero Ríos e Compostela. Un feudo clientelar, Consorcio de Santiago, 2007, pp. 191-225.

${ }^{37}$ Entendemos aquí por haussmanización, siguiendo a Benevolo, la apertura de nuevas calles cortando un trazado preexistente, normalmente para erradicar la intrincada red viaria y densificación habituales en las ciudades preindustriales. L. Benevolo, Diseño de la ciudad. 5. El arte y la ciudad contemporánea, GG, Barcelona, 1982, pp. 55-70; R. Segre, Historia de la arquitectura y del urbanismo. Paises desarrollados. Siglos XIX y XX, IEAL, Madrid, 1985, pp. 62-68; B. Gravagnuolo, Historia del Urbanismo en Europa, 1750-1960, Akal, Madrid, 1998, pp. 37-50; y M. Roncayolo, "Le modèle haussmannien" in Histoire de la France urbaine, G. Duby, coord. Tomo IV, La ville de l'âge industriel, Editions du Seuil,
Paris, 1983, pp. 78-117. En Santiago de Compostela las estrategias de reforma interior características de la ciudad burguesa sólo habían promovido, desde 1869, la aplicación de diferentes planes de alineaciones como los aprobados para las calles Calderería y Preguntoiro (1870), Mazarelos (1870), rúa do Vilar (1871), rúa do Castro y callejón de Altamira (1872), rúa da Troia (1876), plazuela de san Agustín y Pescadería Vella (1877), rúa Nova (1878), Vía Sacra (1879), Casas Reais (1881), travesía de san Paio (1885), plaza de Cervantes (1886), o calle Raíña (1888), por destacar algunas de las principales vías del casco viejo según la documentación conservada en el fondo municipal del Arquivo Histórico da Universidade de Santiago de Compostela.

${ }^{38}$ Décadas atrás el escritor romántico Antonio Neira de Mosquera había percibido el potencial de las primeras intervenciones del urbanismo moderno para cambiar esa fisonomía antigua: "Este es el Santiago de nuestros días, y gracias a las continuas mejoras que recibe, entre las que merece particular distinción, la hermosa y despejada alameda, llegará muy pronto a desterrar de una vez, la fisonomía antigua que tenía en muchas calles y edificios". Neira de Mosquera, op. cit., p. 296. En la misma línea, el arquitecto municipal Manuel de Prado y Vallo confesaba en 1860 su disgusto ante el trazado viario de la vieja Compostela, que ya proponía mejorar con la apertura de una calle desde Santa Clara hacia el Hórreo, enlace hacia la futura estación de tren; o la corporación municipal de 1881 al soñar con abrir una calle acristalada que, mediante expropiaciones y derribos, comunicara la plaza de Mazarelos con la rúa do Franco y el Pombal. Rodríguez González, op. cit., p. 27; y Rosende Valdés, Compostela 1780-1907: una aproximación a la ciudad decimonónica, Consorcio de Santiago-Teófilo, 2014, pp. 376-377.

${ }^{39}$ La propuesta de ensanche y reforma interior de la calle Calderería se aprobó en la sesión municipal del 24 de febrero de 1887, a instancias del alcalde José Vázquez Quirós. En lugar de abordar todo el conjunto de expropiaciones se decidió posponer el derribo de las casas situadas frente al edificio de la Universidad hasta que viniera a Santiago el arquitecto nombrado por el Ministerio de Fomento para proyectar sus obras, y así consultarle la solución más conveniente en relación con el ensanche de la vía; de este modo, en 1887 sólo se acordó derribar las casas del primer tramo que iría desde Calderería hasta la plazuela de la Fuente Seca, números 1 al 23, incluidas las casas de la calle del Castro 8 al 22, iniciándose los primeros trámites para las expropiaciones. AHUS. Fondo Municipal. Expropiaciones y derribos, 18871891. "Exp. de expropiación de las casas comprendidas en el 1er trozo de la calle de la Calderería y las posteriores de la del Castro, año de 1887".

${ }^{40} \mathrm{El}$ proyecto no fue aprobado hasta el año 1893, prolongándose sus obras en el tiempo bastante más de lo previsto, al desarrollarse entre 1894 a 1906. Sánchez García, op. cit.; X. Fernández Fernández, Arquitectura del eclecticismo en Galicia (1875-1914). Vol. II. Edificación del ferrocarril, escolar y de recreo, Universidade da Coruña, 1996, pp. 119-130; y Barral Martínez, op. cit., pp. 193-206.

${ }^{41}$ En relación con este punto de inicio para la "gran vía", ya años atrás, desde 1864 a 1871, el arquitecto municipal Manuel de Prado y Vallo había redactado los primeros proyectos para el desarrollo de la futura calle del Hórreo, potenciada como eje de expansión a partir de la construcción de la estación de Ferrocarril de Cornes (1873). A comienzos de la década de los ochenta el nuevo arquitecto municipal, Faustino Domínguez Coumes-Gay proyectó la modificación definitiva del encuentro de esta calle del Hórreo con la Porta da Mámoa, con lo que se abría el camino para la urbanización y consolidación de este importante eje, reforzado gracias a la construcción de la Escuela de Veterinaria (1903-1913), otra obra debida a la influencia de Montero Ríos. Sobre estas incipientes dinámicas de expansión urbana véase P. Costa Buján, J. Morenas Aydillo, Santiago de Compostela, 1850-1950. Desenvolvemento urbano. Outra arquitectura, COAG, Santiago de Compostela, 1989, pp. 46-48.

${ }^{42} \mathrm{El}$ problema de los incómodos accesos al mercado se mantuvo tras abandonarse el proyecto de "gran vía", 
suscitando ya en enero de 1906 otra radical propuesta de cirugía urbana que implicaría el desmontaje y traslado de la iglesia de San Benito do Campo y el arrasamiento del ruinoso convento de San Agustín, para así abrir una amplia calle paralela a Virxe da Cerca, más cómoda para el movimiento de carros y la salida de la ciudad en las direcciones de A Coruña y Lugo. La propuesta, relacionada con la alineación del Cantón de san Bieito en marcha desde el año anterior, fue defendida por el alcalde Lino Torres, según la documentación que reproduce M.P. Casas Gil, La transformación urbana de un centro histórico. Santiago de Compostela, 1886-1908 (plaza de Cervantes, calle del Preguntoiro, Azabachería, Casas Reales, Algalia de Arriba y Algalia de Abajo), Tesina de Licenciatura, Universidad de Santiago de Compostela, 2004, p. 47.

${ }^{43} \mathrm{El}$ arquitecto municipal sólo bosquejó un anteproyecto, sin memoria ni presupuesto, pero suficiente para desatar las reacciones contrarias de los vecinos de la calle Calderería, plaza de la Universidad y plaza del Instituto más directamente afectados por las posibles demoliciones. AHUS. Fondo Municipal. Expropiaciones y derribos, 1887-1891. "Exp. de expropiación de las casas comprendidas en el $2^{\circ}$ trozo o manzana de la calle de la Calderería que da frente a la Universidad, año de 1891 ". Otros vecinos, aun reconociendo lo poco conveniente que sería alterar el ambiente de la ciudad y "quitarle por completo el aspecto severo y grave que ostenta y que tan bien se ajusta a la grandiosidad de sus monumentos", eran favorables a llevar adelante las demoliciones, como consta en el escrito presentado a 21 de octubre, firmado por los señores Santiago de Andrés Moreno, José Harguindey, Valeriano Pastrana, Miguel Gómez y Vicente Taboada. Tras aprobarse la propuesta en la sesión municipal del 26 octubre de 1891, la reclamación posterior de otro grupo más numeroso de vecinos pidió mantener la alineación fijada en 1870 por Prado y Vallo, alegando que "la constitución peculiar de Santiago, edificado en un monte, no permite esas amplias y hermosas calles modernas", y que "el ensanche aquí es antitético al ensanche de otros pueblos" ya que no se dirigía hacia las afueras sino que se desarrollaba en pleno casco histórico. Estas alegaciones, contenidas en varios impresos dirigidos al Ayuntamiento desde diciembre de 1891, se renovaron en 1896 ante otro intento municipal, hasta conseguir el definitivo abandono de la idea el 23 en marzo de 1900, tal como se expone también por Casas Gil, op. cit., p. 45; y Rosende Valdés, Compostela 1780-1907..., pp. 162-164.

${ }^{44}$ Elaboradas por el arquitecto municipal Miguel Ferro Caaveiro y corregidas por Ventura Rodríguez, durante el siglo XIX fueron completadas con diferentes bandos y reglamentos de policía urbana, de manera que siguieron en vigor hasta las nuevas ordenanzas aprobadas en 1907; estas fueron redactadas con el asesoramiento de los técnicos Manuel Hernández y ÁlvarezReyero y Manuel Pereiro Caeiro, más el archivero e historiador Pablo Pérez Costanti. Sobre la repercusión de las sucesivas ordenanzas y bandos a lo largo de los siglos XVIII y XIX véanse: $F$. Singul Lorenzo, La Ciudad de las Luces. Arquitectura y urbanismo en Santiago de Compostela durante la Ilustración, Consorcio de Santiago, 2001, pp. 103112; J. Morenas Aydillo, "La ciudad reconstruida en el XIX" en Santiago de Compostela. La ciudad histórica como presente, C. Martí Arís, coord., Santiago de Compostela, 1995, pp. 108-122; y, el más reciente trabajo de Rosende Valdés, Compostela 1780-1907..., pp. 53-72. En cuanto a la situación anterior a 1780 , con el precedente de algunas disposiciones de los siglos XVI y XVII orientadas a evitar estorbos e inconvenientes de la estrechez viaria o de los típicos voladizos del caserío de tradición medieval: Rosende Valdés, Una historia urbana..., pp. 132-139.

${ }^{45}$ De hecho, ya en 1856 se había planteado una idea similar, aprovechando la circunstancia de que dos viejas casas que se encontraban en el lateral oeste de la plaza del Toral se hallaban en ruinas; estas casas fueron finalmente derribadas, pero para levantar sobre su solar y adyacentes el académico inmueble diseñado por Prado y Vallo que todavía hoy se conserva allí, como frente de toda la manzana objeto de la propuesta lanzada en el año 1900. Costa Buján y Morenas Aydillo, op.cit., pp. 102-103; Casas Gil, op. cit., p. 46; y Rosende Valdés, Compostela 1780-1907..., pp. 156-158.

${ }^{46}$ En los comentarios de la prensa de aquellos días se llegó a proponer bautizar la futura vía como "avenida Montero Ríos". Barral Martínez, op. cit., p. 339. En esta ocasión la iniciativa compostelana podría relacionarse también con el eco de las obras de la barcelonesa vía Laietana, cuyos primeros derribos se habían iniciado en 1908 para enlazar el ensanche con la zona portuaria, de nuevo perforando un sector del casco antiguo. Ganau Casas, op. cit., pp. 430-437.

47 "... regularizadas las líneas, puede cubrirse al resto con césped y hacer praderas de estilo inglés, en cuya ornamentación entre también algún arbusto". Pese a la sensibilidad de este concejal al reconocer el "sello característico de época" de la vieja Compostela, lo cierto es que un derribo y urbanización de esta envergadura serían difícilmente conciliables con el arranque de algunas de las rúas más típicas del casco viejo. Volviendo a vincular esta intervención en la plaza del Toral con el proyectado ensanche, en la misma moción se pedía dar inicio a las obras de urbanización de los terrenos de Agros de Carreira, todo ello justificado para proporcionar trabajo a los obreros en unos momentos de crisis económica y conflictividad social. AHUS. Fondo Municipal. Libros de actas municipales. Año 1919, sesión del 17 de diciembre, fols. 115-116. A esta propuesta $\sin$ fruto se ha referido también Rosende Valdés, Compostela 1780-1907..., pp. 158-159.

${ }^{48} \mathrm{El}$ artículo formaba parte de una serie sobre mejoras locales, incluyendo aspectos estéticos para la conservación de la ciudad histórica, ya que el anónimo autor se posicionaba contra el uso del cemento en el pavimentado de calles, optando por mantener los empedrados tradicionales. Este trasfondo de crítica a los nuevos materiales, citando las "obras de cementación" que estaban desnaturalizando la "fisonomía histórica y artística de esta urbe museo", ya había dado lugar en abril de 1917 a un intenso debate municipal sobre la propuesta de usar cemento y asfalto para el pavimentado de la rúa do Vilar, finalmente desechada. AHUS. 
Fondo Municipal. Libros de actas municipales. Año 1917, sesiones del 4 y 11 de abril, fols.53 y 55-58; citado también por Villares Paz, op. cit., pp. 486-487. La agresión al "aspecto artístico" de la población, denunciada entonces por algunos concejales sensibles ante un patrimonio ya considerado como vital para el desarrollo turístico, se completó en 1930 con la mención al añejo color local de Santiago, abogando también por mantener las calles con su tortuosidad y pendientes, todo ello propio del "matiz vetusto y arqueológico de Compostela". "Intereses comunales. Aspectos de la vida municipal (noveno y último)", El Compostelano, 16/04/1930, p. 1. También se ha referido a este artículo, destacando la contraposición cemento-piedra en el contexto de maduración de las opciones de arquitectura regionalista, con la coincidencia de que en Santiago se estaban acometiendo las obras del Hotel Compostela, uno de los edificios emblemáticos de esta corriente, J.R. Iglesias Veiga, La tendencia regionalista en la arquitectura gallega de las primeras décadas del siglo XX, Tesis Doctoral, Uned, 2010, p. 100.

49 M. Prieto Camiña, "Crónicas regionales. La destrucción de lo típiCo", Eco de Galicia, año XIV, n 355, 01/01/1930, pp. 22-23. Algunos años antes en Betanzos, otro pueblo que conservaba como Combarro un pintoresco conjunto de hórreos, en este caso los hórreos palafíticos situados en la zona de A Galera, junto al río Mendo, fue el fotógrafo local José Veiga Roel quien denunció varios atentados al patrimonio como la destrucción de las capillas de la Orden Tercera y Vera Cruz anexas a la iglesia de San Francisco, el proyecto para derribar la Porta das Doncelas, o los equivocados blanqueamientos de muros antiguos; en su defensa de la conservación estética del conjunto citaba una conferencia del escritor Juan Armada y Losada, marqués de Figueroa, postulando en 1920 que sólo los artistas debían tener intervención sobre una ciudad histórica. J. Veiga Roel, "A porta das Doncelas", Rexurdimento, ${ }^{\circ}$ 4, 16 septiembre 1922, reproducido en $X$. Torres Regueiro, "Os animadores da prensa local" II, Anuario Brigantino, $\mathrm{n}^{\circ}$ 11, 1988, pp. 69-124.
50 Sobre la recepción de estos autores en España es necesario precisar que si bien las ideas de Buls tuvieron un eco casi inmediato, coincidiendo con la segunda edición de su obra en 1894, las de Sitte sólo comenzaron a divulgarse a partir de la edición francesa aparecida en 1902, como se ha certificado para Cataluña, y sobre todo desde la primera edición en castellano de 1926. G. R. Collins y C. Collins, Camillo Sitte y el nacimiento del urbanismo moderno, GG, Barcelona, 1980, p. 75; y Ganau Casas, op. cit., pp. 420-423.

${ }^{51}$ Las consideraciones de Giovannoni nacieron desde la crítica a los percements haussmanianos por la primacía de la especulación sobre el interés público. Giovannoni fue, de hecho, el primero en identificar y valorar el "patrimonio urbano", en los textos "Vecchie città ed edilizia nuova" (1913) e "Il 'diradamento' edilizio dei vecchi centri: il quartiere della Rinascenza in Roma" (1913), tal como se contextualizan y analizan en Choay, op. cit., pp. 175180. Sobre la relevancia de los escritos e intervenciones de Giovannoni véase también P. Sica, Storia dell'urbanistica. III. II Novecento, Editori Laterza, Bari, 1980, p. 62; M. De Benedetti e A. Pracchi, a cura di, Antologia dell'architettura moderna: testi, manifesti, utopie, Zanichelli, Bologna, 1988, pp. 137-154; y J. Jokilehto, A history of architectural conservation, Butterworth-Heinemann, Oxford, 1999, pp. 219-222.

${ }^{52}$ Esta nueva percepción del urbanismo, visto ya como símbolo de civilización, fue relacionada por Isac con hitos europeos como la celebración del I Congrès International d'Art Public de Bruselas, que ya en 1898, siguiendo ideas de Ruskin y Sitte, había acogido las primeras críticas contra los excesos de regularidad geométrica en los ensanches y aperturas de nuevas calles. Isac, op. cit., pp. 96-104.

${ }^{53}$ Debe destacarse que, entre los monumentos histórico-artísticos declarados en el decreto del 3 de junio de 1931 antes aludido, según la lista elaborada por Gómez Moreno, Elías Tormo, García Bellido, Sánchez Cantón y Torres Balbás, se incluyeran viviendas como la casa de los Golfines y una casa morisca en Cáceres, la casa de los Caballeros de Santiago en Córdoba, la casa de las Cadenas de Úbeda, la casa árabe en la calle del Gigante de Ronda, la casa de la Salina en Salamanca, la casa de las Tornerías, el corral de Don Diego y el taller del Moro en Toledo, la casa del Cid en Zamora, o la casa de la Maestranza en Zaragoza. Decreto del Ministerio de Instrucción Pública y Bellas Artes del 3 de junio de 1931, Gaceta de Madrid, n 155, 4 junio de 1931.

54 La ciudad distraída, ensimismada en su papel rector para la religión y la ciencia, son los gráficos calificativos que, apoyados en textos de la época, emplea Ramón Villares para caracterizar la etapa de la Restauración hasta la Guerra Civil. Con acierto este mismo autor plantea que tal declive no fue obstáculo para la remodelación del casco histórico y sobre todo la incorporación de nuevos edificios singulares, ahora de tipo civil, que redondearon la dinámica de monumentalización iniciada en la época Moderna. R. Villares Paz, op. cit., pp. 465-491.

${ }^{55}$ Sobre el panorama urbanístico y arquitectónico de las ciudades gallegas en torno a 1909, incidiendo precisamente en la recepción de estas tendencias foráneas y los nuevos marchamos de lujo y magnificencia exhibidos por las construcciones privadas y oficiales se ha ocupado A. Vigo Trasancos, "Galicia no horizonte de 1909. Cidades e arquitecturas para unha época de esplendor burgués" en Exposición Galega de 1909. Conmemoración do $1^{\circ}$ Centenario Exposición Regional Gallega Santiago 1909 (C. García Martínez y R. Méndez García, eds.), Consorcio de Santiago, 2010, pp. 31-78.

${ }^{56}$ En su repaso a la evolución urbanística de las ciudades españolas Bonet contrapuso el inmovilista panorama social y urbano con los pretenciosos alzados de edificios derivados de la prosperidad económica en los años del cambio de siglo. Bonet Correa, op. cit., p. 25-26.

57 Esta expansión del credo clasicista y la imposición de sus nuevas normas de decoro arquitectónico frente a las caprichosas y heterodoxas formas barrocas sirve como colofón a la reciente monografía de A. Vigo Trasancos, Barroco. La arquitectura sagrada del 
antiguo Reino de Galicia, Consorcio de Santiago-Teófilo edicións, 2012, pp. 122-129.

58 Véase el comentario más pormenorizado de estos proyectos en Costa Buján y Morenas Aydillo, op. cit., pp. 92-107; J.A. Sánchez García, La arquitectura teatral en Santiago de Compostela (1768-1946), Ediciós do Castro, Sada-A Coruña, 1993, pp. 86-95; y Rosende Valdés, Compostela 1780-1907..., pp. 199-212 y 187-192.

59 Según las pautas difundidas desde un ámbito parisino que por entonces era referencia cultural para toda Europa, y especialmente España, en el que destacaba la aportación del influyente tratadista y teórico César Daly. M. Eleb et A. Desbarre, Architectures de la vie privée. XVIIe-XIXe siècles, Hazan, Paris, pp. 87-110 y 261-281.

${ }^{60}$ Gracias al Decreto aprobado el 8 de enero de 1870 los maestros de obras obtuvieron la equiparación con los arquitectos para proyectar y dirigir todo tipo de casas y construcciones particulares, lo que validó tanto a aquellos que ya venían ejerciendo desde las primeras décadas del siglo como a los formados más recientemente en las Escuelas Provinciales de Bellas Artes, desde la reorganización de 1849, y en la propia Escuela Especial de Arquitectura de Madrid desde 1852. Para el panorama de su formación y actividad en Galicia, con figuras como Jenaro de la Fuente Domínguez en Vigo, Alejandro Rodríguez Sesmero en Pontevedra, Gabriel Vitini Alonso en A Coruña o Manuel Riva de Soto en Ferrol, véase J.A. Sánchez García, "Maestros de obras y aparejadores en la época contemporánea" en El aparejador y su profesión en Galicia. De los maestros de obras a los arquitectos técnicos (J.A. Sánchez García y J.M. Yáñez Rodríguez, eds.), Consello Galego de Aparelladores e Arquitectos Técnicos, Santiago de Compostela, 2001, pp. 146-215.

61 La aportación de estos dos maestros de obras a la renovación de la arquitectura compostelana durante el eclecticismo, en el contexto de las operaciones de reforma interior y el nuevo énfasis en la ornamentación ya comentados, fue señalada también por Costa Buján y Morenas Aydillo, Santiago de
Compostela..., pp. 92 y 395; y J.M. López Vázquez, "Arte Contemporáneo" en Galicia. Arte, Hércules de ediciones, A Coruña, 1993, t. XV, pp. 139-148.

$62 \mathrm{El}$ nuevo inmueble ocasionó la destrucción de una casa vinculada a los condes de Altamira, una valiosa muestra de arquitectura gótica, como lamentó algún erudito local: B. Barreiro de V.V., "Las Casas do Campo. Solar de los condes de Altamira", Galicia Diplomática, $\mathrm{n}^{\circ}$ 20, 19 de mayo de 1889, pp. 153-154. Junto a su escala, los miradores acristalados y balcones de esta avasalladora construcción demostraron las nuevas posibilidades de la fundición artística, con lo que se incorporaba otra novedad, en este caso industrial, para el distanciamiento con los elementos y materiales tradicionales en las viviendas del casco viejo compostelano. Con razón Otero Pedrayo valoró sus soportales como "muy poco compostelanos", lo que podría extenderse a las líneas maestras de toda la construcción. R. Otero Pedrayo, Guía de Galicia, Galaxia, Vigo, 1954, p. 387. Sobre la trayectoria y producción de Pereiro Caeiro es de obligada consulta el estudio monográfico de J. L. Pereiro Alonso, Rincones de Compostela. La obra de Manuel Pereiro Caeiro, Consorcio de Santiago-Ronsel, Santiago de Compostela, 1996.

${ }^{63}$ En Santiago de Compostela los Almacenes Simeón, sede de una casa comercial dedicada a los textiles, se asentaron en otro gran inmueble situado en Casas Reais n 3-5, proyectado en 1919 por Jesús López de Rego con un lenguaje clasicista pero no exento de puntos de contacto con la Secession vienesa. AHUS. Fondo municipal. Licencias de obras, año 1919, Sig. 598, fols. 154-164. Años antes se había presentado en Vigo el proyecto para el establecimiento comercial de Pedro Román y nueva sede del Casino, en la calle Joaquín Yáñez (Jenaro de la Fuente Domínguez, 1889), con una amplitud de vanos hasta entonces inhabitual en la ciudad; en A Coruña fue en 1900 cuando el proyecto para la tienda de modas Villa de París (Florián Calvo), marcó otro hito local con su fachada de fundición de hierro que obviaba todas las prescripciones de las ordenanzas vigentes en cuanto al uso de la piedra como material constructivo. Garrido
Rodríguez e Iglesias Veiga, op. cit., t. I, pp. 252-255; J.A. Sánchez García, “Los primeros cines" en Cines de Galicia, J.L. Cabo y J.A. Sánchez, eds., Fundación Barrié, A Coruña, 2012, p. 64.

${ }^{64}$ Con precedentes como las nuevas manzanas de viviendas levantadas frente al mercado de abastos (18701873), fruto de la ocupación del solar del antiguo palacio de Altamira, o el banco de Olimpio Pérez ya señalado, las nuevas pautas de monumentalidad provocaron rupturas como la que introdujo en la línea de soportales de la rúa do Vilar la vivienda proyectada en dos fases por Manuel Felipe Quintana y Manuel Hernández y Álvarez-Reyero para los números 28 a 32, propiedad de Antonio Ínsua Rey (1897-1899); pese a su notable cambio de escala, el arquitecto municipal Álvarez Reyero consideró este proyecto "ajustado a las buenas prácticas de construcción y ornato". AHUS. Fondo municipal. Licencias de obras, año 1897, C-577, fols. 183 y ss. Ambicioso inmueble también destacado por Rosende Valdés, Compostela 1780-1907..., pp. 278-285. En cuanto a los bajos comerciales, el creciente protagonismo de los escaparates se aprecia en los números 23 de Casas Reales (M. Pereiro Caeiro, 1881), 4 de Huérfanas (J. de la Fuente Domínguez, 1900), 2-4 del Preguntoiro (M. Pereiro Caeiro, 1902), 10 de Huérfanas ( $M$. Pereiro Caeiro, 1903), aquí con una doble altura en las arcadas que cobijan la entrada, o el 45 de Calderería (M. Pereiro Caeiro, 1904), ya incorporando la secuencia de bajo con entresuelo conforme a los cánones habituales en los establecimientos de comienzos de siglo. Sobre las implicaciones estéticas del desarrollo de escaparates y entresuelos comerciales, un revelador análisis contemporáneo se publicó por B. Pite, "Street Architecture", Journal of the Society of Arts, n. 50, 25/04/1902, pp. 505-515.

${ }^{65}$ Este gran edificio, proyectado en el verano de 1921, o el aprobado en junio de 1922 para la avenida Linares Rivas $n^{\circ} 35-40$, conocido como Casa Barrié (Leoncio Bescansa y Antonio Tenreiro, 1926), fueron considerados los primeros "rascacielos" de la ciudad. La posibilidad de alcanzar los $35 \mathrm{~m}$ como nuevo tope de altura ha- 
bía quedado abierta en España desde 1918, por una modificación legal sobre la Ley de Saneamiento de Poblaciones de 1895, orientada a favorecer la rentabilidad del segundo tramo de la Gran Vía madrileña, enseguida extendida al resto del país, como en su momento señaló J.R. Alonso Pereira, "El proyecto de un Banco" en El Banco Pastor de La Coruña, VV.AA.,La Coruña, 1994, pp. 175-176. Amigo del coruñés Antonio Tenreiro, Leopoldo Torres Balbás no dudó en elogiar el proyecto para el Banco Pastor, si bien reconociendo que este y otros ejemplos de los "modestos rascacielos españoles" estaban surgiendo por el deseo de imitar a las ciudades norteamericanas, no tanto por necesidad real como por afán de "lujo, esnobismo o reclamo comercial", con la citada ruptura de un perfil urbano hasta entonces presidido por "las flechas y agujas de los templos, únicos y agudos hitos hasta ahora dominadores de la ciudad pintoresca de tejados y buhardillas". T., "Los modestos rascacielos españoles", Arquitectura, n 37, 1919, pp. 210-219; reproducido por Alonso Pereira, op. cit., pp. 168-169.

${ }_{66}^{6}$ De forma similar a lo ocurrido en el París de Haussmann, la conciencia conservacionista, que Sutcliffe definió como batalla por la preservación, nació como una reacción tardía ante la irreversible desaparición de trazados o, como en este caso, fragmentos de la vieja ciudad. A. Sutcliffe, Ocaso y fracaso del centro de París, GG, Barcelona, 1973, pp. 187-215.

${ }^{67}$ Pese a que por algún tiempo se creyó que esta estancia se había prolongado hasta 1874, en realidad Emilia sólo se trasladó a Santiago desde el año 1869 para pasar algunas cortas temporadas, según la reciente investigación de J.M. González Herrán, "Antonio Casares Rodríguez y Emilia Pardo Bazán", Boletín das Ciencias, n 75, outubro 2012, pp. 177-187.

68 Emilia Pardo Bazán, "La vida contemporánea", LIA, 30/08/1909, n 1444, p. 570. Esta visión crítica sobre las irrupciones de la vida moderna en el ambiente señorial de una vieja ciudad podría relacionarse con un posicionamiento similar de Miguel de Unamuno, suscitado tres años antes, con motivo de la apertura de la Gran Vía de Sala- manca y los paralelos derribos y alineaciones que estaban haciendo peligrar el "carácter pintoresco" de aquella capital, interpretada ya como "ciudad museo" pero amenazada por el mal gusto de la construcción moderna: "Conferencia del Sr. Unamuno. Salamanca artística", El Lábaro, 21/03/1906, según la referencia aportada por J.I. Díez Elcuaz, Arquitectura y urbanismo en Salamanca (1890-1939), Colegio Oficial de Arquitectos de León, 2003, p. 46 y $52-53$

${ }^{69}$ Las críticas a sus formas aparentemente novedosas pero pronto percibidas como de corta vida, como una arquitectura frívola, sin sentido ni racionalidad, rompiendo leyes de simetría y trastocando la estética tradicional, se repiten en distintos testimonios peyorativos de época comentados en M. Freixa, El modernismo en España, Cátedra, Madrid, 1986, 22-24 y 41-52; y más recientemente en los textos que inciden en su superficialidad adornista y cosmopolitismo enfrentado a las corrientes vernáculas en $\mathrm{O}$. da Rocha Aranda, El modernismo en la arquitectura madrileña. Génesis y desarrollo de una opción ecléctica, CSIC, Madrid 2009, pp. 69-103.

70 Sobre las particularidades de esta curiosa construcción, a medio camino entre el palacete y la villa suburbana, véanse J. Bérchez Gómez, "Hierro y modernismo en la arquitectura de Salamanca", Estudios Pro Arte, n 7-8, julio-diciembre 1976, pp. 24-47; J. Arrechea Miguel, "Arquitectura" en Historia del Arte de Castilla y León. Tomo VIII. Arte Contemporáneo, Ámbito eds., Valladolid, 1994, pp. 24-26; y Díez Elcuaz, op. cit., pp. 146-149. El estudio de Díez Elcuaz confirma además que, coincidiendo con la conclusión de la casa Lis, en Salamanca se alcanzó el apogeo en cuanto al enriquecimiento decorativo en las edificaciones privadas de inspiración modernista, quizás por un no desdeñable proceso de emulación.

71 E. Pardo Bazán, "La vida contemporánea", LIA, 31 de julio de 1916, n 1805, p. 490; y "Exposición de arte gallego. La conferencia de la condesa de Pardo Bazán", LVG, 29/08/1917, pp. 1-2. En la prensa local el suceso fue recogido en El Castellano, 04/03/1905, p. 1. Es importante anotar que Emilia estuvo en Salamanca durante la Semana Santa de aquel mismo año 1905, participando en una velada en memoria del finado poeta José María Gabriel y Galán, por lo que pudo conocer de primera mano aquella polémica. E. Acosta, Emilia Pardo Bazán. La luz en la batalla. Biografía, Lumen, Barcelona, 2007, p. 474.

72 Debemos estas informaciones, inéditas, a la amabilidad de José Ignacio Díez Elcuaz, quien las recogió entre los datos que le permitieron elaborar su tesis doctoral sobre la arquitectura y el urbanismo de Salamanca en el período 1890-1939 ya referenciada.

73 Años más tarde el arquitecto gallego Antonio Palacios visitó la capital salmantina y dejó constancia de su opinión sobre la necesidad de evitar edificaciones discordantes, como esta casa de la calle Zamora o un ventanal modernista en el palacio de los Maldonado de Amatos, este último añadido al reformarse como sede del Casino. Un artículo local recoge su estancia y discurso de apertura en la Escuela de Bellas Artes de San Eloy, reclamando preservar aquellos valores artísticos que pudieran servir para estimular el turismo. Al enjuiciar el patrimonio de la vieja Salamanca, Palacios habría comentado: "En Salamanca, menos que en ninguna otra ciudad, deberían los municipios tolerar se edificara sin tener en cuenta, siempre, los buenos modelos del pasado que aquí existen"; en caso de recibir algún encargo para esta ciudad, Palacios adelantaba que pondría todo su empeño en imitar a los maestros del Renacimiento español. Andrés P. Cardenal, "Así debiera ser Salamanca", Boletín de la Cámara Oficial de Comercio e Industria de Salamanca, n²9, octubre de 1916, pp. 1-3.

74 Las Ordenanzas municipales de Santiago redactadas entre 1905 y 1907, que comenzaron a aplicarse desde el 1 de enero de 1908, obviaban estas preocupaciones. Pese a que incluían dos artículos sobre las edificaciones en el futuro ensanche (arts. 75 y 76), no había normas específicas sobre el ambiente o elementos típicos del casco viejo, limitándose a disponer que los elementos de ornato de las fachadas debían atenerse a las reglas del buen 
gusto, sin pintarlas de "colores demasiado vivos que hieran la vista", y por supuesto que las obras de nueva planta debían ajustarse a los planos vigentes de alineaciones y rasantes. Ordenanzas municipales de Santiago de Compostela, Escuela Tip. Municipal, Santiago, 1907, arts. 77, 78, 35 y 19.5.

${ }^{75}$ Este reconocimiento partió de escritos como los de Jeroni Martorell y Ramón Rucabado citados por Ganau Casas, op. cit., pp. 438-440; y del mismo "Reinventing memories: the origin and development of Barcelona's Barri Gòtic", 1880-1950", Journal of Urban History, vol 34, núm. 5, 2006, pp. 795-832. Años más tarde, en 1916 surgió otra propuesta complementaria para poner en valor el barrio barroco de la Virreina, ahora con origen en un estudio realizado en la Escuela de Arquitectura por Antoni Puig i Gairalt y Lluis Bonet i Garí, de nuevo en el contexto de nuevos derribos, en este caso los necesarios para iniciar la frustrada vía C que atravesaría la zona del Raval consolidada desde el siglo XVIII. Ganau Casas, op. cit., pp. 460-461.

${ }^{76}$ Publicado en "Apuntes de viaje. Una ciudad gótica. Nuremberg", El Imparcial, 14/10/1889, pp. 5-6; y recogido posteriormente en E. Pardo Bazán, "Una ciudad gótica. Nuremberg" en Por Francia y por Alemania (crónicas de la exposición) (1890). Sobre los intensos viajes de Emilia, y su repercusión literaria, se ha ocupado J.M. González Herrán, "Andanzas e visións de dona Emilia (a literatura de viaxes de Pardo Bazán)", Revista Galega do Ensino, № 27, Maio 2000, pp. 37-62. Como muestra del impacto de este texto cabe citar un artículo de opinión del crítico de arte F. Miquel Badía, donde reproducía el párrafo en el que Emilia se burlaba de la monótona concepción del ornato público en las ciudades españolas, con una estética "semejante a una cárcel modelo: celdas a derecha e izquierda, numeradas y pintadas de gris". F. Miquel y Badía, "La monotonía en las ciudades", El Liberal, 14/04/1890, pp. 1 y 2; cuatro años más tarde este mismo F. Miquel reseñó elogiosamente la obra de Charles Buls L'esthétique des villes en tres artículos publicados en el Diario de Barcelona que comenta Ganau Casas, op. cit., p. 421.
77 "De mi tierra. El "mediado" en Betanzos", El Imparcial, 24/07/1893, p. 3. Recogido más tarde en E. Pardo Bazán, Por la España pintoresca (1896). A este artículo, elogiando su estilo y ricas apreciaciones sobre el paisaje humano y arquitectónico de la ciudad de Betanzos, se ha referido también C. Patiño Eirín, "Un artículo costumbrista sobre Betanzos, de Emilia Pardo Bazán", Anuario Brigantino, $\mathrm{n}^{\circ} 15,1992$, pp. 273-278.

${ }^{78}$ La particular sensibilidad de este autor hacia la conservación del patrimonio gallego se detecta en poemas como "O mosteiro de San Esteban de Ribas de Sil", publicado originalmente en el poemario Falenas (1903), "O Pazo", dedicado a los señores del pazo orensano de Vilaseco, en Nido de áspides (1908), o en el capítulo "La Turena", en el libro de viaje Remansos de paz: campos de guerra (1915), al evocar las desaprovechadas posibilidades de Galicia para el turismo, lamentando el olvido y abandono de castillos, pazos y monasterios. Discípulo y amigo del historiador Marcelo Macías, la actividad de éste en la Comisión Provincial de Monumentos de Ourense, donde había fundado su Boletín, podría relacionarse con algunas de las preocupaciones conservacionistas de Antonio Rey Soto.

79 A. Rey Soto, "Los soportales de Santiago", Diario de Galicia, $11 / 08 / 1922$, p. 1. Reproducido también en otros diarios gallegos, como Galicia. Diario de Vigo, 12/08/1922, p. 2 -objeto de comentario por Iglesias Veiga, op. cit., p. 186-, y publicado póstumamente en Obras completas. Vol IV. Período hispanoamericano. Obras en prosa, Revista Estudios, Madrid, 1964, pp. 104-105. Rey Soto disponía en su biblioteca de buen número de obras de Emilia Pardo Bazán, pero también, y esto podría ser más significativo para su interés por la conservación del patrimonio arquitectónico, de los principales estudios de Vicente Lampérez, como el antes aludido sobre Las ciudades españolas y su arquitectura municipal...; los volúmenes de su biblioteca, donados al monasterio de Poio, permiten aseverar estas lecturas, a falta de una catalogación completa de este ingente fondo.
80 Siendo alcalde Vicente Goyanes Cedrón, los días 8 y 9 de agosto se discutió ampliamente en el consistorio local sobre la decisión a adoptar con respecto a una solicitud de obras en la fachada interior bajo el soportal de la vivienda número 59 de la rúa do Vilar. Algunos concejales, y el mismo arquitecto municipal Mariano Fernández Ragel, opinaban que tales obras, ya que el edificio se conservaba en buen estado, no podían ser motivo para obligar al propietario a derribar el soportal y retrasarse a la alineación fijada para la calle en 1871. Sin embargo, en la votación final se impuso la opción apoyada por la Comisión de Fomento, basada en la interpretación más literal del artículo 46 de las Ordenanzas municipales sobre mejoras de aspecto en fachadas fuera de línea, y en el precedente de recientes derribos en la misma acera de los números impares, acordados en 1917 hasta el número 67, con lo que se consumó la desaparición del último soportal que quedaba en aquella manzana de la céntrica rúa. Las críticas de algún concejal al estorbo para la circulación que ocasionaban los soportales, calificados como "remiendos arqueológicos", confirman la todavía desfavorable consideración hacia estos elementos tan característicos del ambiente urbano compostelano, traducida en demoliciones sistemáticas como las que anteriormente habían afectado a los números 8-10 y 25 de la misma rúa do Vilar sólo entre los meses de junio a julio de 1888, o los números 76 a 78 en 1917. AHUS. Fondo municipal. Libros de actas municipales. Año 1922, sesiones del 8 y 9 de agosto, fols. 98 a 100 y 103 a 104.

${ }^{81}$ Se trataba del grupo de casas que todavía alcanzó a ser captado en fotografías de comienzos del siglo XX, como la que comenta Rosende Valdés al abordar precisamente la tensión entre mantenimiento o eliminación de soportales en la estructura urbana de Santiago durante el Antiguo Régimen. Rosende Valdés, op. cit., pp. 101-110. En los primeros meses del año 1917 se consumó la desaparición de estas casas, que ocupaban los números 52, 54 y 56. AHUS. Fondo municipal. Libros de actas municipales. Año 1917, sesiones del 25 de abril y 12 de septiembre, fols. 64 y 118 . 
82 Rey Soto, "Los soportales de Santiago"... Sobre la tradición de los soportales en las ciudades españolas, y en concreto el origen medieval de los soportales compostelanos, con su "aire más solemne y sombrío", se ha ocupado A. Bonet Correa, "Los soportales en las ciudades españolas" en Libro de los amigos de José Luis Barros, Ediciós do Castro, Sada-A Coruña, 1990, pp. 4756; y también en El urbanismo en España e Hispanoamérica, Cátedra, Madrid, 1991, pp. 77-88.

${ }^{83}$ Con respecto a los argumentos de Rey Soto para la defensa de los soportales, la tardía pervivencia de las ideas positivistas de Taine en cuanto a la adecuación de la vida humana y sus producciones a los condicionantes de medio físico, clima y raza reaparecerá en otras tomas de posición similares a cargo de Emilia Pardo Bazán y Castelao. "Exposición de arte gallego..."; y "Labor cultural. Castelao en La Oliva", Faro de Vigo, 10/04/1919, p. 1.

84 Las consideraciones estéticas, inseparables del urbanismo higienista desde el siglo XVIII, se habían utilizado también en el siglo XIX para condenar unos soportales que tenían "muy poco que agradecer al arte y a la higiene", tal como opinaban Fernández Sánchez y Freire Barreiro, op. cit., t. I, p. 169. La réplica concluía reivindicando el derecho de la ciudad a evolucionar pero sin perder su "ambiente señorial". M. Devesa, "Los Porches de la ciudad", Diario de Galicia, 12/08/1922, p. 1. El ambiente de las rúas compostelanas y sus soportales fue integrado por Unamuno en su impresión sobre la sombría hermosura de la ciudad, descrita como "un gran bosque oscuro de piedra" en 1912; mientras que unos años más tarde, en 1926, el ingeniero alemán Oskar Jürgens se pronunciaría con claridad a favor de la permanencia de estas "acogedoras calles asoportaladas", lamentando los huecos e interrupciones ya demasiado visibles en las rúas Nova y do Vilar. M. de Unamuno, Andanzas y visiones de España, Alianza editorial, Madrid, 1988, pp. 92-100; y O. Jürgens, Ciudades españolas. Su desarrollo y configuración urbanistica [Hamburg, 1926], Ministerio de Administraciones Públicas, 1992, p. 117.
85 "La vida contemporánea", LIA, 31 de julio de 1916, n² 1805, p. 490.

${ }^{86}$ En el caso del casco histórico compostelano se rastrean diversos documentos en los que se evidencia la expansión de los enlucidos de cemento, como en la casa número 29 de la rúa do Vilar, en la que con motivo de unas obras de reforma se autorizó sustituir el caleado primitivo por cemento imitando piedra. AHUS. Fondo municipal. Libros de actas municipales. Año 1920, sesión del 29 de septiembre, fol. 99.

87 Emilia también comentaba jocosamente que había llegado a encontrar reproducciones de cuadros al óleo hechas en cemento. Aunque no identificaba esa muestra de mal gusto, sin duda estaba pensando en El Pasatiempo de Betanzos: un parque concebido por el indiano Juan García Naveira y realizado entre 1893 a 1914, en el que se incluyeron varias escenas históricas, bíblicas y de libros de ciencias naturales como ilustración para los niños y curiosos que lo visitaran. I. Cabano Vázquez, M. L. Pato Iglesias, X. Sousa Jiménez, El Pasatiempo. O capricho dun indiano, Ediciós do Castro, Sada-A Coruña, 199; y M.L. Sobrino Manzanares, "Capricho enciclopédico de un indiano: El Pasatiempo de Betanzos (La Coruña)" en Escultecturas margivagantes: la arquitectura fantástica en España (J. A. Ramírez, dir.), Siruela, Madrid, 2006, pp. 72-84

${ }^{88}$ La tesis doctoral de J.R. Iglesias Veiga ha abordado exhaustivamente ésta y otras claves para la afirmación del regionalismo, en una rigurosa investigación que aclara buena parte del panorama de la arquitectura gallega en los años veinte a treinta. Las críticas al cemento y a las formas de la arquitectura moderna sirvieron entonces para la idealización del modo de vida y construcciones tradicionales de Galicia, como en las opiniones expuestas por Castelao -"Arte y galleguismo", 1919, Ramón Otero Pedrayo -Encol da Aldeia, 1922-, Vicente Risco -Mitteleuropa, 1930- o Felipe Bello Piñeiro -" Tres conferencias y un mitin por tierras ferrolanas", 1933. Iglesias Veiga, op. cit., pp. 67, 88, 89 y 303; y del mismo "Arquitectura regionalista en Galicia: de la mirada al románico a la revalorización del barroco", Espacio, Tiempo y Forma, serie VII, Historia del Arte, t. 25, 2012, pp. 245-274.

89 En aquellos mismos años diez se estaba iniciando en España la valoración de la arquitectura popular, las construcciones sin autor conocido o, como se decía entonces, "sin nombre". Textos como los de Manuel B. Cossio -Elogio del Arte Popular (1913)-, Azorín -El paisaje de España visto por los españoles (1917)-, Leopoldo Torres Balbás -Memoria sobre la arquitectura popular en las diferentes regiones de España (1923)-, o incluso los artículos sobre viejas ciudades publicados por Ortega Munilla en la revista Raza española desde 1919 -Siguenza, Medinaceli, Atienza...- fueron decisivos en este sentido, tal como indica Isac, op. cit., p. 354. En Galicia, el estudio y valoración de la arquitectura popular tuvieron como pionero al polígrafo Ángel del Castillo -Riqueza monumental y artística de Galicia (1921), El patrimonio artístico de Galicia (1926)-, al que siguieron arquitectos e historiadores como Antonio Palacios, Rafael González Villar, Xaquín Lorenzo, Florentino López Cuevillas, Fermín Bouza Brey o Xosé Ramón Fernández Ojea. A. Vigo Trasancos, "Ángel del Castillo (18861961). Una vida dedicada al estudio y a la defensa del patrimonio artístico de Galicia" en Inventario de la Riqueza Monumental y Artística de Galicia (A. del Castillo), Reed. Fundación Pedro Barrié de la Maza, A Coruña, 2008, t. I, p. 84; e Iglesias Veiga, La tendencia regionalista..., pp. 177-179.

${ }^{90}$ En cambio, cuando se sustituía ese caserío tradicional advertía sobre el peligro de las soluciones más estereotipadas de la arquitectura residencial moderna, a la que acusaba de "hibridaciones sin alma" y de "industrialismo". "Exposición de arte gallego..." La alusión de Emilia al "industrialismo" no debe entenderse como una simple referencia a los materiales de producción en serie, ya que podría aplicarse a todo el abanico de cambios vinculados con el capitalismo y la especulación modernas, tal como los retrataba apocalípticamente Azorín en un texto de 1901: "Hay una barbarie más hórrida que la barbarie antigua: el industrialismo moderno", Diario de un enfermo, Tipografía de Ricardo Fe, Madrid, 1901, p. 29. 
91 "Exposición de arte gallego...". Días antes Antonio Palacios, uno de los impulsores de la exposición, en declaraciones al mismo diario La Voz de Galicia había abogado también por el respeto a la "arquitectura tradicional gallega": A. Garrido Moreno, El arquitecto Rafael González Villar, Diputación Provincial de A Coruña, 1998, p. 150. En cuanto a la conferencia de Emilia Pardo Bazán, se ha recogido también en J.A. Sánchez García, "Séculos XIX e XX" ..., pp. 1329-1330; e Iglesias Veiga, op. cit., pp. 903-904.

92 En 1885 había asistido a la reunión del Folklore Internacional celebrada en París, un modelo que ella misma intentó importar a Galicia con la creación de la Sociedad del Folklore Gallego, fundada en 1884 para recoger y conservar todas las manifestaciones del saber popular, que comenzó sus sesiones en su propia casa coruñesa de Tabernas. E. Pardo Bazán y S. Golpe, El Folk-lore gallego en 1884-1885. Sus actas $y$ acuerdos $y$ discursos, Est. Tip. de Ricardo Fe, Madrid, 1886, pp. 6 y 19; P. Faus, Emilia Pardo Bazán. Su época, su vida, su obra, Fundación Pedro Barrié de la Maza, A Coruña, 2003, vol. I, pp. 272-276. Gracias a sus amistad con destacadas figuras de la Renaixença, Emilia tuvo la oportunidad de visitar en el verano de 1895 la casa-museo Cau Ferrat de Sitges, donde el pintor Santiago Rusiñol estaba reuniendo una variopinta colección de piezas artesanales de hierro, cerámica, vidrio, mobiliario, tallas y pinturas, lo que supuso un acicate para el posterior interés de la escritora gallega por la creación artística. E. Pardo Bazán, "El Cau Ferrat", La Época, 25/09/1895, p. 2, citado por Faus, op. cit., vol. II, pp. 93-96.

${ }_{93}$ No se debe pasar por alto que en sus novelas más concordantes con las técnicas de observación naturalistas Emilia recurrió a una cierta incidencia del ambiente físico y social sobre el carácter y conducta de las personas, tal como se puede detectar en Los pazos de Ulloa (1886) y sobre todo La madre naturaleza (1887). D. Villanueva, "Los Pazos de Ulloa, el naturalismo y Henry James", Hispanic review, Vol. 52, n. 2, Spring 1984, pp. 121-139; M.R. Saurín de la Iglesia, Naturalismo e storia regionale, Montefeltro edizioni, Urbino,
1985, pp. 8-9; y Faus, op. cit., Vol. I, p. 374. La posibilidad de extender el determinismo biológico de Zola al determinismo físico y climático sobre la arquitectura, de nuevo con el trasfondo de las ideas de Taine, podría estar alimentando algunas de estas argumentaciones. En este sentido, Estévez Ortega no sólo reprodujo y asumió las palabras de Emilia sino que definió la nueva "escuela artística gallega" desarrollada a partir de 1909 por la íntima compenetración con los elementos vernáculos y la culminación de una serie de tradiciones literarias, arquitectónicas, escultóricas, a las que se iba a añadir la nueva y genuina corriente pictórica. E. Estévez Ortega, Arte gallego, Lux, Barcelona, 1930, pp. 8-9 y 137138; citado también por Iglesias Veiga, op. cit., p. 95.

${ }^{94}$ Rucabado y González abrieron esta ponencia con una frase de Menéndez Pelayo tomada de su Historia de las Ideas Estéticas en España (1883-1891), erudito al que Emilia admiraba, y por supuesto leía con muchísima atención, acerca de que "No se inventan artificialmente nuevos modelos de Arquitectura, arte el más colectivo y el más indócil de todos al capricho individual". Isac, op. cit., pp. 346-348.

${ }_{95}$ Aunque la pretenciosa morada siguiera pautas inglesas en cuanto a la distribución interior, con un espacioso hall para la exhibición de los signos de abolengo de la familia propietaria, en su decoración abundaban los guiños a la tradición del arte medieval gallego, como en la portada neorrománica de la capilla, con su tímpano inspirado en la parroquial de Santiago de A Coruña, o el sepulcro de la propia escritora, reinterpretando los túmulos de San Francisco de Betanzos que conocía tan bien. J.A. Sánchez García, "Las Torres de Meirás. Un sueño de piedra para la quimera de Emilia Pardo Bazán", Goya, n 332, Julio-Septiembre 2010, pp. 228-245.

96 "Exposición de arte gallego. Una reunión", LVG, 3/09/1917, p. 1. Probablemente fueron Antonio Palacios y el secretario de la comisión organizadora de la exposición, el historiador Ángel del Castillo, los más interesados en esta iniciativa, que tuvo una inmediata ejecución con el telegrama enviado por Palacios, junto con los pintores
Sotomayor y Lloréns, al Director general de Bellas Artes felicitándole por la orden emitida para paralizar las obras de demolición que se estaban llevando a cabo en el convento de San Francisco de Betanzos. "La exposición de arte gallego", LVG, 05/09/1917, p. 1. El abandono y ruina de este convento se venía aprovechando por el ayuntamiento local ya desde el año 1874 para promover continuas demoliciones que acabaron ocasionando la pérdida de su claustro. En el verano de 1916 la comunidad franciscana había iniciado las obras para levantar su nueva residencia adosada al templo, escapando al control de la Comisión Provincial de Monumentos, lo que justificó diferentes denuncias oficiales, tal como analizó en su momento I. Calvo Mosquera, El camino en la valoración del patrimonio histórico-artístico. Criterios para la declaración de monumentos en la provincia de A Coruña desde 1836 hasta 1936, Tesina de Licenciatura, Universidad de Santiago de Compostela, 2002, pp. 156-165.

97 Una crónica publicada en la prensa local de aquellos años, firmada con el seudónimo que utilizaba el periodista Alfredo Tella Comas, era tajante al afirmar esta percepción de una ciudad sin casco histórico que valiera la pena -"la Coruña no es un pueblo histórico, ni mucho menos"-, para elogiar en cambio zonas de la ciudad de los siglos XVIII y XIX como la calle Real, los Cantones o la plaza de María Pita. En el mismo artículo se apuntaba que $A$ Coruña, como otras ciudades gallegas, sí contenía estampas de "pueblo gallego típico, con algo de pesca y algo de mercado", pero concentradas en arrabales como "el Campo de la Leña, las Atochas, Orillamar y calle de la Torre, donde se salta bruscamente de la casa de vecindad al lugar acasarado, con palleiro, hórreo y todos los demás requisitos absolutamente rurales". Equis, "Croniquilla. El arcano", El Noroeste, 14/12/1917, p. 1. En cuanto a la "falta de grandes monumentos", ya había sido señalada por Emilia Pardo Bazán en la fisonomía urbana que describió en 1878: González Herrán, J.M., "Fisonomía de Marineda en un olvidado artículo de Emilia Pardo Bazán (1878)", La Tribuna, № 7, 2009, pp. 139-168 
98 Como ya se ha indicado, en 1840 se había iniciado el derribo de las murallas de la Ciudad Vieja, concluido a lo largo de la segunda mitad del XIX. En la misma parte antigua de la población los soportales fueron erradicados sistemáticamente como consecuencia de las actuaciones del urbanismo de la Ilustración, desde la puesta en marcha en 1791 de la Junta de Policía Urbana. A. Vigo Trasancos, A Coruña y el Siglo de las Luces. La construcción de una ciudad de Comercio (1700-1808), Universidade de Santiago de CompostelaUniversidade da Coruña, 2007, pp. 311-316.

${ }_{99}$ El caso coruñés presenta gran similitud con lo ocurrido en otras ciudades cantábricas de parecido perfil como núcleos industriales y de servicios -Gijón, San Sebastián. En cuanto a la negativa percepción sobre su conjunto histórico, podría apuntarse incluso un paralelismo con Turín, como ciudad en la que, a falta de un relevante patrimonio arquitectónico heredado, el desarrollo industrial y dinamismo económico del cambio de siglo la convirtieron en terreno abonado para la difusión del modernismo. Estas fueron las razones que llevaron a escogerla como sede para la Prima Esposizione Internazionale d'Arte Decorativa Moderna (1902), acontecimiento clave en la consolidación de la versión italiana del modernismo conocida como Liberty. R. A. Etlin, Modernism in Italian Architecture, 1890-1940, Massachusetts Institute of Technology, 1991, p. XV.

${ }^{100}$ A. Garrido Moreno, "La galería gallega: una tipología tradicional en permanente evolución", Anuario Brigantino, n² 21, 1998, pp. 379-404; y J.A. Sánchez García, "En el balcón, en el palco, en la galería. Estrategias de la mirada en la arquitectura del siglo XIX", Semata. Ciencias Sociais e Humanidades. En femenino. Voces, miradas, territorios, vol. 20, 2008, pp. 329-350. Con el apoyo incondicional de los propietarios, ni las reticencias de las autoridades ni los reparos estéticos de los arquitectos académicos fueron suficientes para impedir su desarrollo. Como muestra véase el protagonismo de este amueblamiento de fachada en la arquitectura residencial proyectada a lo largo del XIX por el arquitecto Fausti- no Domínguez Domínguez, quien precedió a Juan de Ciórraga, otro técnico foráneo, en la acomodación y expansión de las galerías. J.A. Sánchez García, Faustino Domínguez Domínguez y la arquitectura gallega del siglo XIX, Diputación Provincial de A Coruña, 1997, pp. 159-186.

101 Algunos artículos publicados en aquellos años criticaban incluso las construcciones residenciales decimonónicas por su abuso de las galerías, debido a la monótona y repetitiva imagen que habían trasladado a la estética urbana: "Cómo crece La Coruña. Obras nuevas", LVG, 17/09/1903, p. 1; "La construcción en La Coruña. Medio siglo de mala arquitectura", LVG, 07/12/1903, p. 1. De hecho, además de aceptar con entusiasmo las novedades formales que introducía el modernismo se presumía de los viajes de arquitectos e industriales locales a estudiar la arquitectura europea, llegándose a copiar la política de concursos para las mejores fachadas -Concours de Façades- que venían celebrándose en París desde 1898. "La construcción en La Coruña. Renacimiento artístico", LVG, 07/06/1907, p. 1; "La construcción en La Coruña. En busca de nuevos rumbos", LVG, 21/11/1908, p. 1.

102 Pisa-Flores, "La calle de Fonseca ¿debe prolongarse?", LVG, 13/12/1902, p. 1. Debido a la inicial oposición de los propietarios el proyecto se retrasó hasta los años veinte, siendo en 1926 cuando se comenzó a valorar el coste de las expropiaciones, trazando Pedro Mariño, Antonio Tenreiro y Peregrín Estellés los primeros planos y propuesta de edificios, incluyendo una versión de calle con cubierta acristalada en julio de 1927. F. Agrasar Quiroga, Antonio Tenreiro, 1893-1972. Obra arquitectónica, COAG, A Coruña, 2007, pp. 42-43.

103 Tal como destacaba ya M.C. Morales Saro, Gijón 1890-1920. La arquitectura y su entorno, Ayuntamiento de Gijón, 1978, pp. 29 y 51-72.

104 Un testimonio de viajero, el del escritor madrileño Alfonso Pérez Nieva, era totalmente explícito al comentar "No hay que buscar en Vigo monumentos artísticos ni recuerdos históricos. Es una ciudad sin tradición, sin ayer que la ilumine con los reflejos del pasado". A. Pérez Nieva, Por las Rías Bajas (1900), reproducido por M.A. Leboreiro Amaro, Vigo, puerto y destino. Atlas urbanístico de Vigo, COAG, Vigo, 2000, p. 67.

$105 \mathrm{~J}$. Garrido Rodríguez, El puerto de Vigo. Sintesis histórica, Autoridad Portuaria, Vigo, 2001, pp. 131-150.

106 Idea apoyada públicamente, destacando el valor del Berbés como "monumento racial", por el empresario e intelectual galleguista Valentín Paz Andrade, "La ciudad. El progreso y el arte", Faro de Vigo, 01/02/1927, p.1. Comentado también por Iglesias Veiga, op. cit., pp. 185-186.

${ }^{107}$ En Castrelos se reunirían, además, otras edificaciones antiguas que se considerara oportuno salvar de la casi total demolición del casco histórico que contemplaba su plan, tal como explicó en su conferencia: "Sociedad de Amigos del Arte. Conferencia de D. Antonio Palacios", El Pueblo Gallego, 13 y 15/01/1933, p. 6, según recoge Iglesias Veiga, op. cit., pp. 170-171. La contradictoria posición de Palacios, en quien convivieron la investigación y defensa del patrimonio con excesos neobarrocos a la hora de proyectar arrasamientos de tejidos históricos, desde este Plan para Vigo a la propuesta de Rúa de Galicia en Santiago de Compostela, merecería una atención específica que escapa al objetivo de este artículo.

108 Isac matiza que estos planteamientos conectaban, aunque fuera tardíamente, con las ideas sobre urbanización artística y preservación de la estética urbana preconizadas años atrás por Baumeister, Stübben, Buls o Sitte. Isac, op. cit., pp. 330-331.

109 Torres Balbás ponía como ejemplo lo ocurrido en Granada con la apertura de su Gran Vía ya comentada en la nota $n^{\circ} 35$. L. Torres Balbás, Legislación, inventario y organización de los Monumentos históricos y artísticos de España (1919), según la referencia tomada de Isac, op. cit., p. 372.

110 Elegido el escultor Mariano Benlliure, durante aquel mismo año 1914 se activó la captación de fondos mediante una suscripción popular y aportaciones de instituciones como el Congreso, el Senado, el Ministerio de 
Hacienda o el Banco de España, además de las cuatro diputaciones y varios concejos de Galicia, sobre todo los que controlaban los políticos "monteristas". Barral Martínez, op. cit., pp. 330-352.

${ }^{111}$ En la contestación de Benlliure por carta del 31 de mayo de 1914 a una primera misiva del alcalde, le notificaba que había acordado con Eugenio Montero Villegas que el mejor emplazamiento era la plaza del Toral. Sin embargo, cuando a finales del mes de agosto se trasladó a Galicia para verificar esta ubicación, el escultor quedó decepcionado ante su escasa amplitud, decidiendo que sería la plaza del Hospital, actual Obradoiro, el lugar más adecuado por su importancia y belleza para interpretar el sentir popular de homenajear al hijo más ilustre de Compostela. AHUS. Fondo municipal. Monumento a Montero Ríos, antecedentes, 1913-1922. Actas de la Comisión Gestora del Monumento, sesión del 9 de diciembre de 1914.

${ }^{112}$ Esta solicitud tenía por fin contrarrestar un condescendiente dictamen de la Academia de Bellas Artes de San Fernando, emitido en mayo de 1915 a petición del Ayuntamiento compostelano: "nada puede temerse que el día en que se halle en el sitio que se le ha señalado para su erección [el monumento], entorpezca las perspectivas verdaderamente notables que la plaza de Alfonso XII de Santiago presenta por todos sus frentes, antes bien es seguro que ha de contribuir a dar a aquellas su verdadero valor, afirmando las dimensiones reales de tan amplia plaza, no siendo posible tampoco pensar que el trazado de ese monumento pueda ocultar ni desfigurar las bellezas de los edificios notabilísimos que cierran aquel espacio”. Reproducido por Barral Martínez, op. cit., p. 341. En cambio, el informe del Barón de la Vega de Hoz, encargado por la Academia de la Historia para resolver la cuestión trasladada por la Dirección General de Bellas Artes, fue favorable a la solicitud de los vecinos. Según la documentación -Real Academia de la Historia, Comisión de Antigüedades. Galicia, CAC/9/7953/23(2)- consultada por Calvo Mosquera, op. cit., pp. 168-169.

${ }^{113}$ Villar Iglesias (1879-1949) fue un médico, especialista en urología, que ejerció desde 1905 como profesor en la Facultad de Medicina de la Universidad de Santiago, ciudad en la que también tuvo un sanatorio, donde trató a Ramón del Valle-Inclán, y llegó a ser presidente del Colegio Médico, de la Liga de Amigos, e incluso alcalde entre abril a octubre de 1930. Durante los años veinte participó activamente en diferentes reivindicaciones de interés regional como el restablecimiento de la Escuela de Veterinaria o la creación de la Residencia de Estudiantes, siendo objeto de un expediente de depuración, posteriormente anulado, por haber accedido al cargo de secretario de la Facultad de Medicina en fechas previas al golpe militar de 1936 . R. Gurriarán, Ciencia e conciencia na Universidade de Santiago (1900-1940): do influxo institucionalista e a JAE á depuración do profesorado, Universidade de Santiago de Compostela, 2006, pp. 282-283 y 620-621.

114 Siendo alcalde Máximo de la Riva García, su propuesta fue apoyada por el concejal Raimundo López Pol, otro de los hombres fuertes del consistorio, transmitiéndose a la Comisión de Obras. AHUS. Fondo municipal. Libros de actas municipales, año 1919, fol. 36.

115 "Noticias de Galicia. Santiago", El Noroeste, 31/10/1910, 1. Sus actuales descendientes no han podido aportar más información sobre esta faceta de su actividad pública, aunque también pudiera ser reveladora la contratación del prestigioso arquitecto catalán Enrique Sagnier Villavecchia para diseñar en 1914 la casa familiar en la calle Fuente de San Antonio 2, colindante con el edificio de la Inquisición que había sido derribado en 1913. Sobre esta curiosa vivienda ecléctica, con el consultorio médico en la planta baja y una singular galería de esquina, véase la ficha en Costa Buján y Morenas Aydillo, op. cit., pp. 222-223.

${ }^{116}$ Natural de Toledo y titulado por la Escuela de Arquitectura de Madrid en 1914, desde noviembre de aquel mismo año Ragel obtuvo el nombramiento como arquitecto municipal de Santiago de Compostela, plaza que ocupó hasta 1923. Costa Buján y Morenas Aydillo, op. cit., p. 397. Tras el precedente del Salón Teatro es curioso comprobar que años más tarde, en 1921, Fernández Ragel modificó la fachada de otro edificio proyectado por López de Rego, en este caso para la familia Gutiérrez de la Peña en la plaza del Toral (1907), sustituyendo su composición y ornamentos modernistas por una solución que en su frontón semicircular con escudo y pináculos recuperaba el tono de palacete compostelano juzgado como más conveniente para su armonización urbana.

117 AHUS. Fondo municipal. Licencias de obras, año 1919. "Expediente instruido a instancia de la Sociedad Liga Mutua de Señoras-Caja de Ahorros y Préstamos, solicitando licencia para reconstruir la casa num. 34 de la Rua Nueva", fols. 176 y ss. Circunstancias comentadas ya en J.A. Sánchez García, La arquitectura teatral en Galicia, Fundación Pedro Barrié de la Maza, A Coruña, 1997, pp. 434-439; y más recientemente en Salón Teatro. Corazón do espectáculo, Consorcio de Santiago-Alvarellos, 2013, pp. 62-68.

${ }^{118}$ En la sesión municipal del 7 de mayo Villar Iglesias insistió sobre el mismo asunto de reformar las Ordenanzas municipales, buscando "que las construcciones dentro del casco de la ciudad, deben acomodarse al estilo característico de cada vía", a la vez que se quejaba de la licencia aprobada el 27 de abril para el Salón Teatro, "cuyo estilo, según el plano presentado, desdicirá [sic] notoriamente del resto de las edificaciones". El alcalde le contestó que de acuerdo con las ordenanzas vigentes no había podido denegarse la licencia, pero que sí se había consignado la sugerencia de reformar la fachada proyectada. AHUS. Fondo municipal. Libros de actas municipales. Año 1919, sesión del 7 de mayo, fols. 47 y 48 . Es importante anotar que, en el contexto europeo, Inglaterra disponía ya desde 1909 de una precoz normativa para el control estético municipal sobre las nuevas edificaciones que debían concordar con las antiguas en cuanto a diseño o materiales, tendencia a la que se incorporó Francia en el período 19191930: J. Punter, "A history of aesthetic control: Part 1, 1909-1953: the control of the external appearance of development in England and Wales", Town Planning Review, 57:4 (Oct. 1986), pp. 351-381. 
${ }^{119}$ Años más tarde, la declaración de Santiago como conjunto histórico marcó también el inicio de una deliberada política para el mantenimiento e incluso restauración de la imagen "típica" del caserío compostelano, ahora en la vertiente más "fachadista", a través de las intervenciones planificadas por el arquitecto-conservador Francisco Pons Sorolla que ha estudiado Castro Fernández, op.cit; y de la misma autora "Santiago de Compostela: embalsamiento, musealización y "culto" de una ciudad histórica (1954-1971)", Compostellanum, Vol. 53, №. 3-4, 2008, pp. 557-590; y "Del culto a la fachada a la "ciudad escaparate" en Mirando a Clío: el arte español espejo de su historia. Actas del XVIII Congreso del CEHA, Santiago de Compostela, 20-24 de septiembre de 2010, M.D. Barral Rivadulla, E. Fernández Castiñeiras, B. Fernández Rodríguez, J.M. Monterroso Montero, Coords., USC, 2012.

${ }^{120}$ La personal exploración de una arquitectura de referencias medievales que sirviera para articular una opción regionalista se analiza en Iglesias Veiga, op. cit.; y del mismo La tendencia regionalista..., p. 882

121 La maduración de la opción regionalista fue haciéndose presente en relevantes proyectos institucionales como la sede de la Delegación de Hacienda de A Coruña (Miguel DuránLoriga, 1926), el pabellón de las cuatro provincias gallegas en la Exposición Iberoamericana de Sevilla de 1929 (Miguel Durán-Loriga), o la Residencia de Estudiantes de Santiago, actuales colegios mayores del Campus Sur (Jenaro de la Fuente Álvarez, 1930). El lenguaje formal inspirado en el barroco se aplicó también a numerosas edificaciones privadas en zonas de veraneo y periferias urbanas, como se ha destacado en J.A. Sánchez García y J.R. Iglesias Veiga, "Bases ideológicas para la recuperación del pazo gallego en los años 30" en Actas Arquitectura, ciudad e ideología antiurbana, Universidad de Navarra, 2002, pp. 123-132; e Iglesias Veiga, op. cit., pp. 278-311.

122 Nacido en A Guarda, durante su juventud realizó temporadas de estudios en Francia, Inglaterra y Alemania, entablando posterior amistad con algunos de los líderes del pensa- miento conservacionista en España, como Leopoldo Torres Balbás, además de historiadores como Manuel Gómez Moreno y Francisco Javier Sánchez Cantón. B. Soneira Beloso, O arquitecto Constantino Candeira, Ediciós do Castro, Sada-A Coruña, 2006, p. 24. Su discurso de ingreso en el Seminario de Estudios Gallegos, el 23 de octubre de 1926, consistió en una "Síntesis de la evolución del barroco en Santiago" muy elogiada por Ramón Otero Pedrayo. Iglesias Veiga, "Arquitectura regionalista..."

123 Candeira pensaba además que era esencial establecer una comisión consultiva para asesorar al Ayuntamiento sobre todas las cuestiones estéticas que pudieran implicar los permisos para nuevas edificaciones en el casco histórico, "desde los faroles y rótulos hasta el estilo y aspecto de las construcciones". Según sus reveladoras palabras, en carta dirigida en agosto de 1924 a Sánchez Cantón, nada más acceder al puesto de arquitecto municipal: "Estoy intentando reformar las Ordenanzas Municipales y quisiera declarar intangible el aspecto de las calles dentro del antiguo recinto". Esta llamativa percepción del ambiente urbano como algo "intangible" podría derivar de la valoración de John Ruskin sobre las ciudades antiguas como objeto patrimonial intangible, tal como se encuentra en The Seven Lamps of Architecture (1849) o The Opening of the Crystal Palace (1851), según la referencia aportada por Choay, op. cit., p. 165. En otra muestra de su contacto con las tendencias conservacionistas, Candeira comentaba también que su modelo era la política aplicada en ciudades como Nuremberg, de la que estaba intentando obtener copia de sus ordenanzas, e igualmente Berna y Friburgo. De hecho llegó a visitar estas dos localidades suizas durante el corto permiso que le concedió el Ayuntamiento aquel verano de 1924, cuando tenía intención de participar en la Conferencia Internacional de Ciudades y Congreso de Urbanización a celebrar en Amsterdam, a lo que finalmente renunció por no disponer de tiempo suficiente. Soneira Beloso, op. cit., pp. 33-35.

${ }^{124}$ Sobre esta faceta más operativa de Giovannoni véase Choay, op. cit., p.
187; y también F. Ciardini, P. Falini, "La actuación pública en los centros históricos" en Los centros históricos..., pp. 115-147;

125 R. Otero Pedrayo, "Domingos Literarios de Galicia", Galicia, 18/07/1926; artículo reproducido en Soneira Beloso, op. cit., pp. 15-17. La imagen poética que traza de Candeira como "xardineiro das pedras" se completa en otro texto posterior -"Amigos de onte e de sempre. Constantino Candeira", LVG, 18/02/1975, p. 20- con la evocación del casco viejo de Compostela como una "mesta e rumorosa carballeira arquitectónica", citado también por Soneira Beloso, op. cit., pp. 17-19. Al hilo de estas metáforas conviene señalar que Candeira fue el responsable de la renovación del pavimento de la plaza de la Quintana, aprobado en diciembre de 1924, con un delicado diseño geométrico y cuidada cantería que merecieron un unánime reconocimiento y elogios.

${ }^{126}$ Abogado de ascendencia hidalga, su etapa en la alcaldía compostelana, que prácticamente coincidió con la dictadura primoriverista, se inició en enero de 1924, caracterizándose en lo político por la reacción para anular la influencia de los últimos partidarios de Montero Ríos, con gestos tan elocuentes como la reubicación, ya comentada, de su monumento en 1928. Villares Paz, op. cit., pp. 537-538. En cuanto a la promoción turística de la ciudad, al poco de tomar posesión Díaz-Varela presentó una moción para afirmar la significación de Santiago como "ciudad internacional" y "centro cultural" que atraía un flujo de peregrinos y turistas, lo que debía orientar las mejoras en los medios de transporte y actuaciones de propaganda como el encargo en 1926 de una película para ser exhibida durante la Exposición Iberoamericana de Sevilla de 1929. AHUS. Fondo municipal. Libros de actas municipales. Año 1924, sesión del 21 de enero, fols. 8-9; y año 1926, sesión del 26 de febrero, fol. 52.

${ }^{127}$ Al margen del variable ritmo de celebración de Años Santos es posible que se estuviera teniendo en cuenta el modelo de promoción turística de grandes ciudades como Barcelona, donde la Sociedad de Atracción de 
Forasteros, creada en 1914, se vinculó con iniciativas como la elaboración de un primer mapa de monumentos a visitar, en un pionero ejemplo de una cartografía urbana que recogía las nuevas perspectivas de la mirada patrimonial. T. M. Sala, "Imágenes de la ciudad de la vida moderna: ideales, sueños y realidades" en Barcelona 1900, Lunwerg, Barcelona, 2007, p. 22.

${ }^{128}$ Nacido en Santiago en 1869, Magariños fue un ferviente admirador del pasado medieval de Compostela, etapa en la que a su juicio se había conformado como "acrópolis del cristianismo que ha servido de faro a los artistas de todos los tiempos", denostando en cambio la impronta monumental aportada por el "herrerismo y barroquismo", a su juicio origen de una decadencia que habría culminado a finales del XIX, cuando las dinámicas de la ciudad burguesa "fueron transformando nuestra ciudad hasta el caso de pretender convertirla en rival de las ciudades modernas cuya finalidad era el comercio y en esto estriba la equivocación de nuestras gentes". Texto tomado de documentos del archivo familiar que reproduce F. Pérez Benítez, Escultor Maximino Magariños Rodríguez http:// escultormaximiniomagarinos. blogspot. com.es/ [Acceso: 15/05/2013]

${ }^{129}$ Esta idea se inspiraba seguramente en precedentes como el concurso de fachadas de casas de estilo sevillano propuesto en Sevilla en 1910 y regulado finalmente en 1912, que aunque no llegara a concretarse mereció amplia difusión y elogios a nivel nacional; o el concurso de temas de interés para Galicia convocado en 1921 desde la revista Mondariz, entre los que figuraba una sección sobre las variantes de la "antigua casa gallega". A. Villar Movellán, Arquitectura del Regionalismo en Sevilla, 1900-1935, Diputación de Sevilla, 2010, p. 238; Iglesias Veiga, "Arquitectura regionalista..."

130 AHUS. Fondo municipal. Actas de la Comisión Permanente, Febrero 1925-Julio 1926. Sesión del 19 de agosto de 1925, fols. 99 a 101. Pese a que se designó una comisión de miembros de la corporación y ciudadanos para redactar las bases del citado concurso-exposición y otras ideas para la conservación de la ciudad, la iniciati- va nunca se llevó a pleno, cayendo en el olvido. Entre los miembros de aquella comisión estaba Celestino Sánchez Rivera, director de El Eco de Santiago, quien venía utilizando las columnas de su periódico para sensibilizar sobre distintos aspectos de la historia y el patrimonio de Compostela, lo que le valió el posterior nombramiento como Conservador de los Monumentos Nacionales de Santiago. C. Sánchez Rivera, Notas compostelanas, Librería y editorial Sucesores de Galí, Santiago de Compostela, 1945, p. XXI.

131 Para esta misma etapa es necesario señalar que Ángel del Castillo, en su síntesis sobre "La Arquitectura en Galicia", explicitaba ya una franca preocupación por la carencia de estudios sobre unas tipologías de arquitectura civil que merecían completarse con otras investigaciones sobre el "trazado de las villas antiguas de Galicia", según señala Vigo Trasancos, op. cit., p. 100. A. del Castillo, "La Arquitectura en Galicia" en Geografía General del Reino de Galicia (F. Carreras Candi, ed.), Barcelona, Alberto Martín, 1936, t. 2, pp. 829-1093.

132 Le había precedido en el cargo, como arquitecto municipal interino, Antonio de Cominges, responsable del diseño del regionalista Hotel Compostela. Titulado en 1929, Banet formó parte del grupo de arquitectos que introdujeron la arquitectura racionalista en la Galicia de comienzos de los años treinta, junto a Santiago Rey Pedreira, José Caridad Mateo, Eloy Maquieira, Francisco Castro Represas o Antonio Alés Reinlein. Gracias a sus frecuentes viajes a Francia, desde la terminación de sus estudios y por la nacionalidad francesa de su esposa, Banet pudo establecer contacto directo tanto con los postulados de la vanguardia arquitectónica como con las tendencias en la conservación del ambiente urbano. Costa Buján y Morenas Aydillo, op. cit., p. 399; y Agrasar Quiroga, Vanguardia y tradición. La arquitectura de la primera modernidad en Galicia, COAG, A Coruña, 2003, p. 47.

133 En cambio, durante los años treinta la opción racionalista fue dominante en sus proyectos para edificaciones en el ensanche. Las memorias para las dos versiones de la fachada de la ci- tada vivienda en la rúa do Vilar insistían en la idea de acomodar el exterior al "carácter dominante en las construcciones de la Rúa" o "armonizar con la nota barroca, típica de la ciudad y principalmente con la de los edificios inmediatos también barrocos", lo que se tradujo en la apertura de un porche decorado en su rosca interior con motivos característicos del barroco de placas, copiados de la cercana Casa del Cabildo de Fernández Sarela. Con una actitud similar, el proyecto de José Caridad Mateo para el bajo comercial instalado en el 21 de la misma rúa do Vilar (1934), optó en cambio por un estilo neorrománico en arcos, columnas, capitel y ménsulas, realizados con la colaboración del escultor Caulonga. Costa Buján y Morenas Aydillo, op. cit., pp. 300-301 y 312-313.

134 Precedida por los años del rector Rodríguez Cadarso al frente de la Universidad, con su política republicana y autonomista, esta etapa se había iniciado en 1931 con la figura del alcalde republicano Raimundo López Pol. Tras las elecciones de 1933, con el ascenso de las derechas al poder, el nuevo contexto vino marcado por la organización de la Asamblea de Municipios de Galicia y los paralelos debates sobre la capitalidad regional, con vistas al proyecto de estatuto de autonomía, que agitaron la cuestión de la preeminencia de Santiago sobre el resto de ciudades gallegas. Villares, op. cit., pp. 519, y 540-541.

135 "A la Excma. Corporación Municipal. Existen legalmente aprobadas alineaciones de calles de nuestra ciudad que acaso pudieran haber respondido a criterios dominantes en los tiempos en que se formaron, pero que en el día de hoy constituyen verdaderos atentados contra el interés público por olvidar el carácter especialísimo de Compostela, buscando la línea recta como base de tales alineaciones, los que las formaron. Por otra parte, aquellas alineaciones llevan años y años sin haber tenido una verdadera realización en perjuicio de los propietarios de fincas en las respectivas calles enclavadas.

Estas consideraciones aconsejaron a la Comisión municipal de Ensanche, Reforma interior y Residencia de Estudiantes a estudiar con el asesoramien- 
to del Arquitecto municipal todas las alineaciones parciales vigentes para formular ante VE propuesta en cada caso, a fin de que se logre que no queden subsistentes más que aquellas que respondan al criterio antes expuesto, esto es, las que tiendan a conservar el carácter típico de Compostela". AHUS. Fondo municipal. Libros de actas municipales. Año 1934, sesión del 20 de diciembre, fol. 214.

${ }^{136}$ Algunas diferencias en el seno de la corporación municipal, debidas a la gestión de otros asuntos, sobre todo los presupuestos para obras municipales, tuvieron que ver con que en este mismo año 1934 se desistiera de la idea de la declaración. El propio Amaro Gómez la retiró del orden del día de la sesión del 27 de diciembre, sin que se llegara a retomar. No obstante, este mismo concejal perseveró en su interés por la promoción de Compostela al proponer en enero de 1935 que, atendiendo a su "carácter monumental... y centro de turismo", se creara un servicio de turismo y propaganda a cargo del Ayuntamiento. AHUS. Fondo municipal. Libro de actas municipales. Año 1935, sesión del 10 de enero, fol . 235. Esta sería su última iniciativa, ya que en abril de 1935 el resto de concejales acordaron retirar su confianza a Braulio Amaro, por las disensiones antes aludidas, solicitándole que presentara su renuncia.

${ }^{137}$ Tras la segunda propuesta presentada en 1935, fue en marzo de 1936 cuando el Ayuntamiento aprobó este proyecto para que pasara a fase de exposición pública, considerando su interés para la "monumentalidad artística" de la ciudad. Un mes más tarde, al no presentarse alegaciones, se produjo su aprobación definitiva, aunque finalmente nunca llegaría a abordarse. AHUS. Fondo municipal. Libros de actas municipales. Año 1936, sesiones del 12 de marzo y 30 de abril, fols. 258 y 311. Los efectos que hubiera tenido esta radical apertura viaria, entendida como eje vertebrador norte-sur, desde Porta Faxeira a Basquiños atravesando la plaza del Obradoiro, se comentan en el exhaustivo análisis urbano de P. Costa Buján, Evolución urbana y cambios morfológicos, Santiago de Compostela 1778-1950, Tesis Doctoral, Universidade de A Coruña, 2013, vol. 2, pp. 120126 , que, pendiente de publicación, se ha podido consultar gracias a la generosidad de su autor.

138 La contextualización de estas y otras intervenciones desarrolladas por Ferrant en Galicia a partir de 1929 puede consultarse en J. Esteban Chapapría y M. P. García Cuetos, Alejandro Ferrant y la conservación monumental en España (1929-1939). Castilla y León y la primera zona monumental . Junta de Castilla y León, 2007, vol. II, pp. 245-452.

139 El proyecto para reformar la fachada abriendo nuevos huecos, junto a otras mejoras interiores, estaba firmado por el arquitecto ecléctico Eduardo Rodríguez-Losada Rebellón, y se presentó en el mes de abril en el Ayuntamiento. AHUS. Fondo municipal. Licencias de obras. Año 1935, Exp. 208. El informe de José María Banet valoró que tratándose de "una vieja casa con fuerte carácter", podía perjudicarse a las características originales de su fachada, opinando que no debía autorizarse el rasgado de huecos en las plantas primera y segunda.

140 Fueron los Sres. Buján Casal, Lorenzo Moure y Arijón Gende. AHUS. Fondo municipal. Libros de actas municipales. Año 1935, sesión del 20 de julio, fols. 76-77.

${ }^{141}$ En la sesión municipal del 14 de mayo el concejal López García solicitó que se redactaran unas nuevas Ordenanzas, idea a la que se sumó el alcalde Ángel Casal, afirmando que ya por su cuenta había pedido las de otras ciudades que "por su tipo y condiciones" se asemejaban a Santiago. AHUS. Fondo municipal. Libros de actas municipales. Año 1936, sesión del 14 de mayo, fol. 332.

${ }^{142}$ En octubre la Comisión Municipal de Fomento apoyó esta derogación, unos meses más tarde de que se produjera, el 26 de mayo, la denegación de licencia al propietario para reformar la fachada del número 43 de la rúa do Vilar si se mantenía su soportal. AHUS. Fondo municipal. Libros de actas municipales. Año 1937, sesión del 6 de octubre, fol. 558. Conviene recordar aquí que el ayuntamiento compostelano había acordado ya el 11 de julio de 1866 el derribo de los soportales en la rúa do Vilar como asunto de "utilidad pública" en aras de las razones higiénicas ya comentadas páginas atrás. El plano de alineaciones de esta rúa do Vilar, formado por el arquitecto municipal Prado y Vallo en octubre de 1870, intentó conciliar este objetivo con el mantenimiento del innegable abrigo para los paseantes de la céntrica vía, por lo que su propuesta concentró los derribos en los soportales de la línea oriental o de los impares, tal como se aprobó definitivamente en 1871. Todas estas circunstancias están detalladamente relatadas en A. Rosende Valdés, "La rúa do Vilar y el proyecto de transformación de la trama decimonónica compostelana", en Mirando a Clío. El arte español reflejo de su historia, Actas del XVIII Congreso CEHA, Universidade de Santiago de Compostela, 2012, pp. 2772-2793; y para la evolución local de lo que este mismo autor ha definido como "cruzada contra el soportal": Rosende Valdés, Compostela 1780-1907... pp. 83-101.

${ }^{143}$ AHUS. Fondo municipal. Libros de actas municipales. Año 1937, sesión del 23 de octubre, fol. 565. La medida, decisiva para conservar "el ambiente único de Compostela", se encuentra destacada también en Rosende Valdés, "La rúa do Vilar...", pp. 2778-2779; y del mismo Compostela 1780-1907..., p. 137. Sin embargo, alguna publicación anterior equivoca la fecha del cambio normativo, como la de octubre de 1935 que aporta J. Morenas AydiIlo, "La ciudad reconstruida en el XIX" en Santiago de Compostela: la ciudad histórica como presente, C. Martí Arís, ed., Consorcio de Santiago, 1995, pp. 108-122. 